\title{
MAPEAMENTO DE QTLS NO CROMOSSOMO 1 DE Gallus gallus QUE INFLUENCIAM CARACTERÍSTICAS DE DESEMPENHO E CARCAÇA
}

\author{
KÁTIA NONES
}

Tese apresentada à Escola Superior de Agricultura "Luiz de Queiroz", Universidade de São Paulo, para obtenção do título de Doutor em Agronomia, Área de Concentração: Ciência Animal e Pastagens.

PIRACICABA

Estado de São Paulo - Brasil

Julho - 2004 


\section{MAPEAMENTO DE QTLS NO CROMOSSOMO 1 DE Gallus gallus QUE INFLUENCIAM CARACTERÍSTICAS DE DESEMPENHO E CARCAÇA}

\section{KÁTIA NONES}

Engenheira Agrônoma

Orientador: Prof. Dr. LUIZ LEHMANN COUTINHO

Tese apresentada à Escola Superior de Agricultura "Luiz de Queiroz", Universidade de São Paulo, para obtenção do título de Doutor em Agronomia, Área de Concentração: Ciência Animal e Pastagens.

PIRACICABA

Estado de São Paulo - Brasil

Julho - 2004 
Dados Internacionais de Catalogação na Publicação (CIP)
DIVISÃO DE BIBLIOTECA E DOCUMENTAÇÃO - ESALQ/USP

\begin{abstract}
Nones, Kátia
Mapeamento de QTLs no cromossomo 1 de Gallus gallus que influênciam características de desempenho e carcaça / Kátia Nones. -- Piracicaba, 2004. 110 p. : il.

Tese (doutorado) - - Escola Superior de Agricultura Luiz de Queiroz, 2004. Bibliografia.
\end{abstract}

1. Carcaça 2. Galinha 3. Mapeamento cromossômico 4. Marcador molecular I.Título

CDD 636.5

"Permitida a cópia total ou parcial deste documento, desde que citada a fonte - 0 autor" 
Dedico aos meus pais,

Eliana M. Nones e Lauro Nones 


\section{AGRADECIMENTOS}

A Deus, por estar comigo.

Aos meus pais e irmãs, pelo apoio, carinho, amizade e dedicação em todas as horas. À pesquisadora Mônica Corrêa Ledur pela amizade, orientação e confiança.

Ao professor Luiz Lehmann Coutinho pela oportunidade e pelos ensinamentos valiosos ao longo do curso.

À Escola Superior de Agricultura Luiz de Queiroz, em especial ao Departamento de Zootecnia, pela oportunidade da realização deste curso.

Aos colegas de laboratório pela amizade e paciência.

Aos funcionários da ESALQ que direta ou indiretamente contribuíram para a realização desta pesquisa.

À FAPESP - Fundação de Amparo à Pesquisa do Estado de São Paulo pelo apoio financeiro. 


\section{SUMÁRIO}

Página

LISTA DE SIGLAS ….................................................................. vii

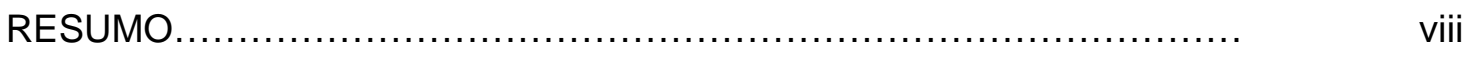

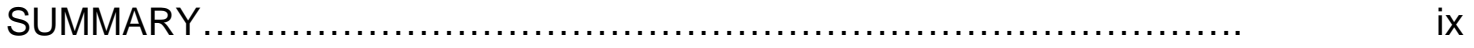

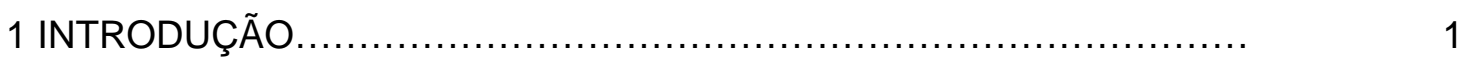

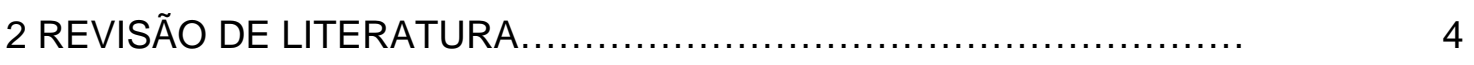

2.1 Marcadores microssatélites...........................................................

2.2 Mapa de ligação............................................................

2.3 Genoma da galinha (Gallus gallus) e o Mapa Consenso................ 8

2.4 População para mapeamento mapeamento de QTLs................... 11

2.5 Genotipagem Seletiva................................................... 12

2.6 Mapeamento de QTLs.................................................... 15

2.7 Intervalo de confiança............................................. 20

2.8 Nível de significância genômico ..................................................... 21

2.9 Mapeamento de QTLs em outras populações................................... 23

2.10 Seleção Assistida por Marcadores (MAS) .................................... 27

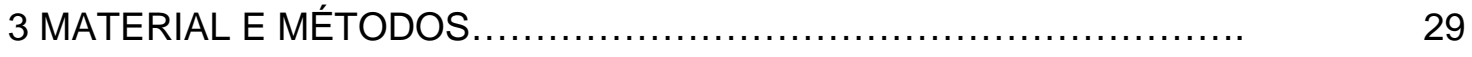

3.1 População experimental.......................................... 29

3.2 Coleta dos dados fenotípicos e de sangue das aves................... 32

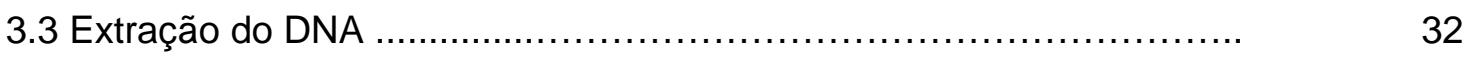

3.4 Escolha dos marcadores microssatélites.......................... 33

3.5 Amplificação por PCR ................................................ 35

3.6 Seleção de marcadores informativos.................................. 36

3.7 Genotipagem seletiva........................................................

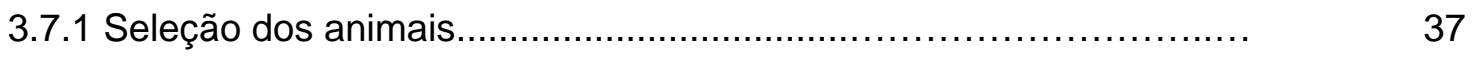




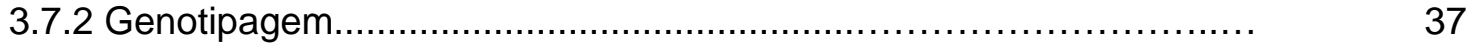

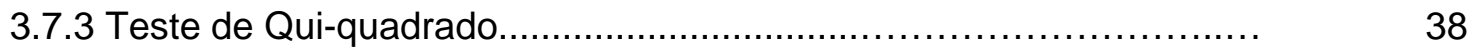

3.8 Genotipagem Completa …............................................... 39

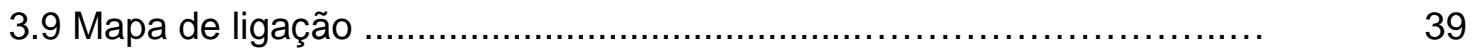

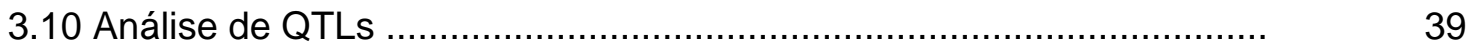

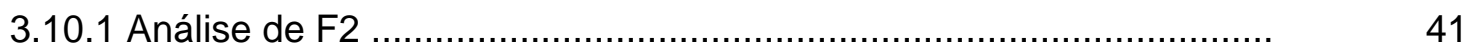

3.10.2 Análise de meio-irmãos paternos ………….............................. 42

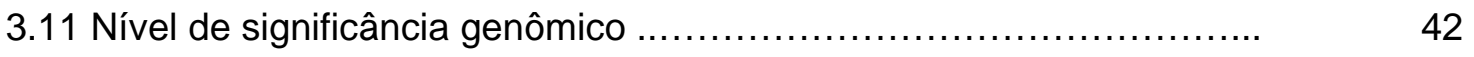

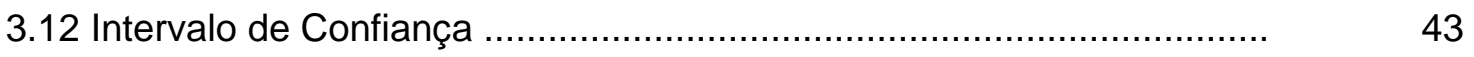

4 RESULTADOS E DISCUSSÃO …...................................

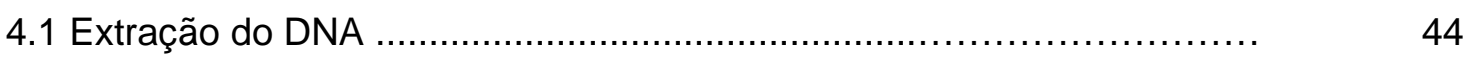

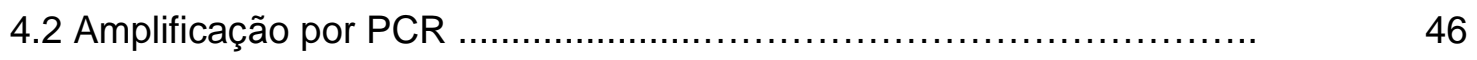

4.3 Seleção de marcadores informativos e genotipagem.......................... 51

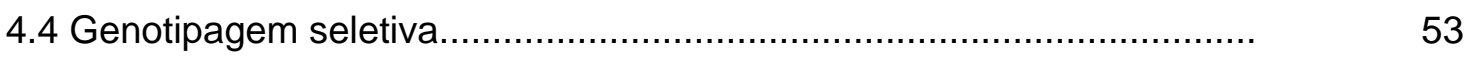

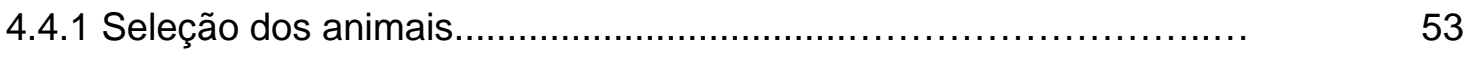

4.4.2 Genotipagem ...................................................... 55

4.4.3 Teste de Qui-quadrado ………………………......................... 56

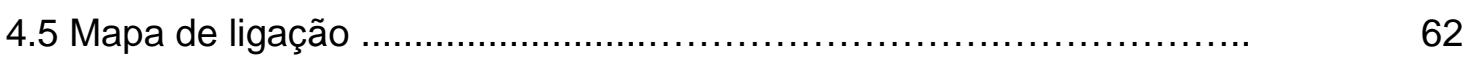

4.6 Mapeamento de QTLs............................................... 67

4.6.1 Mapeamento de QTLs - Análise de F2 .............................

4.6.2 Mapeamento de QTLs - Análise de meio-irmãos paternos .............. 78

4.7 Intervalo de Confiança ...................................................................

4.8 Comparação dos QTLs mapeados com a genotipagem seletiva ......... 90

4.9 Considerações finais e implicações ..................................................... 92

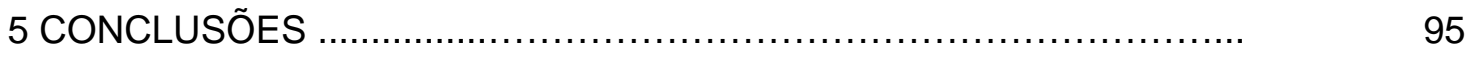

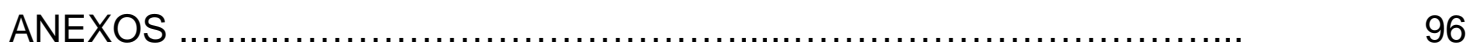

REFERÊNCIAS BIBLIOGRÁFICAS ...................................... 


\section{LISTA DE SIGLAS}

QTL - Quantitative Trait Loci - Locos controladores de características quantitativas

RFLP - Restriction Fragment Length Polymorphism - Polimorfismo no comprimento de fragmentos de restrição

RAPD - Random Amplified Polymorphic DNA - Polimorfismo de DNA amplificado ao acaso

AFLP - Amplified Fragment Length Polymorphism - Polimorfismo de comprimento de fragmentos amplificados

SNPs - Single nucleotide polymorphisms - Polimorfismo de um nucleotídeo

$\mathrm{cM}$ - centiMorgan

MAS - Marker Assisted Selection - Seleção auxiliada por marcadores 


\title{
MAPEAMENTO DE QTLS NO CROMOSSOMO 1 DE Gallus gallus QUE INFLUENCIAM CARACTERÍSTICAS DE DESEMPENHO E CARCAÇA
}

\author{
Autora: KÁTIA NONES \\ Orientador: Prof. Dr. LUIZ LEHMANN COUTINHO
}

\section{RESUMO}

Uma população experimental $\mathrm{F} 2$ foi desenvolvida a partir do cruzamento de uma linhagem macho de frangos de corte com uma linhagem de postura, com o objetivo de mapear QTLs (locos controladores de características quantitativas) para características de desempenho e carcaça. Um total de 2.063 animais F2 em 21 famílias de irmãos completos obtidas em 17 incubações. As aves foram criadas como frangos de corte e abatidas a 6 semanas de idade, foram avaliadas 19 características de desempenho e carcaça. A genotipagem foi realizada em 3 fases: 1) Um total de 80 marcadores microssatélites do cromossomo 1 foram testados nos indivíduos parentais e F1 para identificar marcadores informativos. 2) Genotipagem seletiva dos indivíduos F2 que representam os extremos fenotípicos para peso vivo aos 42 dias de idade (P42), para identificar regiões potencialmente associadas $(P<0,10)$ com esta característica. 3) Sete famílias de irmãos completos (649 F2) foram genotipados para 12 marcadores associados na fase 2 e para 14 marcadores flanqueadores. Mapeamento por intervalo utilizando regressão foi aplicado para dois modelos genéticos (F2 e meio-irmãos) para detectar QTLs Foram encontradas fortes evidências de QTLs afetando peso vivo, consumo de ração, conversão alimentar e peso de asas, coxas e sobrecoxas, peito, gordura abdominal, fígado, pulmão e coração no cromossomo 1. 


\title{
MAPPING QTLS ON CHICKEN CHROMOSOME 1 AFFECTING PERFORMANCE AND CARCASS TRAITS
}

\author{
Author: KÁTIA NONES \\ Adviser: Prof. Dr. LUIZ LEHMANN COUTINHO
}

\section{SUMMARY}

An F2 chicken population was developed by crossing a broiler sire line and a layer line, with the objective of mapping Quantitative Trait Loci (QTL) for performance and carcass traits. A total of 2,063 F2 chicks in 21 full-sib families from 17 hatches were reared as broilers and slaughtered at 6 weeks of age. Nineteen performance and carcass quality traits were measured. The genotyping was done in three phases: 1) A total of 80 microsatellite markers from chromosome 1 were tested in the parental and F1 individuals to identify informative markers. 2) Selective genotyping of F2 individuals, representing extreme phenotypes for body weight at 42 days of age (BW42), to identify regions potentially associated $(P<0,10)$ with this trait. 3$)$ Seven full-sib families $(649$ F2 chicks) were genotyped for 12 markers associated in phase 2 and for additional 14 flanking markers. Interval mapping using regression methods was applied to two different genetic models: 1) Line-cross; 2) Half-sib analyses for mapping QTL. Strong evidences for QTL affecting body weight, feed intake, feed conversion and weights of drums and thighs, breast, abdominal fat, liver, lung and heart were found on chromosome 1. 


\section{INTRODUÇÃO}

Nas últimas décadas a avicultura tem se tornado altamente tecnificada e ocupa lugar de destaque dentro da agropecuária brasileira, alcançando altos índices de desempenho na produção de carne e ovos. O Brasil ocupa atualmente o segundo lugar como produtor e exportador de carne de frango. No ano de 2002 foram produzidas para o mercado interno 5.917.000 toneladas de carne de frango e foram exportadas 1.599.923 toneladas, totalizando 7.516.923 toneladas. O consumo de carne de frango no Brasil teve um aumento considerável nos últimos anos, passando de 15,74 kg/habitante/ano em 1992 para 33,3 kg/habitante/ano em 2003 que foi muito superior a média do consumo mundial de 8,4 kg/habitante/ano (www.abef.com.br).

A avicultura de postura também vem se desenvolvendo, mas em ritmo bem mais lento. A produção de ovos cresceu consideravelmente nos últimos anos em todo mundo (54\%), porém no Brasil o crescimento foi de apenas 8,8\% entre 1990 e 2001. Este fato se deve ao baixo consumo (94 ovos/habitante/ano) no Brasil comparado com o México que consome cerca de 300 ovos/habitante/ano (Beterchini, 2003).

Nas últimas décadas a produção de ovos (em número de ovos/galinha/ano) aumentou cerca de 3 vezes e a taxa de crescimento em frangos de corte (em dias para alcançar $1,5 \mathrm{~kg}$ ) aumentou 4 vezes. Entretanto, associadas a essas melhorias das características de produção através do melhoramento tradicional, surgiram algumas respostas correlacionadas indesejáveis, como o aumento de doenças metabólicas, carne de baixa qualidade (PSE - pale, soft, exsudative: pálida, flácida e exsudativa), redução da fertilidade, queda na resposta vacinal e redução da resistência a doenças infecciosas, em aves de corte, e aumento da incidência de osteoporose e problemas na qualidade da casca do ovo em poedeiras (Burt, 2002). Segundo este autor, a genética molecular pode melhorar estas características sem prejudicar os ganhos já obtidos nas características de produção, pois com o uso de ferramentas moleculares é possível identificar genes que controlam características quantitativas de importância 
econômica auxiliando e acelerando programas de melhoramento animal, principalmente para características difíceis de serem medidas, de alto custo de avaliação, de baixa herdabilidade ou limitadas pelo sexo.

A partir de tecnologias de DNA recombinante e da reação em cadeia da polimerase ("Polimerase Chain Reaction" - PCR), diferentes técnicas foram desenvolvidas permitindo a identificação de vários tipos de marcadores moleculares distribuídos ao longo do genoma em várias espécies, possibilitando que eles sejam associados a características quantitativas e assim utilizados futuramente na seleção assistida por marcadores (Marker Assisted Selection - MAS).

Um mapa consenso do genoma de aves construído a partir dos mapas de ligação de 3 populações (Compton, East Lansing e Wageningen) foi publicado por Groenen et al. (2000), apresentando um total de 1889 marcadores cobrindo $3800 \mathrm{cM}$ do genoma. Atualmente (26/05/2004), existem 2.522 locos posicionados no mapa de ligação da galinha, dos quais 757 são genes (ARKdb:http://www.thearkdb.org/).

Ao longo do mapa consenso encontram-se marcadores microssatélites distribuídos a intervalos regulares que permitem estudos para a identificação de locos que controlam características quantitativas (QTLs) de importância comercial. Para o mapeamento de QTLs deve-se estudar a relação destes marcadores microssatélites com características fenotípicas de interesse em populações planejadas exclusivamente para este fim, através do cruzamento de linhagens divergentes que estejam segregando para as características de interesse, utilizando um delineamento apropriado.

Em aves alguns QTLs já foram encontrados, entretanto, antes da utilização desses resultados na MAS, há necessidade de validação dos mesmos em outras populações experimentais e comerciais visando confirmar as suas localizações e seus efeitos sobre as características. No cromossomo 1 alguns QTLs para características de carcaça e desempenho já foram mapeados, como por exemplo, peso vivo, consumo de ração e deposição de gordura. Entretanto novos estudo para confirmar estes achados em outras populações e mapear QTL para novas características de importância econômica são necessários.

A partir de QTLs mapeados será possível encontrar genes situados nestas regiões que apresentem efeitos nas características quantitativas de interesse. Isso 
pode contribuir para uma seleção mais precoce ou econômica dependendo da característica avaliada.

A Embrapa Suínos e Aves, em conjunto com a Escola Superior de Agricultura Luiz de Queiroz (ESALQ/USP), iniciaram estudos em genômica de aves no Brasil em 1999, cujos objetivos do projeto são mapear novos QTLs e confirmar algumas regiões já associadas a características de produção em outras populações. Para isso foi desenvolvida uma população F2 específica para estudos genômicos a partir do cruzamento recíproco de linhagens divergentes de corte e postura, que serão utilizadas para identificar marcadores associados a características de crescimento, consumo e composição de carcaça, em nossas condições de clima e manejo.

Este estudo tem como objetivos construir um mapa de ligação do cromossomo 1 da galinha e mapear QTLs neste cromossomo para características de desempenho e carcaça, na população desenvolvida pela Embrapa Suínos e Aves utilizando marcadores microssatélites. 


\section{REVISÃO DE LITERATURA}

Nos últimos anos, grandes avanços têm sido feitos na genética molecular e quantitativa. Vários genes e proteínas têm sido identificados e estudados, permitindo entender como eles afetam o desenvolvimento, crescimento e metabolismo de animais e plantas. Novas metodologias na genética quantitativa estão sendo usadas na dissecação de características quantitativas, identificando regiões no genoma que influenciam estas características (QTLs) e, para posteriormente identificar os genes presentes nestas regiões que estejam causando este efeito (Liu, 1998).

A genética molecular e a genética quantitativa, além de auxiliar na identificação e no entendimento do complexo funcionamento de genes que controlam as características quantitativas, geram informações que podem ser usadas para implementar estratégias de melhoramento através da seleção assistida por marcadores (MAS). Esta pode ser utilizada em conjunto com a seleção fenotípica, na introgressão de determinada característica de uma população para outra, mantendo as características desejáveis da população receptora e também na predição do desempenho e heterose da progênie resultante de cruzamentos. A genética molecular também pode ser aplicada para identificação de parentesco e, em programas de conservação genética, identificar populações genéticas únicas e quantificar a diversidade genética (Dekkers \& Hospital, 2002).

Segundo Burt (2002) a biotecnologia não trará grandes ganhos genéticos para as características de produção devido ao limite biológico, que será alcançado em aproximadamente 20 anos. Contudo, a indústria avícola precisa se adaptar às novas exigências do mercado consumidor, bem como reduzir os custos de produção. Para isso, precisa melhorar características que são difíceis de serem selecionadas pelos métodos convencionais e é nessa situação que a genética molecular poderá trazer sua maior contribuição. Hoje o maior gasto na produção de aves é com a alimentação e a seleção para a melhoria da conversão alimentar pode ser uma opção para a redução 
de custos. Em aves de postura há problemas de osteoporose e qualidade da casca do ovo que são outros pontos que vão se beneficiar da genética molecular. A seleção para aumento da resistência a doenças também pode reduzir gastos com vacinas e antibióticos. Alguns desses fatores também afetam o bem-estar animal, que juntamente com a qualidade da carne e segurança alimentar são exigências da legislação sanitária e do mercado consumidor, que também poderão se beneficiar dos estudos utilizando marcadores moleculares.

\subsection{Marcadores Microssatélites}

Com o uso de marcadores moleculares é possível identificar genótipos antes que as características se manifestem e, com isso, acelerar o processo de seleção. Também poderão auxiliar na seleção de animais para características que não podem ser avaliadas no animal vivo, que sejam dependentes do sexo ou de alto custo de avaliação ou ainda para características de baixa herdabilidade.

Existem vários tipos de marcadores moleculares, tais como isoenzimas, AFLP, RAPD, RFLP, microssatélites e SNPs. Cada um deles tem suas vantagens e desvantagens, sendo que alguns se mostram mais eficientes em relação a outros, principalmente sob o aspecto de repetibilidade ou em relação à característica de dominância (Ferreira \& Grattapaglia, 1998). A escolha do tipo de marcador a ser utilizado vai depender dos objetivos do estudo a ser realizado, levando em conta as vantagens e desvantagens de cada marcador.

Marcadores do tipo microssatélites são pequenas seqüências, com 1 a 4 nucleotídeos, repetidas em tandem e distribuídas ao longo do genoma. Elas podem ser amplificadas por PCR utilizando-se um par de "primers" específicos complementares a seqüências que flanqueiam o microssatélite. Estes marcadores diferem entre si pelo número de repetições e composição de nucleotídeos, formando sítios altamente variáveis (polimórficos), que é um ponto importante para a análise genética, pois permite amostrar simultaneamente um grande número de locos polimórficos no genoma (Ferreira \& Grattapaglia, 1998).

Microssatélites são marcadores codominantes, ou seja, ambos os alelos de um indivíduo heterozigoto são visualizados. São também marcadores multialélicos, ou seja, numa população vários alelos de um loco podem ser detectados e discriminados. 
Por estas razões são marcadores que possuem um maior conteúdo de informação de polimorfismo (PIC - Polymorphism Information Content, Ferreira \& Grattapaglia, 1998). Por isso este tipo de marcador é o mais utilizado no mapeamento de QTLs em animais de produção em que as linhagens não são endogâmicas e os animais podem ser heterozigotos e ainda diferentes indivíduos dentro de cada linhagem podem ter diferentes alelos de um mesmo loco.

Segundo Andersson \& Georges (2004) a utilização de SNPs no futuro poderá aumentar o número de marcadores no mapeamento de QTLs, no entanto eles ainda têm um alto custo de genotipagem o que limita seu uso. Entretanto, podem ser uma opção para refina o mapeamento de QTLs importantes.

\subsection{Mapa de Ligação}

O mapa de ligação permite estudar a arquitetura genética de características quantitativas, ou seja, identificar, mapear e medir a magnitude do efeito dos principais fatores genéticos envolvidos no controle destas características (Ferreira \& Grattapaglia, 1998).

A base genética para a construção de um mapa de ligação é a recombinação genética resultante do "crossing-over" entre cromossomos homólogos durante a meiose. A recombinação é medida pela fração de recombinação, que é a razão de gametas recombinantes pelo total de gametas. Geralmente, ela ocorre ao acaso nos cromossomos. A recombinação entre diferentes locos é associada significativamente com a distância física entre eles. É esperado que dois locos muito distantes num cromossomo tenham maiores chances de se recombinarem. A fração de recombinação não é aditiva ao longo do cromossomo, mas a aditividade aumenta com a distância entre locos. Esta inferência é o fundamento do mapeamento genético. Entretanto, a relação entre recombinação e distância física varia de organismo para organismo (Liu, 1998).

A construção de um mapa de ligação envolve a criação de uma população segregante a partir de duas linhagens progenitoras, identificação dos genótipos de vários marcadores no genoma e a utilização de diversas metodologias de análise estatística e computacional para estimar ligação e distância entre marcadores. 
Para gerar um mapa de ligação é necessário avaliar o padrão de segregação dos alelos dos marcadores individualmente em uma população, detectar desequilíbrio de ligação entre marcadores juntamente com a determinação da distância entre locos e o ordenamento dos mesmos em grupos de forma linear (Liu, 1998).

Desequilíbrio de ligação é qualquer desvio das freqüências alélicas dos locos em relação às freqüências esperadas sob a hipótese destes não estarem ligados e segregando independentemente, indicando ligação entre os locos. Se eles estiverem ligados, passarão em conjunto para a próxima geração (Falconer \& Mackay, 1996).

Para obter as frações de recombinação é necessário um número grande de meioses informativas. Para isso, uma grande população necessita ser genotipada para identificar ligação entre os marcadores localizados no mesmo grupo de ligação. O espaçamento entre marcadores, quando muito pequeno, dificulta o ordenamento dos locos pela dificuldade de se obter recombinação.

A distância entre locos pode ser expressa em porcentagem de recombinação ou traduzida em centiMorgans (cM) através da utilização de diferentes funções de mapeamento (Haldane, 1919; Kosambi, 1944; Crow, 1990). Essas funções são utilizadas para a correção de distâncias calculadas em porcentagem de recombinação para distâncias calculadas em cM, levando em conta, ou não, o fenômeno da interferência, que ocorre quando um "crossing over" em uma região interfere na ocorrência de mesmo fenômeno em uma região adjacente (Liu, 1998).

Um centiMorgan equivale aproximadamente a 1\% de recombinação quando os marcadores estão bem próximos, mas pode diferir consideravelmente da porcentagem de recombinação quando os marcadores estão mais distantes. Isso ocorre por causa do aumento da probabilidade de "crossing over" duplos e triplos, que podem influenciar a estimativa da proporção de genótipos recombinantes em relação a genótipos parentais (Ferreira \& Grattapaglia, 1998).

Weir (1996) e Ferreira \& Gratapaglia (1998) chamam atenção para dois problemas na determinação da ordem correta de um conjunto de genes ou marcadores. Primeiro, como somente as estimativas dos coeficientes de recombinação destes locos são conhecidas, a melhor ordem por este critério pode não ser a verdadeira, simplesmente por efeito de amostragem (amostra muito pequena). Segundo, quando a análise envolve um grande número de locos o número de ordens possíveis pode tornar-se impraticável. 
Métodos estatísticos utilizando estimativas de máxima verossimilhança da freqüência de recombinação entre marcadores, juntamente com algoritmos de ordenação rápidos para um grande número de marcadores têm sido utilizados para a construção de mapas genéticos. Os métodos de máxima verossimilhança basicamente estimam o valor do parâmetro (freqüência de recombinação) que maximiza a probabilidade de obtenção dos dados genotípicos (Liu, 1998).

Lynch \& Walsh (1998) afirmam que não existe uma relação universal entre distância de mapeamento (cM) e o tamanho físico do fragmento de DNA (em pares de bases), pois um cM pode variar de 10.000 a 1.000 .000 de pares de bases, dependendo da espécie, podendo também existir grandes diferenças entre segmentos de um mesmo cromossomo.

\subsection{Genoma da galinha (Gallus gallus) e o Mapa Consenso}

O genoma da galinha é formado por 38 pares de cromossomos autossômicos e o par de cromossomos sexuais $Z$ e W, sendo a fêmea o sexo heterogamético $(Z W)$ e o macho o homogamético (ZZ). Os cromossomos podem ser divididos em 9 macrocromossomos e 30 microcromossomos, sendo esses últimos difíceis de serem diferenciados (Crooijmans, 2000).

Os microcromossomos representam cerca de $30 \%$ do genoma da galinha, mas têm uma maior densidade de genes que os macrocromossomos (Smith et al., 2000). Segundo Primmer et al. (1997), seqüências microssatélites não estão distribuídas ao acaso no genoma e estão em menor densidade nos microcromossomos. Entretanto, resultados obtidos por Smith et al. (2000) discordam da afirmação anterior, pois obtiveram mais microssatélites do que o esperado nos microcromossomos, afirmando que o problema estava na técnica utilizada no estudo anterior. Este resultado possibilita a construção de mapas de ligação dos cromossomos e estudos de mapeamento de QTLs abrangendo todo o genoma da galinha.

Os mapas de ligação de 3 populações (C - Compton, E - East Lansing, W Wageningen), desenvolvidas a partir de linhagens divergentes foram utilizados para construir um mapa consenso do genoma da galinha, apresentando um total de 1889 locos distribuídos em 3800 cM (Groenen et al. 2000). Atualmente (29/05/04), existem 2.526 locos no mapa de ligação da galinha, dos quais 761 são genes (ARKdb: 
http://www.thearkdb.org/). Este mapa será em breve acrescido de um grande número de marcadores e genes com a conclusão do seqüenciamento do genoma da galinha em março de 2004 pela Washington University Genome Sequencing Center e o National Human Genome Research Institute nos Estados Unidos. A galinha foi o primeiro animal doméstico a ter seu genoma seqüenciado quase que na sua totalidade. A seqüência derivou de uma única fêmea da raça Red Jungle Fowl, que é a ancestral selvagem da galinha doméstica. Correções nesta versão serão incorporadas na seqüência do genoma na medida em que mais informações forem geradas. Esta seqüência será ainda complementada com o seqüenciamento do genoma de 3 raças de galinhas domésticas que vem sendo realizado pelo Beijing Genomics Institute, na China. A comparação das seqüências dessas 3 raças com a da Red Jungle Fowl e entre elas irá gerar uma coleção muito grande de polimorfismos genéticos, na sua maioria SNPs (polimorfismos de um único nucleotídeo) que poderão auxiliar no mapeamento de QTLS.

O mapa consenso fornece informações importantes sobre marcadores, pois ele pode ser utilizado como instrumento no momento da escolha de marcadores e para comparação do ordenamento destes em outras populações para o mapeamento de QTLS.

Como resultado de um enorme esforço de vários grupos de pesquisa, o mapa consenso da galinha está cada vez mais denso, com um maior número de marcadores distribuídos a intervalos regulares ao longo de todos os cromossomos, o que permite um mapeamento mais fino para a identificação de genes de importância comercial.

Informações detalhadas sobre as famílias utilizadas no mapa consenso e os marcadores disponíveis podem ser encontrados nas páginas do Chicken Genome Project da Michigan State University (http://poultry.mph.msu.edu/) e do Roslin Institute da Escócia (http://www.ri.bbsrc.ac.uk/chickmap/ChickMapHomePage.html). O mapa consenso do cromossomo 1 de aves que possui $565 \mathrm{cM}$ é apresentado na Figura 1 indicando os marcadores e genes já identificados. 


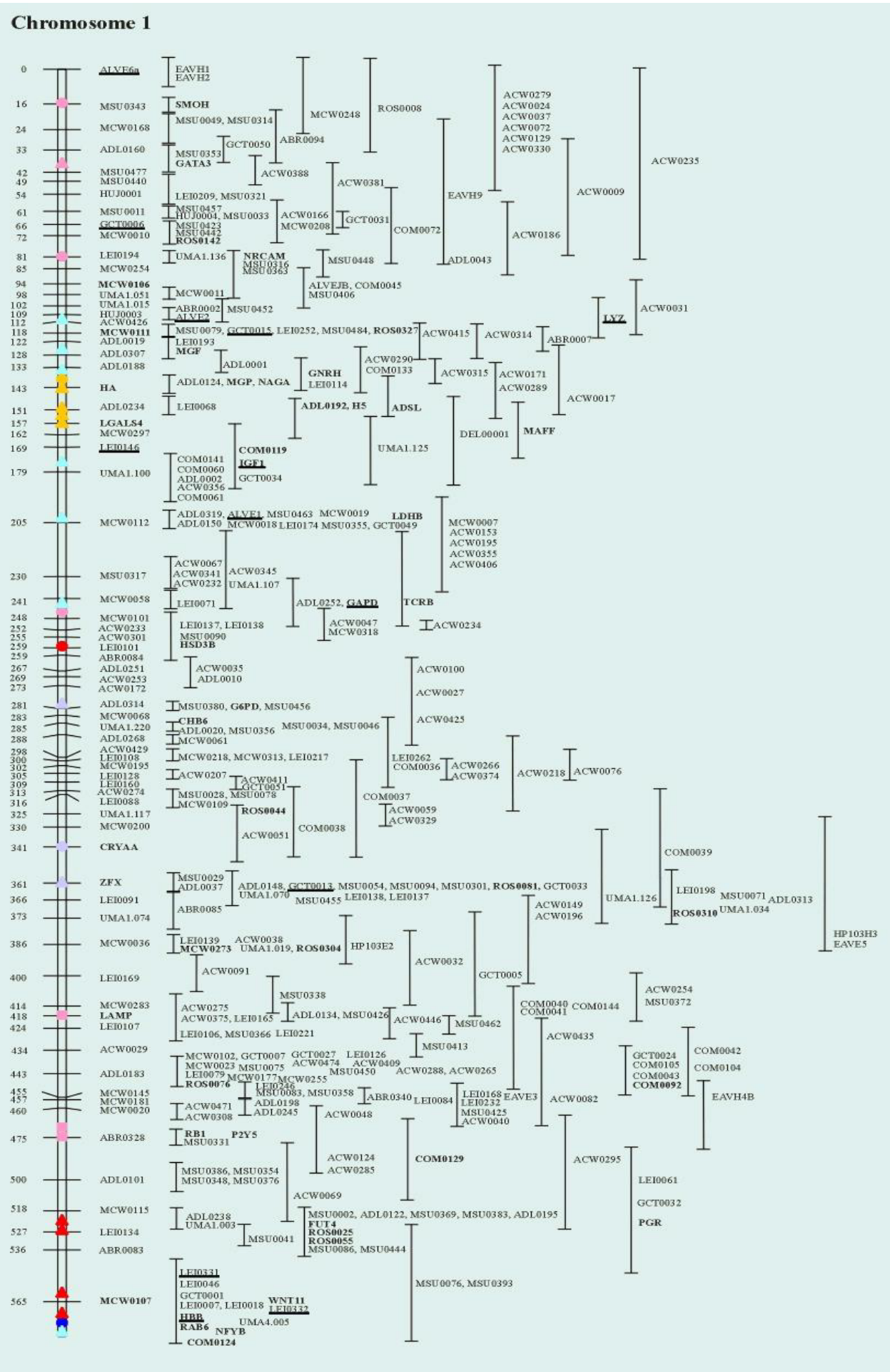

Figura 1 - Mapa consenso do cromossomo 1 de aves com os marcadores microssatélites e suas posições em cM. (http://poultry.mph.msu.edu/). Pontos coloridos indicam posições de genes localizados no cromossomo, por mapeamento comparativo com o genoma humano 


\subsection{População para mapeamento de QTLs}

Para criar uma população para o mapeamento de QTLs, as linhagens parentais devem ter variação tanto no DNA quanto fenotípica. Quanto mais variação no DNA, mais fácil encontrar marcadores informativos (polimórficos), que permitam traçar eventos de recombinação para o mapeamento de QTLs (Liu, 1998).

A população é criada a partir da escolha de parentais, dos quais desenvolve-se uma progênie com centenas de indivíduos para obter um número suficientemente grande de eventos meióticos, que possibilite estimar a freqüência de recombinação genética entre os marcadores. Esta população é genotipada para algumas dezenas de marcadores, inicialmente selecionados por serem polimórficos (que permitam detectar alelos diferentes entre as linhagens parentais), distribuídos a intervalos regulares (10 a 30cM) no genoma (Ferreira \& Grattapaglia, 1998).

O uso de marcadores moleculares para avaliar a variação de características quantitativas foi inicialmente desenvolvido para linhagens endogâmicas, mas para animais de produção não é possível obter linhagens completamente endogâmicas. Populações não endogâmicas possuem problemas adicionais que são teoricamente passíveis de serem superados pelo uso de um grande número de indivíduos necessários para caracterizar o QTL (Knott et al., 1998).

Zhu et al. (2001) apresentam alguns problemas encontrados no mapeamento de QTLs quando se utiliza linhagens não endogâmicas: 1) Os alelos do QTL podem não estar fixados nas linhagens, e assim reduzir o poder de detecção de QTL, 2) as fases de ligação entre QTL e marcadores podem variar entre indivíduos dentro da linhagem, por isso a associação entre QTL e marcadores deve ser feita dentro de família e 3) a análise estatística é mais laboriosa, pois até 4 alelos podem estar segregando nos locos do QTL e dos marcadores para cada família.

Em populações não endogâmicas são necessárias 3 gerações para distinguir os possíveis diferentes alelos e estabelecer a fase de ligação dos alelos dos marcadores nas diferentes famílias e assim determinar os eventos de recombinação (Liu, 1998). Uma possibilidade para a utilização de populações não endogâmicas visando a detecção de QTLs é a escolha de linhagens parentais fenotipicamente contrastantes para as características de interesse, com o objetivo de maximizar os efeitos de substituição alélica nos locos associados a características quantitativas, para 
que eles possam ser detectados. Recomenda-se a utilização de linhagens com uma distância genética considerável, pois quanto mais próximas as linhagens mais difícil a obtenção de polimorfismo (Ferreira \& Grattapaglia, 1998).

Para o mapeamento de QTLs em populações não endogâmicas parte-se do princípio que as linhagens são homozigotas para alelos alternativos nos QTLs e polimórficas com relação aos marcadores. Muitas vezes uma avaliação prévia das linhagens deve ser realizada para que se obtenha as informações necessárias para a escolha dos parentais adequados (Liu, 1998). Os indivíduos dentro de linhagens não endogâmicas podem ser diferentes genética e fenotipicamente. Segundo Crooijmans et al. (1996), os marcadores podem ser altamente informativos em uma linhagem e ser monomórficos em outra, o que enfatiza a necessidade de análises preliminares do nível de polimorfismo dos marcadores para a escolha de indivíduos informativos para a criação de populações que permitam o mapeamento de QTLs.

De acordo com Hillel (1997) e Zhu et al. (2001), é recomendável uma genotipagem prévia dos animais das linhagens para a escolha dos progenitores da população de mapeamento. Se isso não for feito, os autores sugerem a genotipagem da geração F1 para a escolha das famílias mais informativas que terão a sua progênie F2 genotipada para o mapeamento de QTLs. Segundo Zhu et al. (2001), populações não endogâmicas têm um grande número de locos não informativos, o que pode reduzir o poder de detectar QTLs além do aumento do custo do projeto.

\subsection{Genotipagem Seletiva}

Segundo Lander \& Botstein (1989) e Darvasi \& Soller (1992), a genotipagem seletiva ("selective genotyping") é uma estratégia que pode reduzir significativamente o número de indivíduos genotipados para um dado poder de detecção de QTLs a partir de um grande número de indivíduos fenotipados. O termo genotipagem seletiva é usado quando se determina a ligação entre os locos dos marcadores e locos que controlam a característica quantitativa, genotipando somente os indivíduos presentes no extremo superior e inferior da distribuição normal dos fenótipos de uma grande população. Essa metodologia dispensa a genotipagem de todos os indivíduos para todos os marcadores e permite uma análise preliminar indicando marcadores que, possivelmente, estejam associados a QTLs. Os marcadores significativamente 
associados a QTLs nesta análise preliminar podem ser utilizados na análise de intervalos juntamente com marcadores flanqueadores.

Lander \& Botstein (1989) afirmaram que indivíduos de uma parte da progênie contribuem mais para a informação de ligação do marcador com o QTL que outros. Como um princípio geral, os indivíduos que fornecem maior informação são aqueles cujo genótipo pode ser claramente inferido do seu fenótipo, ou seja, os animais com fenótipos extremos contribuem com maior informação de ligação que os animais concentrados próximos à média fenotípica da população. Progênies com valores fenotípicos de mais de 1 desvio-padrão da média compreendem cerca de 33\% de toda a população e contribuem com cerca de $81 \%$ de toda a informação de ligação. Quando a população é grande e genotipa-se apenas os extremos, pode-se reduzir em até 5,5 vezes o número de indivíduos genotipados com a mesma informação de ligação.

Darvasi \& Soller (1992) afirmam que a partir de uma população de 500 indivíduos e genotipando-se a metade $(p=0,5)$ o poder de detecção de QTL é reduzido de 0,8 para 0,77 . Este resultado significa que metade da população pouco contribui com informação para a análise, e quando o tamanho da população é grande uma proporção muito menor da população pode ser selecionada.

Segundo Darvasi \& Soller (1992) a proporção ótima de indivíduos a serem genotipados do ponto de vista de minimizar custos para um dado poder experimental depende da relação entre o custo da genotipagem completa de um indivíduo para todos os marcadores incluídos no experimento e o custo da fenotipagem. O número de animais selecionados para a genotipagem seletiva nunca deverá ser maior que 50\% da população ( $25 \%$ de cada extremo). A proporção ideal de seleção dos extremos depende da espécie e do custo de genotipagem. No caso de grandes animais recomenda-se uma proporção ótima de seleção de 10 a 40\%. Para pequenos animais (como por exemplo, em aves), a proporção ótima de seleção pode estar entre 5 e 10\%.

Em uma população não endogâmica o valor fenotípico de cada indivíduo é dependente do efeito de família e de efeitos ambientais e a interação entre esses fatores. Se os indivíduos são escolhidos nos extremos da população, muitos indivíduos de algumas famílias podem ser escolhidos em detrimento de indivíduos de outras famílias, apenas por causa do efeito de família (Muranty et al., 1997). De acordo com Falconer \& Mackay (1996), é melhor ter o máximo de famílias representadas, pois quando se tem um alelo de efeito principal representado poucas vezes pode-se 
detectar um QTL, porém quando se tem um alelo de efeito menor e se perde alguma família em que ele esteja presente pode-se não detectar o QTL.

Segundo Moody et al. (1999) e Bovenhuis \& Spelman (2000) em populações não endogâmicas a genotipagem seletiva deve ser feita dentro de famílias de irmãoscompletos para eliminar efeitos que podem ser atribuídos ao composição genética específica de uma determinada combinação de pai e mãe.

Lander \& Bostein (1989), Darvasi \& Soller (1992), Muranty et al. (1997) e Bovenhuis \& Spelman (2000) afirmam que ao se aplicar a estratégia de genotipagem seletiva pode-se aumentar significativamente o poder de detecção de QTLs para a característica pela qual os indivíduos foram selecionados. Entretanto, estudos de detecção de QTLs geralmente utilizam várias características e o benefício da redução de genotipagens diminui com o aumento no número de características a serem estudadas, especialmente se a correlação entre elas for baixa. Quando as características não são correlacionadas, os extremos fenotípicos das características podem ser diferentes, podendo-se ter uma redução no poder estatístico para detectar QTLs para algumas características, contudo, o poder de detecção de QTL é levemente reduzido se as características são altamente correlacionadas.

Segundo Bovenhuis \& Spelman (2000), o poder de detecção de QTLs afetando características correlacionadas pode ser considerável, sendo possível aplicar a genotipagem seletiva corretamente a partir da distribuição normal de apenas uma característica mesmo quando se tem interesse em múltiplas características correlacionadas.

Yonash et al. (2001) analisaram 2 linhagens de frangos de corte divergentemente selecionadas para alta e baixa resposta imune a E. coli. Para a genotipagem seletiva foram selecionados indivíduos com os $20 \%$ maiores e menores valores para resposta imune a $E$. coli dentro da família de mãe. Para as demais características avaliadas no estudo a seleção dos extremos foi considerada como sendo ao acaso, devido à baixa correlação entre as características. Os autores esperavam uma redução no poder de detectar QTLs para estas características, mas alguns QTLs foram confirmados na genotipagem completa.

Segundo Muranty et al. (1997), a genotipagem seletiva pode detectar QTLs de pequeno efeito. Em seu estudo foram selecionados 100 indivíduos dos extremos de uma população de 600 indivíduos para uma característica Y. Um QTL com efeito de 
$5 \%$ na característica $Y$ tem, segundo os autores, mais de $60 \%$ de chances de ser detectado na genotipagem seletiva, mas para um QTL com o mesmo efeito em uma característica $Z$ (não correlacionada com Y), as chances de detectá-lo são menores que $20 \%$.

Hillel (1997) sugere que uma estratégia eficiente para a identificação de QTL está baseada numa combinação de um teste de menor poder estatístico para a existência de ligação entre o marcador e o QTL (análise de marca simples) e um teste genético apropriado para a discriminação entre uma ligação verdadeira ou falsa.

Moody et al. (1999) e Ohno et al. (2000) utilizaram o teste de Qui-quadrado, como análise preliminar, para identificar marcadores possivelmente associados a QTLs. O teste foi aplicado para a hipótese de iguais freqüências alélicas nos grupos com maior e menor fenótipos, que são esperadas sob a hipótese nula do marcador não estar ligado ao QTL. Os marcadores identificados como ligados a QTLs, pelo teste de Qui-quadrado, e marcadores flanqueando essas regiões foram genotipados em toda a população para a realização de um teste genético (mapeamento por intervalo) para confirmar a associação de marcadores com QTLs.

\subsection{Mapeamento de QTLs}

Segundo Falconer \& Mackay (1996), um QTL é um segmento do cromossomo que afeta determinada característica quantitativa, não sendo necessariamente um único gene.

A associação entre marcadores que estão segregando e valores fenotípicos da característica de interesse sugere que um gene controlando algum componente desta característica está localizado próximo a estes marcadores (Liu, 1998).

O princípio básico para a identificação de QTLs é que os marcadores moleculares devem estar ligados aos locos que controlam as características de interesse, para que na segregação esses marcadores sejam passados de uma geração para outra junto com o gene que afeta a característica em questão (Arús et al. 1993).

A identificação de QTLs por mapeamento do genoma só é possível se o marcador e o QTL estiverem em desequilíbrio de ligação, o que aumenta o poder do teste estatístico no momento de correlacionar o QTL com as características fenotípicas 
de interesse. Para garantir esse desequilíbrio de ligação, o uso de delineamento experimental envolvendo o cruzamento de linhagens divergentes e a formação de gerações F1 e F2 apresenta vantagens em relação a outros delineamentos (Van der Beek et al., 1995).

Segundo Falconer \& Mackay (1996), cruzamentos controlados visam maximizar o desequilíbrio de ligação permitindo acompanhar um dado alelo de interesse por meio de marcadores. Se houver uma diferença na média do fenótipo entre as classes genotípicas do marcador, pode-se inferir que existe um QTL ligado àqueles marcadores, ou seja, as classes genotípicas dos marcadores segregam em conjunto com os alelos de um QTL de interesse.

Falconer \& Mackay (1996) afirmam que o número de QTLs detectados é sempre subestimado, devido ao fato de que dois QTLs muito próximos podem aparecer como apenas um, se eles estiverem em associação (ligação entre alelos favoráveis a característica nos 2 locos), ou ainda não serem detectados se os QTLs estiverem ligados em repulsão (ligação entre alelo favorável em um loco e um desfavorável no outro).

Embora os genótipos do QTL não possam ser observados, os valores de efeito aditivo $(a)$ e de dominância $(d)$ podem ser estimados pelo contraste entre as médias dos indivíduos nas classes genotípicas dos marcadores (Liu, 1998).

Lander \& Botstein (1989) e Haley \& Knott (1992) apresentaram detalhes do mapeamento por intervalos explorando o intervalo entre dois marcadores para a evidência de presença de QTLs em populações endogâmicas. O método foi originalmente implementado usando máxima verossimilhança por Lander e Botstein (1989). Informações sobre os efeitos do QTL (efeitos $a$ e $d$ ) são condicionados ao genótipo dos marcadores que flanqueiam a região, ou seja, à distribuição dos fenótipos nas classes genotípicas dos marcadores.

Haley \& Knott (1992), demonstraram que uma análise de quadrados mínimos pode ser usada no mapeamento por intervalo, pois fornece teste estatístico e estimativas muito similares àqueles obtidos por máxima verossimilhança, permitindo usar modelos mais complexos e mais realistas com uma menor demanda computacional. Uma regressão múltipla é utilizada para ajustar $a$ e $d$ para cada posição do QTL testada entre dois marcadores, utilizando valores numéricos como 
coeficientes de $a$ e $d$. Este procedimento fornece estimativas para o efeito aditivo ( $a$ ) e de dominância $(d)$, bem como somas de quadrados e quadrados médios de regressão e desvios, permitindo, assim, a realização de testes de hipótese sobre $a$ e d. A posição que gerar o melhor ajuste do modelo (menor soma de quadrados de resíduos) fornece a posição mais provável do QTL e as melhores estimativas dos seus efeitos.

Segundo Haley et al. (1994), a desvantagem de utilizar máxima verossimilhança no mapeamento de intervalos é a sua complexidade computacional, que dificulta análises simultâneas de vários QTLs, interações entre QTLs, efeitos de QTLs não ligados e efeitos fixos. A vantagem de análises simultâneas é o seu potencial de remover tendências e aumentar o poder (pela redução da variância residual) da análise realizada.

O mapeamento por intervalo utilizando o modelo proposto por Haley \& Knott (1992) é computacionalmente muito eficiente e viabiliza a utilização de técnicas de bootstrap (Churchil \& Doerge, 1994) e permutação (Visscher et al. 1996) utilizadas para determinar o intervalo de confiança do QTL e o nível de significância genômico, respectivamente, sendo uma outra opção ao método de máxima verossimilhança.

Em populações originadas de cruzamento entre linhagens endogâmicas, os marcadores selecionados são todos heterozigotos na geração F1. Isto simplifica em muito a análise para marcadores codominantes, pois com somente um par de marcadores flanqueando o intervalo é possível obter informação sobre o QTL. Como na maioria das espécies de produção não é possível obter linhagens endogâmicas, Haley et al. (1994) desenvolveram uma metodologia para análise de cruzamentos de linhagens não endogâmicas, utilizando três gerações e múltiplos marcadores ligados para análise de QTLs. O método de análise de F2 (line-cross) assume que as linhagens utilizadas (cruzamento entre linhagens selecionadas divergentemente ou raças com diferentes histórias de seleção) podem estar segregando para os locos dos marcadores, mas assumido que as linhagens estão fixadas para alelos alternativos do QTL. Quando as linhagens cruzadas não tiverem alelos alternativos do QTL fixados, o poder de detecção de QTLs será muito reduzido e seus efeitos serão subestimados.

O modelo sugerido por Haley et al. (1994) "line-cross analysis" (F2) foi criado a partir de populações F2 com grupos de irmãos completos ("full-sib") e meio-irmãos 
("half-sib"). O uso conjunto da informação de famílias meio-irmãs e marcadores flanqueando o intervalo indica aproximadamente a fase de ligação nos parentais, permitindo assim determinar a provável origem de um alelo em um marcador não informativo. Pode-se assim determinar a probabilidade de ocorrer um dos alelos do QTL (QQ, Qq, qQ, qq) em cada posição para cada indivíduo. Depois de calcular os coeficientes para um possível QTL a uma dada posição para todos os indivíduos, os efeitos $a$ e $d$ podem ser estimados para aquela posição por quadrados mínimos, fazendo uma regressão dos valores fenotípicos para estes coeficientes.

Knott et al. (1998), sugerem uma seqüência de análises que devem ser realizadas para detecção de QTLs, a qual é apresentada a seguir:

1) A partir dos genótipos dos marcadores dos indivíduos F2 é feita regressão para os coeficientes $a$ e $d$, em intervalos regulares (ex: 1cM). Uma razão simples (estatística F) é calculada para comparar o modelo com 1 QTL com o modelo sem QTL. A localização do QTL é dada pelo local que apresentar maior valor de F, ou seja, a posição em que a soma de quadrados do resíduo é minimizada. Estimativas dos efeitos $a$ e $d$ do possível QTL são obtidas nesta localização. O coeficiente do efeito aditivo mede o afastamento de cada genótipo homozigoto para o QTL em relação à média e o efeito de dominância mede o desvio dos heterozigotos em relação à média.

2) O segundo passo é estudar se há interações com o QTL. É investigada a possibilidade do QTL ter efeitos diferentes para cada sexo, pois se esta diferença existir, os efeitos $a$ e $d$ devem ser estimados para cada sexo separadamente. Testar a interação QTL x família, testa a pressuposição de que alelos alternativos do QTL estão fixados nas linhagens, mas este teste necessita de famílias F2 de tamanho razoável.

3) O terceiro passo é testar se há efeito "imprinting" (efeito gamético), ou seja, se há diferença entre os indivíduos heterozigotos receberem cada alelo através do macho ou da fêmea. Um modelo adicionando "imprinting" aos efeitos $a$ e $d$ de um QTL é comparado com o modelo sem QTL (com 3 graus de liberdade). Se for significativo, este modelo é comparado com o melhor modelo com QTL, sem "imprinting", para verificar se o efeito do "imprinting" é significativo. Esta análise só pode ser realizada em populações não endogâmicas, onde quatro alelos estão segregando tornando possível identificar os dois tipos de heterozigotos. 
4) É realizada uma análise bidimensional fixando coeficientes ( $a$ e $d$ ) para localizar duas posições simultaneamente no mesmo cromossomo. Deve-se fixar um QTL na melhor posição enquanto procura-se o segundo, testando assim um modelo com 2 QTLs. A análise é realizada comparando o modelo com 2 QTLs com o modelo com 1 e sem QTL (com 2 e 4 graus de liberdade, respectivamente). Se o modelo for significativo, considera-se a presença do segundo QTL. Um teste F padrão deve ser usado para testar se os dois QTL no cromossomo explicam significativamente $(\mathrm{P}<$ $0,05)$ mais variância fenotípica que o modelo com um QTL.

O modelo genético descrito anteriormente assume a pressuposição de que alelos alternativos do QTL estão fixados nas linhagens ou raças utilizadas nos cruzamentos para estudos de mapeamento. Se esta pressuposição for violada o poder de detectar QTL é diminuído. Embora Alfonso \& Haley (1998) tenham demonstrado que a análise de F2 ("line-cross") seja robusta o suficiente para suportar algum desvio desta pressuposição, ela é mais poderosa quando os alelos estão fixados nas linhagens e quando o efeito do QTL é de natureza dominante.

Knott et al. (1996) e De Koning et al. (1999) descrevem a utilização do modelo de meio-irmãos (half-sib) como uma opção de análise. Na análise de meio-irmãos não são feitas pressuposições sobre o número de alelos do QTL ou fixação de alelos nas linhagens ou raças parentais. De Koning et al. (2001) demonstraram em seu estudo que a violação da pressuposição de alelos fixados no cruzamento estudado foi tão severa que a análise de meio-irmãos foi superior a análise de F2 para a detectar os QTLS.

A análise de meio-irmãos também pode ser realizada por mapeamento de intervalo utilizando análise de regressão. Para cada posição são calculadas as probabilidades condicionais dos indivíduos F2 herdarem o alelo "Q" do QTL de um macho fornecendo uma variável independente sobre a qual a característica fenotípica pode ser regredida. Em análises simultâneas para vários machos, a regressão deve ser feita dentro de cada macho. Isto porque nem todos os machos serão heterozigotos para o QTL, e também a fase de ligação entre os alelos do QTL e alelos dos marcadores pode variar de macho para macho (Knott et al. 1996). Uma análise (estatística F) é calculada a cada cM através do genoma e a posição com um maior valor de F é considerada a posição mais provável do QTL. Então, para cada família de 
meio-irmãos o efeito de substituição de alelo do QTL é calculado a cada cM ao longo de cada cromossomo.

Segundo De Koning et al. (1999), a combinação de ambas as análises, F2 e meio-irmãos, fornece mais informações sobre o número de QTLs que afetam as características de interesse, seu modo de ação na população estudada, sobre a validade das pressuposições e a natureza dos efeitos (aditivo ou de dominância) dos QTLs detectados.

$\mathrm{Na}$ análise F2 os efeitos aditivo e de dominância de um QTL são calculados para a população como um todo e os QTLs mapeados explicam a variação genética entre as linhagens fundadoras. Na análise de meio-irmãos um único efeito de substituição do alelo é calculado dentro de cada família de meio-irmãos e os QTLs mapeados explicam a variação dentro de família (De Koning et al., 1999).

\subsection{Intervalo de Confiança}

A determinação do intervalo de confiança para um QTL pode ser obtida pelo método de reamostragem "bootstrap" (Visscher et al., 1996), facilmente utilizado em conjunto com mapeamento por intervalo baseado em regressão. Os autores afirmam que quanto maior a evidência de um QTL estar presente em uma determinada região, menor é o intervalo de confiança (IC).

Segundo Visscher et al. (1996), a amplitude do IC depende do tamanho da população e do efeito do QTL. Foram comparadas duas populações com 200 e 500 indivíduos e o IC foi muito menor para a população maior. Já a variação no espaçamento dos marcadores (10 e 20 cM) não resultou em intervalos de confiança muito diferentes.

A metodologia proposta por Visscher et al. (1996), utilizando o método de reamostragem bootstrap, retira amostras de $\mathrm{N}$ observações (indivíduos) com genótipo dos marcadores e fenótipo. Assim, cada bootstrap gera uma nova população (utilizando amostras com reposição), em que é realizada uma análise estatística para identificar QTLs. Alguns dados podem aparecer mais de uma vez enquanto outros podem nunca ser incluídos em alguma das análises. Após "x" "booststraps" e análises de QTL nestas populações amostradas, o IC de 95\% para o QTL é determinado pelo 
ordenamento das "x" estimativas geradas, retirando-se $2,5 \%$ dos valores nos extremos inferior e superior da distribuição.

\subsection{Nível de significância genômico}

O mapeamento de QTLs é um procedimento de testes múltiplos com intuito de verificar qual ou quais marcadores estão ligados a QTLs. O problema neste procedimento refere-se ao nível de significância conjunto destes testes, chamado de nível de significância genômico.

Segundo Lander \& Kruglyak (1995), é importante fazer distinção entre o nível de significância pontual e o genômico. Esses autores recomendam que três níveis de significância deveriam ser considerados. O primeiro deles, a significância para considerar a ligação sugestiva, correspondendo a um falso positivo apenas ocorrendo em todo o genoma. O segundo, a significância a 5\% no genoma, correspondendo à ligação significativa e o terceiro, a significância a 1\% no genoma, caracterizando uma ligação altamente significativa. O nível de significância genômico é obtido utilizando a correção de Bonferroni, que consiste em determinar o valor do nível de significância no cromossomo que proporcionará o nível de significância conjunto desejado.

Segundo Coelho \& Silva (2002), o problema de usar a correção de Bonferroni para a obtenção do nível de significância individual, que proporcionará o nível de significância conjunto, é que essa correção é obtida considerando $t$ testes independentes, o que não ocorre no mapeamento de QTLs, pois os marcadores podem estar localizados em um mesmo cromossomo. Assim, o verdadeiro valor do nível de significância conjunto obtido é um pouco menor que o desejado, o que reduz a probabilidade de aceitar a hipótese $\mathrm{H}_{0}$ (que considera que não existe QTL ligado ao marcador), aumentando o erro tipo I (falso positivo).

Para amenizar este problema Churchil \& Doerge (1994) propuseram utilizar um procedimento de aleatorização ("data shuffling") para obter uma distribuição empírica da estatística do teste. O procedimento baseia-se no fato de que se os dados obtidos indicam a existência de QTL associado aos marcadores essa associação pode ser destruída embaralhando-se os valores fenotípicos, ou seja, redistribuindo aleatoriamente os valores fenotípicos observados entre os indivíduos, porém 
conservando os genótipos dos marcadores. Se não houver QTLs ligados a regiões específicas do genoma, o processo de aleatorização (permutação) não afetará a distribuição da estatística usada no teste.

A permutação, por ser um procedimento empírico baseado nos marcadores e características utilizadas, reflete aspectos particulares do experimento ao qual é aplicado. É difícil determinar um nível de significância apropriado usando distribuições teóricas, porque muitos fatores podem variar de um experimento para outro e influenciar a distribuição da estatística do teste, como o tamanho da amostra, tamanho do genoma do organismo estudado, densidade do mapa, distorção das taxas de segregação, proporção de dados perdidos e número e magnitude dos QTLs que estão segregando (Churchill \& Doerge, 1994).

Para obter o nível de significância genômico, segundo Churchill \& Doerge (1994), são realizadas "N" permutações e para cada permutação a maior razão F é anotada e os "N" valores de F são ordenados. O valor de F que representa 100(1- $\alpha$ ) \% é tido como ponto de corte de significância, ou seja, representa o nível de significância genômico. O " $\alpha$ " é o valor crítico que define no teste o controle de erro tipo I.

O nível de significância genômico é usado para detectar a presença de QTL em algum lugar em todo genoma, controlando a taxa de erro tipo I (falso positivo) (Churchill \& Doerge, 1994). Os autores afirmam que quanto maior o número de permutações mais precisas são as estimativas. Recomendam 1.000 permutações para obter um nível de significância genômico de 5\% e 10.000 para 1\%. Segundo De Konning et al. (1999), considerando-se o nível de significância no genoma facilita a comparação entre diferentes estudos.

O nível de significância para declarar a existência de um QTL também pode ser expresso na forma de valor de LOD, que indica na escala logarítmica a razão entre a probabilidade dos dados observados terem surgido assumindo a presença de um QTL sobre a probabilidade de sua ausência. O LOD utilizado também depende do número de marcadores testados e do tamanho do genoma em cM (Ferreira \& Grattapaglia, 1998). 


\subsection{Mapeamento de QTLs em outras populações}

Vários estudos utilizando marcadores microssatélites com o objetivo de identificar QTLs para características de interesse na avicultura moderna vêm sendo realizados nos últimos anos. Na Tabela 1 estão resumidos QTLs associados a características de desempenho e carcaça e na Tabela 2 QTLs para resistência a doenças.

No cromossomo 1, Van Kaam et al. (1999a) encontraram ligação sugestiva entre o marcador LEI 71 e peso corporal aos 48 dias de idade. Este mesmo marcador foi associado a peso corporal a 13 e 16 semanas por Tatsuda \& Fujinaka (2001). Esses resultados sugerem que nesta região do cromossomo 1 existem genes que influenciam o crescimento.

Van Kaam,, et al. (1998), Sewalem et al. (2002) e Tuiskula-Haavisto et al. (2002) identificaram uma região do cromossomo 4 ligada a peso corporal das aves utilizando diferentes marcadores. Van Kaam et al. (1999) e Tuiskula-Haavisto et al. (2002) identificaram outra região neste cromossomo associada ao consumo de ração. A partir destes resultados obtidos em populações experimentais, De Koning et al. (2003), em um estudo pioneiro, avaliaram estas regiões do cromossomo 4 anteriormente associadas a QTLs em uma população comercial de frangos de corte, sem alterar o esquema de seleção da população e confirmaram QTLs para peso corporal, consumo de ração e peso do músculo da coxa.

Sewalen et al. (2002) e Kerje et al (2003) detectaram QTLs para peso corporal nos cromossomos 1, 4, 7, 8 e 27 aproximadamente nas mesmas regiões, mas segundo Kerje et al. (2003) devido a precisão das posições nos dois estudos não se pode afirmar que sejam os mesmos QTLs.

No cromossomo 5, McElroy et al. (2002) associaram o marcador MCW193 (50 cM) com peso de gordura em frangos de corte. Ikeobi et al. (2002) encontraram QTLs para peso de gordura abdominal e distribuição de gordura (proporção de gordura subcutânea em relação a gordura abdominal) na região em torno de $74 \mathrm{cM}$. Ikeobi et al. (2002) e Jennen et al. (2004) mapearam QTLs para características ligadas a deposição de gordura no cromossomo 15 a 24 cM, mas utilizando diferentes marcadores. Esses resultados sugerem que nestas regiões dos cromossomos 5 e 15 existem genes que influenciam a deposição de gordura em aves. 
Tabela 1. QTLs mapeados e descritos na literatura para características de desempenho e carcaça, indicando o cromossomo onde foram identificados e a porcentagem da variância fenotípica por eles explicada (sempre que disponível)

\begin{tabular}{|c|c|c|c|}
\hline Característica & Cromossomo & \% da variância fenotípica & Autores \\
\hline Consumo de 23 a $48 \mathrm{~d}$ & $1^{*}$ & - & Van Kaam et al. (1999a) \\
\hline Peso corporal a 13 e 16 semanas & $1^{*}, 2^{*}$ & 12,2 a 41,7 & Tatsuda \& Fujinaka (2001) \\
\hline Empenamento & $Z^{*}$ & & Hamoen et al. (2001) \\
\hline Peso de gordura abdominal & $1^{\star}, 3^{\star}, 5^{\star \star}, 7^{\star \star}, 15^{\star}$ e $28^{*}$ & 3,0 a 5,24 & \\
\hline Gordura da pele e subcutânea & $3^{*}, 7^{*}, 13^{*}, 28^{*}$ & 3,41 a 4,18 & \\
\hline $\begin{array}{l}\text { Gordura da pele ajustada para peso da gordura } \\
\text { abdominal }\end{array}$ & $5^{\star}, 7^{* \star}, 15^{\star}$ & 3,64 a 4,40 & lkeobi et al. (2002) \\
\hline Peso vivo as 3,6 e 9 semanas & $\begin{array}{l}1^{a *}, 2^{\star \star}, 3^{*}, 4^{\star \star}, 7^{\star \star}, 8^{*}, 13^{\star \star} \\
27^{\star} \text { e } Z^{\star *}\end{array}$ & 3,2 a 7,6 & Sewalen et al. (2002) \\
\hline Qualidade de albúmen a 40 semanas & $2^{*}$ & 7 & \\
\hline Idade ao primeiro ovo & $Z^{*}$ & 6,8 & \\
\hline Resistência da casca do ovo & $z^{*}$ & 5 & \\
\hline Peso do ovo & $4^{*}$ e $Z^{*}$ & 10 a 16 & Tuiskula-Haavisto et al. (2002) \\
\hline Número de ovos de 18 a 40 semanas & $8^{*}$ e $Z^{*}$ & 5 a 9,8 & \\
\hline Peso corporal a 40 semanas & $4^{*}$ & 25,8 & \\
\hline Consumo & $4^{*}$ & 5 & \\
\hline Peso da metade frontal da carcaça & $3^{\&}$ & - & \\
\hline Peso do filé & $3^{\&}$ & - & McElroy et al. (2002) \\
\hline Peso de carne branca & $3^{\&}$ & - & \\
\hline Peso vivo a 8, 46, 112 e 200 dias de idade & $\begin{array}{l}1^{\star *}, 2^{*}, 3^{\dagger}, 4^{\dagger}, 5^{*}, 7^{*}, 8^{*} \\
11^{\star *}, 12^{\dagger}, 27^{\star *} \text { e } Z^{*}\end{array}$ & 1,7 a 21,6 & Kerje, et al. (2003) \\
\hline Peso do ovo & $1^{\star \star}, 3^{\dagger}, 4^{\dagger}, 14^{\star \star}$ e $23^{\star \star}$ & 3,8 a 24,1 & \\
\hline Peso vivo a 7 e 10 semanas & $2^{\dagger}, 10^{\dagger}, 13^{\star}$ e $14^{\dagger}$ & - & \\
\hline Peso da gordura abdominal & $1^{\dagger}, 4^{\dagger}, 7^{\dagger}, 11^{\dagger}$ e $13^{\dagger}$ & - & Jennen, et al. (2004) \\
\hline Porcentagem da gordura abdominal & $1^{\star}, 2^{\dagger}, 3^{\dagger}, 4^{\dagger}, 15^{\dagger}, 18^{\dagger}, 27^{\dagger}$ & - & \\
\hline
\end{tabular}


Tabela 2. QTLs mapeados e descritos na literatura para características relacionadas à resistência à doenças, indicando o cromossomo onde foram identificados e a porcentagem da variância fenotípica por eles explicada (sempre que disponível).

\begin{tabular}{|c|c|c|c|}
\hline Característica & Cromossomo & \% da variância fenotípica & Autores \\
\hline $\begin{array}{l}\text { Sobrevivência, } n^{\circ} \text { de dias da infecção por vírus de } \\
\text { Marek até a morte } \\
\text { Índice de tumor }\end{array}$ & $2^{a^{\star}}$ & 7 & Vallejo et al. (1998) \\
\hline $\begin{array}{l}\text { Sobrevivência ( } n^{\circ} \text { de dias da infecção por vírus de } \\
\text { Marek até a morte) }\end{array}$ & $2^{*}$ & 6,6 & \\
\hline Presença de lesão no nervo ciático & $7^{*}$ e $8^{*}$ & 4,4 e 3,4 & \\
\hline Presença de lesão no nervo braquio & $4^{*}$ e $7^{*}$ & 3,1 e 3,3 & Yonash et al. (1999) \\
\hline Presença de sintomas & $2^{*}$ e $4^{*}$ & 3,4 e 5,0 & \\
\hline Índice de tumores & $2^{*}$ e $4^{*}$ & 5,8 e 7,3 & \\
\hline Presença de lesão no nervo vago & $4^{*}$ & 4,7 & \\
\hline Resposta imune para vírus de Newcastle & $2^{*}$ e E31 $1^{*}$ & 3,8 e 2,7 & \\
\hline Resposta imune para hemácias de carneiro & $2^{*}$ & 4,4 & Yonashet al. (2001) \\
\hline Resposta imune e resistência a E. coli & $5^{*}$ & 4,4 & \\
\hline Resposta imune a E.coli & $1^{*}, 3^{*}, 7^{*}$ e $8^{*}$ & - & \\
\hline Resposta imune a Salmonella enteritidis & $1^{*}, 7^{*}$ e $8^{*}$ & - & Yunis et al. (2002) \\
\hline Resistência a coccidiose (contagem de oócitos) & $1^{*}$ & - & Zhu et al. (2003) \\
\hline Susceptibilidade a ascite & $2^{\star \star}, 4^{b}$ e $6^{c}$ & - & Rabie et al. (2002) \\
\hline
\end{tabular}

Susceptibilidade a ascite

Na Tabela estão relacionados apenas QTLs significativos

Significativo a $5 \%$ no genoma, ${ }^{\star \star}$ Significativo a $1 \%$ no genoma, ${ }^{\mathrm{b}}$ Significativo a $4 \%$ no genoma, ${ }^{\mathrm{c}}$ Significativo a $2 \%$ no genoma.

a Presença de 2 QTLs para a característica no mesmo cromossomo. 
Zhu et al. (2003) encontraram uma região próxima ao marcador LEI 101 no cromossomo 1 associada a produção de oócitos, característica relacionada à resistência à coccidiose. Esta região foi anteriormente identificada por Yonash et al. (1999) como afetando viremia em aves infectadas com o vírus da doença de Marek (a um nível sugestivo), com o mesmo marcador. Esses resultados indicam que nessa região existem genes que regulam a resistência a algumas doenças em aves.

Uma região foi associada a resposta imune a Salmonella enteritidis no cromossomo 5, por Kaiser et al. (2002), ligada ao marcador ADL 298, o qual foi anteriormente associado com resposta imune e sobrevivência a E. coli por Yonash et al. (2001). Este marcador está próximo ao loco do gene SAL1, associado a resistência a Salmonella typhimurium por Mariani et al. (2001), sugerindo mais uma região contendo genes responsáveis por resistência a doenças.

A associação de marcadores com QTLs não representa um resultado final da pesquisa. Esta informação precisa ser refinada, validada em outras populações independentes e deve resultar na identificação do gene ou grupo de genes que controlam pelo menos parte da variação fenotípica da característica de interesse. $\mathrm{Na}$ avicultura, esta estratégia ainda não resultou em um marcador que já esteja sendo utilizado no melhoramento, porém, em outras espécies, principalmente em suínos, a utilização de marcadores já é uma rotina em programas de melhoramento. Mas, segundo Burt (2002), vários QTLs estão sob investigação por empresas de genética avícola.

Depois de identificados os QTLs, o próximo passo é a busca por genes nestas regiões, que possam realmente explicar a variação fenotípica de determinada característica. Entendendo como eles funcionam e como influenciam as características de interesse econômico, será possível buscar novos direcionamentos para melhorar o desempenho e a qualidade do produto final. A comparação com mapas genômicos de outras espécies tem auxiliado na procura por genes importantes e potencialmente úteis em aves. Com os avanços na genômica funcional, será possível a descoberta de novos genes, a partir de estudos de expressão gênica, facilitando a dissecação de características poligênicas e a utilização destas informações no melhoramento através da seleção assistida por marcadores (Ledur et al., 2003). 
Grandes avanços são esperados nos próximos anos a partir da primeira versão do seqüenciamento do genoma da galinha que foi divulgada em $1^{\circ}$ de março de 2004 pela Washington University Genome Sequencing Center e o National Human Genome Research Institute nos Estados Unidos. Correções nesta versão serão incorporadas na seqüência do genoma na medida em que mais informações forem geradas. Esses dados serão bastante úteis em futuros estudos de QTL e possivelmente na compreensão da base genética da domesticação e seleção da galinha moderna. Esses esforços irão prover o geneticista de uma lista quase completa de todas as seqüências codificadoras, suas localizações cromossômicas, inúmeros marcadores genéticos e a possibilidade de gerar arranjos de genes para análises de expressão altamente informativas (Andersson e Georges, 2004).

\subsection{Seleção Assistida por Marcadores (MAS)}

Segundo Ferreira \& Grattapaglia (1998), os seguintes aspectos da MAS devem ainda ser investigados antes da sua utilização: 1) A estabilidade da expressão do QTL em diferentes "backgrounds" genéticos e ambientais. 2) O efeito final do acúmulo de alelos supostamente favoráveis em diferentes QTLs no fenótipo. 3) Metodologias de integração prática da informação molecular em índices de seleção. 4) Estimativas comparativas de ganhos genéticos obtidos através da seleção com e sem marcadores. Mas os autores afirmam que a sua utilização vai depender essencialmente de uma análise custo benefício.

Segundo Dekkers \& Hospital (2002), o mérito da MAS não pode ser questionado em situações em que o custo da avaliação molecular compensa a economia feita na avaliação fenotípica, como na seleção para resistência a doenças, qualidade da carne, e também no caso de seleção precoce. Entretanto, o mérito da sua utilização é difícil de ser avaliado quando se espera obter maiores ganhos genéticos através da MAS, quando ela gera aumento de custo, como na seleção combinada, que além do custo molecular, inclui também o fenotípico. Nesse caso, a MAS pode ser menos vantajosa economicamente que a seleção tradicional. Os autores comentam sobre a necessidade urgente de pesquisas sobre avaliação econômica de estratégias de seleção que utilizam métodos de genética molecular e 
que, por enquanto, a avaliação fenotípica ainda é um componente muito importante em programas de seleção, pois leva em consideração o efeito coletivo dos genes.

Burt (2002) sugere alguns pontos que ainda causam algum receio na transferência de tecnologia genômica para a indústria avícola. Dentre os obstáculos estão os altos custos da descoberta de genes e sua exploração em termos de infraestrutura, recursos, tecnologia e habilidades e a aceitação do público. Entretanto, o autor salienta que a descoberta de QTLs e genes é apenas uma fase de pesquisa, o que é passível de ser realizado em algumas universidades e instituições de pesquisa com o apoio das empresas privadas. Quanto ao aceite público, Burt (2002) comenta que "é nossa a responsabilidade de explicar ao público que a genômica em aves é uma ciência que não cria variação genética, mas é apenas uma ferramenta precisa que detecta a variação natural em populações melhoradas". 


\section{MATERIAL E MÉTODOS}

\subsection{População experimental}

A população referência utilizada no presente estudo foi desenvolvida na Embrapa Suínos e Aves, em Concórdia, SC. Foram utilizadas duas linhagens de aves divergentes, uma de corte (TT) e outra de postura (CC). Essas linhagens apresentam composições genéticas distintas, pois a linhagem para corte teve sua origem a partir do cruzamento das raças Cornish, Hampshire e White Plymouth Rock, enquanto a linhagem de postura foi originada da raça White Leghorn. Essas linhagens foram selecionadas por várias gerações para características distintas, sendo que a maioria delas apresenta correlações negativas, como por exemplo, peso e produção de ovos.

A linhagem TT é uma linha macho, cuja seleção foi efetuada dentro de linha desde 1985, com o objetivo de melhorar o peso corporal, conversão alimentar, rendimento de carcaça e partes, viabilidade, fertilidade e eclodibilidade; e reduzir a gordura abdominal e doenças metabólicas. Na época em que a população referência foi formada a linhagem TT havia sido selecionada para estas características por seis gerações. A linhagem CC foi selecionada por oito gerações desde 1989, para melhorar a produção de ovos, peso do ovo, conversão alimentar, viabilidade, maturidade sexual, fertilidade, eclodibilidade, qualidade do ovo e reduzir o peso corporal.

Na formação da população referência para o estudo de mapeamento de QTLs foram realizados cruzamentos recíprocos das duas linhagens, na proporção de um macho para cada fêmea. Foram utilizados 7 machos e 7 fêmeas de cada linhagem em cada cruzamento recíproco. As aves foram mantidas em gaiolas individuais com controle de pedigree e os ovos foram identificados para possibilitar o anelamento ao nascer dos pintos da primeira geração, chamados de F1. A geração F1 consta de 7 famílias obtidas do cruzamento de machos de corte com fêmeas de postura (TC) e 7 
famílias do cruzamento de machos de postura com fêmeas de corte (CT). Em cada família foram escolhidos ao acaso 3 machos e 6 fêmeas F1. Estas aves foram criadas como matrizes de frango de corte e alojadas em gaiolas individuais. Na Tabela 3 são apresentadas algumas características de peso e carcaça para caracterização das linhagens e cruzamentos.

Tabela 3. Médias estimadas de peso corporal aos 41 dias de idade (P41) e rendimentos de carcaça (RC), peito (RP) e gordura (GOR). Fonte: Ledur et al. (2000)

\begin{tabular}{ccccc}
\hline Grupo Genético & $\mathrm{P} 41(\mathrm{~g})$ & $\mathrm{RC}(\%)$ & $\mathrm{RP}(\%)$ & $\mathrm{GOR}(\%)$ \\
\hline CC & $513,7 \mathrm{a}$ & $64,2 \mathrm{a}$ & $14,2 \mathrm{a}$ & $0,16 \mathrm{a}$ \\
TT & $2395,4 \mathrm{~b}$ & $74,6 \mathrm{~b}$ & $20,4 \mathrm{~b}$ & $2,41 \mathrm{~b}$ \\
$\mathrm{CT}$ & $1573,4 \mathrm{c}$ & $70,9 \mathrm{C}$ & $18,3 \mathrm{C}$ & $1,92 \mathrm{c}$ \\
TC & $1193,3 \mathrm{~d}$ & $70,0 \mathrm{c}$ & $17,3 \mathrm{~d}$ & $1,51 \mathrm{~d}$ \\
Média & 1472,6 & 70,0 & 17,4 & 1,65 \\
\hline
\end{tabular}

Para a formação da segunda geração, chamada de F2, foram selecionados 1 macho e 3 fêmeas ao acaso de diferentes famílias da população F1. Cada macho F1 fecundou 3 fêmeas $F 1$, através de inseminação artificial, evitando-se parentes próximos. Um total de 7 machos e 21 fêmeas F1 de cada cruzamento (TC e CT) geraram cerca de 100 pintos F2 por família de F1 em 17 incubações, com intervalos de 15 dias durante quase 8 meses, totalizando cerca de 4000 aves F2 (metade de cada sexo e de cada cruzamento CT e TC).

Essa população F2 foi anelada, com controle de pedigree individual, e avaliada para várias características de desempenho e carcaça. As aves foram criadas como frangos de corte recebendo ração e água à vontade. Os animais receberam ração inicial de 1 a 21 dias de idade (com 21\% de proteína bruta - P.B., e $3.150 \mathrm{kcal}$ de energia metabolizavel - E.M.), de 22 a 35 dias de idade receberam ração de crescimento (com $20 \%$ de P.B. e 3.200 kcal de E.M.) e ração final de 36 a 41 dias (com $18,5 \%$ de P.B. e $3.200 \mathrm{kcal}$ de EM). As rações foram à base de milho e farelo de soja, formuladas para atender as necessidades nutricionais das aves.

As aves foram mantidas em boxes coletivos até 35 dias de idade, quando cada ave foi pesada e alojada em gaiola individual para teste de conversão alimentar dos 35 aos 41 dias. 
Neste estudo optou-se pela genotipagem das famílias TC devido ao tempo e aos custos para realização do projeto. Nas Tabelas 4 e 5 são apresentadas a estrutura da população referência e as relações de parentesco, respectivamente.

Tabela 4. Estrutura populacional do cruzamento TC, número de aves empregadas nas análises e o tipo de dados coletados

\begin{tabular}{ccccc}
\hline Geração & Machos & Fêmeas & Total & Dados coletados \\
Parental & 7 & 7 & 14 & genótipos \\
F1 & 7 & $20^{\mathrm{a}}$ & 27 & genótipos \\
F2 & 1039 & 1024 & 2063 & fenótipos \\
& 84 & 86 & 170 & genotigem seletiva \\
& 328 & 325 & 653 & genótipos $^{1}$
\end{tabular}

${ }^{\mathrm{a}}$ Houve perda por morte de uma fêmea F1.

${ }^{1}$ Número total de animais F2 genotipados de 7 famílias, selecionadas para o maior número de marcadores informativos daqueles associados a QTL na genotipagem seletiva.

Tabela 5. Relações de parentesco nas famílias originadas do cruzamento TC

\begin{tabular}{|c|c|c|c|c|c|c|c|}
\hline macho TT & 5649 & $\underline{5661}$ & 5561 & 6232 & $\underline{5921}$ & 6037 & $\underline{5596}$ \\
\hline fêmea CC & 886 & 88 & 570 & 332 & 37 & 241 & 05 \\
\hline (no casal) & (1) & (2) & (3) & (4) & (5) & (6) & (7) \\
\hline
\end{tabular}

$\begin{array}{crrrrrrr}\text { Casais F1: } & & & & & & \\ \text { machoTC } & \frac{7716(1)}{7761(7)} & \frac{7769(2)}{7749(6)} & \frac{7797(3)}{7972(5)} & \frac{7822(4)}{7765(2)} & \frac{7975(5)}{7713(3)} & \frac{7977(6)}{7722(1)} & \frac{7985(7)}{7805(1)} \\ \text { fêmeasTC } & 7810(4) & 7816(4) & 7812(4) & 7971(5) & 7980(7) & 7771(2) & 7736(4) \\ \text { (no casal } & 7978(6) & 7709(3) & 7992(2) & 7798(3) & 7755(6) & 7987(7) & 7743(5) \\ \text { parental) } & & & & & & & \\ & & & & & & & \\ & & & & & & & \\ \text { № de F2 } & 100(7761) & 96(7749) & 99(7972) & 73(7765) & 95(7713) & 102(7722) & 88(7805) \\ \text { gerados por } & 77(7810) & 97(7816) & 100(7812) & 100(7971) & 104(7980) & 100(7771) & 103 \\ \text { mãe } & 100(7978) & 100(7709) & 108(7992) & 97(7798) & 101(7755) & 80(7987) & (7736) \\ \text { (№ da mãe F1) } & & & & & & & (7743) \\ \end{array}$

Os números apresentados para machos e fêmeas são equivalentes aos anéis das aves. 


\subsection{Coleta dos dados fenotípicos e de sangue}

As características fenotípicas para avaliar o desempenho foram: peso ao nascer (PN), peso aos 35 (P35), 41 (P41) e 42 (P42) dias de idade. O P42 foi medido após 6 horas de jejum e transporte para o abate. Foram avaliados também, ganho de peso (GP), consumo de ração (CR) e conversão alimentar (CA) dos 35 aos 41 dias de idade. Após o abate as aves foram submersas em água quente para facilitar a depena. As carcaças foram evisceradas e o peso de pulmão (Pul), fígado (Fig), coração (Cor), moela (Mo) e comprimento do intestino (Cl) foram avaliados. As características de carcaça foram avaliadas após resfriamento de 4 horas. Foram avaliados o peso da carcaça ( $C$ - peso da carcaça sem vísceras, pés e cabeça) e peso de partes, peito (PPet), coxas (PC- pesos de coxas e sobre-coxas), carcaça residual ( $R$ - peso da carcaça menos peso de peito, asas e coxas), asas (PA), gordura abdominal (GA) e pés (PP). Todos dados fenotípicos obtidos estão armazenados em um banco de dados do setor de melhoramento de aves da EMBRAPA, para realização de diversos estudos de genes candidatos e mapeamento de QTLs.

Amostras de sangue foram coletadas em tubos contendo EDTA 10\% e armazenados em "freezer" a $-70^{\circ} \mathrm{C}$ para posterior extração de DNA. Foram coletados $5 \mathrm{~mL}$ de sangue (da veia braquial, em 3 vezes, aproximadamente 1,6 mL/semana) dos parentais. O sangue dos animais F1 e F2 foi coletado no abate após o corte na jugular. A conclusão dos abates ocorreu em agosto de 2000 e a organização e separação de alíquotas do sangue coletado foram feitas até março de 2001. As alíquotas foram trazidas para a ESALQ/USP, em Piracicaba e o restante foi mantido como um banco de sangue na Embrapa Suínos e Aves para futuros estudos.

\subsection{Extração de DNA}

Foram testadas várias metodologias de extração de DNA, com o objetivo de determinar a mais rápida, de fácil execução e que permitisse a obtenção de DNA íntegro e em quantidade suficiente para as análises. Foram testados alguns protocolos de extração de DNA, como o método de Hillel et al. (1989) e Hillel modificado (Anexos 1 e 2, respectivamente). Testou-se também o reagente DNAzol ${ }^{\circledR}$ (Invitrogem Life 
Technologies), seguindo o protocolo recomendado pelo fabricante (Anexo 3). Uma alteração foi feita neste protocolo de extração (Anexo 4) para testes e para a escolha do melhor método de extração.

Para amostras cuja ressuspensão do DNA não foi completa ou não foi possível a extração pelos métodos descritos acima, foi feita a extração utilizando proteinase $\mathrm{K}$ (Anexo 5).

Todas as amostras de DNA tiveram a concentração determinada no espectrofotômetro (HITACHI, modelo U-2000) e posteriormente a concentração foi padronizada para 20ng/ $\mu \mathrm{L}$. Após a padronização da concentração, todas as amostras foram testadas em agarose (1\%) para certificação da qualidade do DNA, quanto à quantidade e integridade.

\subsection{Escolha dos marcadores microssatélites}

Os iniciadores (primers) testados e utilizados no presente estudo fazem parte dos "kits" 3, 4 e 7 de uma série de "kits", contendo diversos iniciadores, distribuídos gratuitamente pela Michigan State University através do projeto "Chicken Genome Project". Os "kits" utilizados contém respectivamente 33, 10 e 21 iniciadores localizados no cromossomo 1, que estão listados na Tabela 6, juntamente com a sua posição em centiMorgans (cM). As posições apresentadas foram determinadas no mapa consenso 2000 (CN) ou nos mapas de ligação das populações Compton (C), East Lansing (E) e Wageningen (W).

Após a genotipagem seletiva foram testados mais 14 iniciadores doados pelo Instituto Roslin (Tabela 6), na tentativa de reduzir o espaçamento entre marcadores nas regiões associadas a QTLs. Foram também sintetizados 7 pares de iniciadores (MCW 10, MCW68, ROS25, MCW18, ADL319, MCW58, MCW20) que haviam sido associados a QTLs em estudos anteriores, para serem testados na presente população.

Todos os detalhes sobre os marcadores utilizados (Tabela 6), como seqüência dos iniciadores, tamanho do produto amplificado, temperatura de anelamento e condições de amplificação, podem ser obtidos na página do Chicken Genome Project: http://www.genome.iastate.edu/chickmap/. 
Tabela 6. Marcadores doados pela Michigan State University e Instituto Roslin, com as respectivas posições no cromossomo (cM), de acordo com o mapa consenso (CN) ou mapa de ligação de Wageningen (W), East Lasnsing (E) ou Compton (C)

\begin{tabular}{|c|c|c|c|c|c|c|c|}
\hline \multicolumn{2}{|c|}{ Kit 3} & \multicolumn{2}{|c|}{ Kit 4} & \multicolumn{2}{|c|}{ Kit 7} & \multicolumn{2}{|c|}{ Roslin } \\
\hline Marcador & Posição & Marcador & Posição & Marcador & Posição & Marcador & Posição \\
\hline MCW 208 & $39(W)$ & LEI 209 & $52(E)$ & MCW 168 & $24(\mathrm{CN})$ & ADL 160 & $33(\mathrm{CN})$ \\
\hline MCW 11 & $64(W)$ & LEI 194 & $81(\mathrm{CN})$ & MCW 106 & $53(\mathrm{C})$ & & \\
\hline MCW 254 & $85(\mathrm{CN})$ & LEI 252 & $109(E)$ & HUJ 01 & $54(\mathrm{CN})$ & LEI 68 & $120(W)$ \\
\hline LEI 68 & $120(W)$ & LEI 193 & $113(E)$ & GCT06 & $66(\mathrm{CN})$ & ADL 307 & $128(\mathrm{CN})$ \\
\hline MCW 289 & $120(W)$ & & & ADL 19 & $122(\mathrm{CN})$ & ADL 188 & $133(\mathrm{CN})$ \\
\hline MCW 297 & $162(\mathrm{CN})$ & & & ADL 234 & $151(\mathrm{CN})$ & & \\
\hline LEI 146 & $169(\mathrm{CN})$ & & & & & & \\
\hline MCW 19 & $170(W)$ & & & ADL 150 & $190(E)$ & MCW 112 & $205(\mathrm{CN})$ \\
\hline LEI174 & $176(W)$ & & & & & ADL 252 & $211(E)$ \\
\hline LEI 71 & $211(W)$ & & & & & & \\
\hline LEI 138 & $221(E)$ & & & MCW 101 & $248(\mathrm{CN})$ & & \\
\hline LEI 101 & $259(\mathrm{CN})$ & & & ADL 251 & $267(\mathrm{CN})$ & & \\
\hline LEI 137 & $265(W)$ & & & ADL 20 & $274(E)$ & ADL 20 & $274(E)$ \\
\hline MCW 313 & $271(W)$ & LEI 217 & $286(E)$ & LEI 217 & $286(E)$ & ADL 314 & $281(\mathrm{CN})$ \\
\hline MCW 218 & $271(W)$ & & & & & & \\
\hline LEI 108 & $300(\mathrm{CN})$ & & & & & & \\
\hline MCW 195 & $302(\mathrm{CN})$ & & & & & & \\
\hline LEI 128 & $305(\mathrm{CN})$ & & & ADL 037 & $319(E)$ & & \\
\hline LEI 160 & $309(\mathrm{CN})$ & LEI 198 & $325(E)$ & UMA 1.117 & $325(\mathrm{CN})$ & ADL 148 & $319(E)$ \\
\hline LEI 88 & $316(\mathrm{CN})$ & & & & & ADL 037 & $319(E)$ \\
\hline MCW 200 & $330(\mathrm{CN})$ & GCT 05 & $359(E)$ & & & GCT 05 & $359(E)$ \\
\hline LEI 139 & $356(W)$ & & & & & MCW 036 & $386(\mathrm{CN})$ \\
\hline LEI 91 & $366(\mathrm{CN})$ & & & & & & \\
\hline LEI 106 & $382(E)$ & LEI 246 & $407(E)$ & LEI 169 & $400(\mathrm{CN})$ & & \\
\hline LEI 169 & $400(\mathrm{CN})$ & & & MCW 023 & $411(W)$ & & \\
\hline LEI 79 & $413(W)$ & & & & & & \\
\hline MCW 283 & $414(\mathrm{CN})$ & & & LAMP 1 & $418(\mathrm{CN})$ & & \\
\hline MCW 177 & $416(W)$ & & & & & ROS 076 & $420(W)$ \\
\hline MCW255 & $421(W)$ & & & & & & \\
\hline LEI 107 & $424(\mathrm{CN})$ & & & & & & \\
\hline LEI 168 & $428(W)$ & ADL 328 & $448(W)$ & MCW 145 & $455(\mathrm{CN})$ & ADL 198 & $435(E)$ \\
\hline LEI 84 & $431(E)$ & GCT 01 & $496(E)$ & ADL 101 & $500(\mathrm{CN})$ & ADL 183 & $443(\mathrm{CN})$ \\
\hline \multirow[t]{3}{*}{ LEI 134} & $527(W)$ & & & ADL 238 & $497(W)$ & & \\
\hline & & & & ABR 328 & $536(\mathrm{CN})$ & & \\
\hline & & & & MCW 107 & $565(\mathrm{CN})$ & & \\
\hline
\end{tabular}

?? Marcadores que não se encontram descritos no site: www.genome.iastate.edu. 


\subsection{Amplificação por PCR}

Os iniciadores liofilizados foram solubilizados com T.E. (Tris - EDTA) para obter-se uma concentração de 25 pmoles/ $\mu \mathrm{L}$. Para utilização na reação de PCR a solução estoque foi dividida em alíquotas que foram diluídas com água mili-Q, para uma concentração de 2,5 pmoles/ $\mu \mathrm{L}$, concentração utilizada na reação. Nas Tabelas 7 e 8 são apresentados os programas e condições de PCR para amplificação dos iniciadores. Entretanto, as temperaturas de anelamento (passo 3 - Tabela 7), de 46 a $63^{\circ} \mathrm{C}$, e as concentrações de magnésio $\left(\mathrm{MgCl}_{2}-\right.$ Tabela 8$)$, de 50 a $100 \mathrm{mM}$, variaram de acordo com o iniciador em teste, seguindo a recomendação do site: http://www.genome.iastate.edu/chickmap/.

Tabela 7. Programa utilizado nos termocicladores para amplificação dos marcadores Condições utilizadas para marcadores MCW, LEI, ADL e ROS

\begin{tabular}{lc}
\hline 1 & $95^{\circ} \mathrm{C}$ por 2 minutos \\
2 & $94^{\circ} \mathrm{C}$ por 1 minuto \\
3 & 46 a $63^{\circ} \mathrm{C}$ por 1 minuto* \\
4 & $72^{\circ} \mathrm{C}$ por 1 minuto \\
5 & Repetir passos 2 ao 4 (34 vezes) \\
6 & $72^{\circ} \mathrm{C}$ por 10 minutos \\
7 & $4^{\circ} \mathrm{C}$ indefinidamente \\
8 & fim \\
\hline
\end{tabular}

* Dependendo do marcador

$\mathrm{Na}$ fase de otimização das condições de PCR o material foi amplificado em tubos eppendof de $200 \mu \mathrm{L}$ e testado em agarose $(2,0 \%)$ sob eletroforese. Foram aplicados $10 \mu \mathrm{L}$ do produto amplificado e $2 \mu \mathrm{L}$ de azul de bromofenol por canaleta e 4 $\mu \mathrm{L}$ do marcador de peso molecular $\phi \times 174$ (Promega) na primeira canaleta para verificação do tamanho do fragmento, intensidade das bandas e o aparecimento de bandas inespecíficas. 
Tabela 8. Condições de amplificação dos primers

\begin{tabular}{|c|c|}
\hline & LEI,MCW, ADL, ROS,GCT $(\mu \mathrm{L})$ \\
\hline Água milli-Q & 7,3 \\
\hline Tampão (10x) & 2,5 \\
\hline $\mathrm{MgCl}_{2}(25 \mathrm{mM})$ & $2,0$ a 4,0 (50 a $100 \mathrm{mM})^{*}$ \\
\hline dNTP (10mM) & 1,0 \\
\hline Primer R (2,5pmoles/ $\mu \mathrm{L})$ & 2,5 \\
\hline Primer F (2,5pmoles/ $\mu \mathrm{L})$ & 2,5 \\
\hline Taq DNA pol $(5 \mathrm{U} / \mu \mathrm{L})$ & 0,2 \\
\hline DNA (20 ng/ $\mu \mathrm{L})$ & 5,0 \\
\hline Volume Total & 25,0 \\
\hline
\end{tabular}

Em todas as fases do estudo, amostras das amplificações foram testadas em agarose (2,0\%) antes de serem genotipadas no seqüenciador, tentando com isso evitar falhas na genotipagem.

\subsection{Seleção de marcadores informativos}

Após a otimização das condições de PCR os marcadores selecionados foram genotipados nos animais F1 TC (7 machos e 20 fêmeas) para escolha de marcadores informativos que seriam posteriormente utilizados na genotipagem dos animais F2. Seguindo a classificação sugerida por Zhu et al. (2001), os marcadores foram considerados informativos quando pelo menos um F1 foi heterozigoto e o outro pai teve um genótipo diferente para o locus.

A genotipagem nesta fase foi feita no seqüenciador automático $A B I 377$ (Applied Biossystems). Utilizou-se um conjunto de 3 marcadores por canaleta, agrupados conforme o tamanho e a marcação (fluorescência) do iniciador. As corridas foram feitas em gel de poliacrilamida desnaturante a 6\% com padrão TAMRA 500 (Applied Biossystems). O tamanho dos fragmentos (alelos) foram determinados pelo programa GENOTYPER (Applied Biossystems). Os marcadores foram selecionados de acordo com o número de famílias (casais F1) em que eram informativos e por sua posição no cromossomo. 


\subsection{Genotipagem Seletiva}

\subsubsection{Seleção dos animais}

Para aplicar a estratégia da genotipagem seletiva foi realizada a revisão de todos os dados fenotípicos, com o objetivo de descartar dados discrepantes ("outliers") e corrigir possíveis erros de digitação e descartar da análise todos os dados que apresentassem problemas. Também foram descartados animais cujas amostras de sangue não estavam disponíveis.

Os animais foram separados em dois grupos, de acordo com o sexo, e cada grupo foi ajustado para o efeito de incubação. A separação em dois grupos e o ajuste foram feitos para eliminar os efeitos de sexo e ambientais, respectivamente. A escolha da característica a ser utilizada na genotipagem seletiva recaiu sobre aquela que apresentou correlação fenotípica mais elevada com um maior número de características a serem empregadas no mapeamento de QTLs.

A seleção dos animais foi realizada dentro de família para evitar que alguma família não fosse representada e com isso diminuísse o poder de detecção de QTLs. Neste estudo, a proporção de animais selecionados nos extremos de cada família foi de $4,5 \%$ dos animais mais leves e $4,5 \%$ dos mais pesados, totalizando 170 animais F2 (9\% da população TC), variando de 6 a 10 animais por família, com 84 machos e 86 fêmeas. A porcentagem de indivíduos selecionados atendeu à conveniência da montagem de 2 placas para a posterior genotipagem.

\subsubsection{Genotipagem}

Os animais selecionados foram genotipados para marcadores selecionados de acordo com o número de famílias em que eles foram informativos e a sua posição no cromossomo 1. A genotipagem foi realizada no seqüenciador MEGA Bace (Amersham Bioscience), em placas de 96 poços, organizadas de forma a manter o DNA dos animais F2 de cada uma das famílias F1 em uma mesma placa com os respectivos parentais. Os 14 parentais foram utilizados como controle interno das placas, sendo organizados de forma que 10 e 12 parentais estivessem em cada uma delas. Alguns parentais se repetiram nas placas; eles foram utilizados como controle para 
confirmação dos genótipos e para evitar confundimento dos genótipos que pudessem ser causados pela migração diferenciada dos fragmentos entre os diferentes capilares do seqüenciador e entre placas. Esses animais também foram utilizados para escolher as famílias mais informativas com relação aos marcadores associados a QTLs pelo teste de Qui-quadrado, realizado com os dados da genotipagem seletiva.

Apesar da amplificação de cada marcador avaliado ser individual, as genotipagens foram feitas a partir da mistura do produto amplificado de 3 a 4 marcadores, de acordo com tamanho do fragmento e fluorescência do iniciador, juntamente com o padrão interno (ET-ROX 400 - Amersham Bioscience) utilizado para cálculo do tamanho dos fragmentos. O programa utilizado para representação gráfica dos picos de fluorescência e determinação do tamanho dos fragmentos foi o GENETIC PROFILER (Amersham Bioscience). Todos os picos e tamanhos foram conferidos manualmente. Indivíduos F2 que apresentaram erros na segregação dos alelos em mais de 2 marcadores (ex: apresentaram alelos que não estavam presentes na família) foram removidos da análise.

\subsubsection{Teste de Qui-quadrado}

Utilizou-se o teste de Qui-quadrado como análise preliminar de ligação entre o marcador e o QTL na genotipagem seletiva. Após a genotipagem dos animais F2, estes foram separados em 2 grupos de 85 animais, leves e pesados, para a realização do teste de qui-quadrado $\left(\chi^{2}\right)$, utilizando-se a seguinte equação:

$$
\chi^{2}=\sum_{i=1}^{k} \frac{\left(f o_{i}-f e_{i}\right)^{2}}{f e_{i}}
$$

Onde, $f o_{i}$ e $f e_{i}$ são as freqüências alélicas observada e esperada do grupo $i$, de um total de $k$ grupos.

A hipótese $H_{0}$ testada é de que a freqüência alélica do marcador é igual nos grupos de animais leves e pesados, ou seja, que o marcador não está ligado a um QTL. O procedimento utilizado para a análise foi o PROC FREQ do pacote estatístico SAS (2001). Os marcadores associados $(P<0,10)$ a QTLs nesta análise preliminar foram selecionados para genotipar todos os indivíduos F2 de sete famílias F1 para o mapeamento de QTLS. 


\subsection{Genotipagem completa}

Foram selecionadas para serem genotipadas 7 famílias F1 completas, totalizando 653 animais F2. A escolha das famílias foi feita a partir dos marcadores associados a QTLs na genotipagem seletiva, ou seja, foram escolhidas as famílias em que um maior número destes marcadores foram informativos. Estas famílias foram também genotipadas para outros marcadores posicionados próximos às regiões identificadas na genotipagem seletiva como possivelmente contendo QTLs, visando reduzir o espaçamento entre marcadores para um mapeamento mais fino.

\subsection{Mapa de Ligação}

Os genótipos obtidos foram submetidos ao programa CRI-MAP (Green et al., 1990) para a determinação das distâncias entre os marcadores, ou seja, para a construção do mapa de ligação da população.

O procedimento empregado no programa CRI-MAP foi: (1) TWOPOINT, que determina possível ligação para cada par de marcadores, gerando valores de LOD como probabilidade de ocorrência da ligação. (2) BUILD, opção que determina ligação entre os marcadores e os ordena de acordo com a taxa de recombinação que ocorre entre eles. (3) FLIPS, confere os valores de LOD enquanto vai alterando a ordem de cada marcador, enquanto os outros permanecem fixos. Para comprovação de ligação foi aceito um valor de LOD superior a 2, que sugere que a hipótese dos marcadores estarem ligados é 100 vezes mais verossímel (provável) que a hipótese de não estarem ligados. (4) CHROMPIC, mostra a fase de ligação dos marcadores alinhados no cromossomo, para cada indivíduo. Esta opção foi executada para identificar animais que apresentaram duplas ou triplas recombinações e estes tiveram as leituras dos genótipos reexaminadas nos respectivos eletroferogramas.

\subsection{Análise de QTLs}

Para as análises de mapeamento de QTLs, foram realizadas análises exploratórias dos dados fenotípicos no SAS (2001). O objetivo destas análises foi identificar dentre efeitos fixos (família, sexo, incubação e suas interações) e covariáveis 
(P35 e P42), quais eram significativos sobre o fenótipo, permitindo assim determinar o modelo para o mapeamento de QTLs, para cada uma das seguintes características: PN, P35, P41, P42, GP, CR, CA, C, PPet, PC, PA, R, GA, PP, Cl, Mo, Fig, Pul e Cor.

Primeiramente foi realizada uma análise exploratória para cada característica para identificar possíveis valores discrepantes. Após estas análises optou-se por eliminar, para cada variável dentro de família, sexo e incubação, as observações que se encontrassem fora do intervalo da média \pm 4 desvios-padrão, assumindo-se que tais observações eram valores discrepantes. Optou-se por utilizar \pm 4 desvios-padrão pela grande variabilidade dos dados em estudo, o que é esperado na segunda geração de cruzamentos de linhagens divergentes.

Optou-se então por ajustar as características para o efeito de incubação e utilizar os resíduos da análise para o mapeamento de QTLs, ao invés de incluir este fator no modelo. Esta decisão foi tomada porque nas incubações há efeitos de outros fatores que não são possíveis de separar tais como efeito ambiental, uma vez que as incubações começaram em janeiro e se estenderam até julho e o efeito da idade da mãe, que também variou nesse período.

Após o ajuste para o efeito de incubação, testaram-se os resíduos para os efeitos fixos de sexo, família, interação entre sexo e família e as covariáveis P35 e P42, levando em consideração as particularidades de cada característica. Para as características de desempenho foi utilizado, como covariável, o P35 e para as características de carcaça foi utilizado o P42.

Houve efeito significativo $(P<0,10)$ da interação sexo $x$ família para as características: peso de pés, asas, peito e pulmão. Os dados fenotípicos dessas características foram ajustados para o efeito da interação (sexo x família). Os resíduos do ajuste de incubação e interação sexo x família foram utilizados no mapeamento de QTLs, dado que o QTL EXPRESS (Seaton et al., 2002) (http://qtl.cap.ed.ac.uk), programa que foi usado no mapeamento de QTL, não permite o ajuste para efeitos de interação.

Os genótipos, fenótipos (resíduos) e o mapa contendo as distâncias entre marcadores foram submetidos ao programa QTL EXPRESS, onde foram realizadas as análises estatísticas utilizando mapeamento de intervalos, empregando regressão linear e método dos quadrados-mínimos. 
Dois modelos genéticos foram utilizados para a análise dos dados: 1) análise de F2 (line-cross) conforme Haley et al. (1994), que assume que as linhagens fundadoras estão fixadas para diferentes alelos do QTL e 2) análise de meio-irmãos paternos (paternal half-sib) conforme Knott et al. (1996), que não faz pressuposições quanto ao número e alelos do QTL nem de fixação de alelos.

\subsubsection{Análise de F2}

Este modelo assume que as duas linhagens TT e CC estão fixadas para diferentes alelos do QTL que está afetando a característica de interesse, mesmo que elas estejam compartilhando alelos do marcador. A probabilidade de cada indivíduo F2 pertencer a cada um dos quatro genótipos do QTL (QQ, Qq, qQ e qq) foi calculada a partir dos genótipos dos marcadores flanqueadores, em cada posição do genoma, em intervalos de $1 \mathrm{cM}$.

Um modelo linear contendo os efeitos aditivos e de dominância de um QTL em uma dada posição foi ajustado e o método dos quadrados-mínimos foi usado para estimar esses efeitos para cada característica fenotípica. O efeito aditivo é definido como a distância dos homozigotos em relação à média e o efeito de dominância como a diferença entre a média dos parentais e o valor dos heterozigotos para o suposto QTL.

Análises foram realizadas para as características PN, P35, P41, P42, GP, CR, CA, C, PPet, PC, PA, R, GA, PP, Cl, Mo, Fig, Pul e Cor. Foi utilizada a opção "F2 QTL Analysis" do programa QTL EXPRESS para $1 \mathrm{QTL}$, incluindo no modelo sexo e família como efeitos fixos. Um QTL foi significativo quando excedeu o limiar de significância no genoma, baseado em um teste $\mathrm{F}$ convencional e apropriados graus de liberdade para a hipótese alternativa de presença de efeitos do QTL e a hipótese nula de ausência de QTL.

Se o teste estatístico inicial de 1 QTL excedeu o nível de significância foi então realizada uma série de análises baseadas no teste $\mathrm{F}$ e apropriados graus de liberdade para testar: 1) a interação entre QTL x sexo, para verificar se o QTL tem efeitos diferentes entre sexos, 2) interação QTL x família como evidência de que o QTL possa estar segregando em uma ou outra linha parental, ou seja, testa a pressuposição de que as linhagens utilizadas estão fixadas para alelos alternativos do QTL, 3) o modelo 
incluindo "imprinting" (efeito gamético) também foi avaliado para ver se a origem do alelo tem efeito no QTL, 4) características que apresentaram a presença de um QTL foram testadas para a presença de 2 QTLs. O modelo com 2 QTLs foi testado fixando um QTL e procurando outro a intervalos de $1 \mathrm{cM}$ ao longo do cromossomo. Localizado um segundo QTL, ele é fixado e move-se o primeiro QTL para posições próximas (também espaçadas em $1 \mathrm{cM}$ ). Este modelo foi testado por um teste $\mathrm{F}$ contra o modelo de 1 QTL (2 graus de liberdade no numerador).

\subsubsection{Análise de Meio-irmãos paternos}

Para esta análise, os animais F2 foram tratados como 3 grupos de meio-irmãos, isto é, toda a relação de parentesco adicional entre e dentro dos grupos de meioirmãos foi ignorada. Cada família de meio-irmãos inclui de 2 a 3 famílias de irmãos completos (família 1 tem 186 indivíduos F2, família 2 tem 289 F2 e família 3 tem 174 F2).

Neste modelo as análises são feitas entre os dois haplótipos de cada macho F1. Dentro de cada família de meio-irmãos é calculado o efeito de substituição do alelo do QTL ao longo do cromossomo, ou seja, é calculada a probabilidade de cada indivíduo F2 herdar cada gameta do macho em cada posição. Em análises simultâneas para os 3 machos, a regressão foi ajustada dentro de cada macho. Isto porque nem todos os machos são heterozigotos para o QTL e também a fase de ligação entre os alelos do QTL e alelos dos marcadores pode variar de macho para macho (Knott et al. 1996). Uma análise (estatística F) foi realizada a cada cM e a posição com um maior valor de F foi considerada a posição mais provável de um QTL. Quando um QTL foi detectado na análise contendo as 3 famílias, uma análise individual de cada uma das famílias foi realizada para inferir quais famílias estão segregando para o QTL.

\subsection{Nível de significância genômico}

O nível de significância genômico foi usado para detectar presença de QTL no genoma controlando a taxa de Erro Tipo I (falso positivo), pois para detectar QTLs um grande número de testes são necessários. O problema é que muitas vezes eles não são independentes, obtendo-se um nível de significância que pode gerar falsos QTLs. 
Para reduzir este problema foi calculado o nível de significância no cromossomo para obter o nível de significância genômico desejado, que deve ser proporcional à contribuição deste cromossomo para o comprimento total do genoma autossômico, como sugerido por De Koning et al. (1999) e Tuiskula-Haavisto et al. (2002). Esta probabilidade foi calculada pela seguinte equação seguindo a correção de Bonferroni:

$$
P_{(\text {genômico })}=1-\left(1-P_{(\text {comossomo })}\right)^{1 / r}
$$

Onde $r$ é a contribuição de um cromossomo, que é obtida dividindo-se o comprimento do cromossomo (ou segmento) testado pelo comprimento do genoma autossômico.

Utilizando esta probabilidade e a partir de 10.000 permutações realizadas na análise de QTL, foram obtidos empiricamente, segundo Churchill \& Doerge (1994), os valores de $F$ que correspondem aos níveis de significância sugestivo, 5 e 1\% de detectar QTLs em algum lugar em todo o genoma para cada característica.

\subsection{Intervalo de Confiança}

O intervalo de confiança (IC) do QTL foi obtido na opção "Bootstrap with resampling" do programa QTL EXPRESS, que usa esse método para calcular o IC empírico (95\%) da posição do QTL. 


\section{RESULTADOS E DISCUSSÃO}

\subsection{Extração de DNA}

Na fase inicial do projeto foram testados vários protocolos de extração de DNA para escolha de um método rápido, devido ao grande número de amostras, e que possibilitasse a obtenção de DNA de boa qualidade e em quantidade suficiente. $O$ protocolo de Hillel et al. (1989) (Anexo A) mostrou-se inadequado por ser demorado e consumir grandes quantidades de reagentes. O protocolo de Hillel modificado (Anexo B), apesar de utilizar menores quantidades de reagentes e ser mais rápido que o anterior, não resultou em DNA de boa qualidade. Optou-se então por testar o $D N A z o / \AA$, sendo necessária uma alteração (Anexo C) no protocolo recomendado pelo fabricante (Anexo D). O protocolo $D N A z o / \AA$ modificado (Anexo C) foi utilizado para a extração de DNA, sendo de modo geral eficiente, tanto pela qualidade do DNA extraído quanto pela rapidez do método. Para amostras que apresentaram problemas na extração com DNAzol ${ }^{\circledR}$, cerca de 10\%, resultando em DNA difícil de ser ressuspendido ou com baixa concentração (menos de $20 \mathrm{ng} / \mu \mathrm{L}$ ), foi utilizada a extração com proteinase $\mathrm{K}$ (Anexo $\mathrm{E})$.

Após a extração, todas a amostras tiveram sua concentração determinada por espectrofotometria e ajustada para $20 \mathrm{ng} / \mu \mathrm{L}$. As amostras padronizadas foram aplicas em gel de agarose $(1,0 \%)$ para verificação da qualidade do DNA, conforme pode ser observado nas Figuras 2 e 3. 


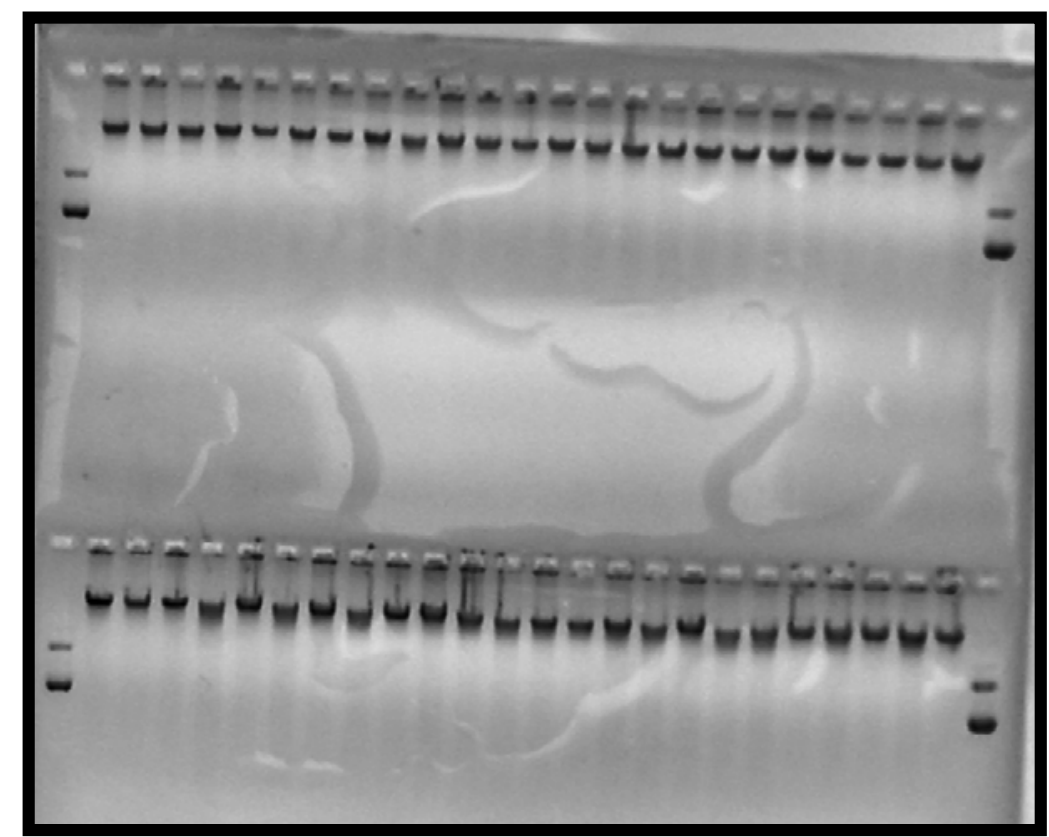

Figura 2 - Amostras de DNA extraídas e aplicadas em gel de agarose $(1,0 \%)$ sob eletroforese. Nas primeiras e últimas canaletas foi aplicado como padrão de concentração o plasmídeo pGEN4Z nas concentrações de 100 e 200 ng, respectivamente

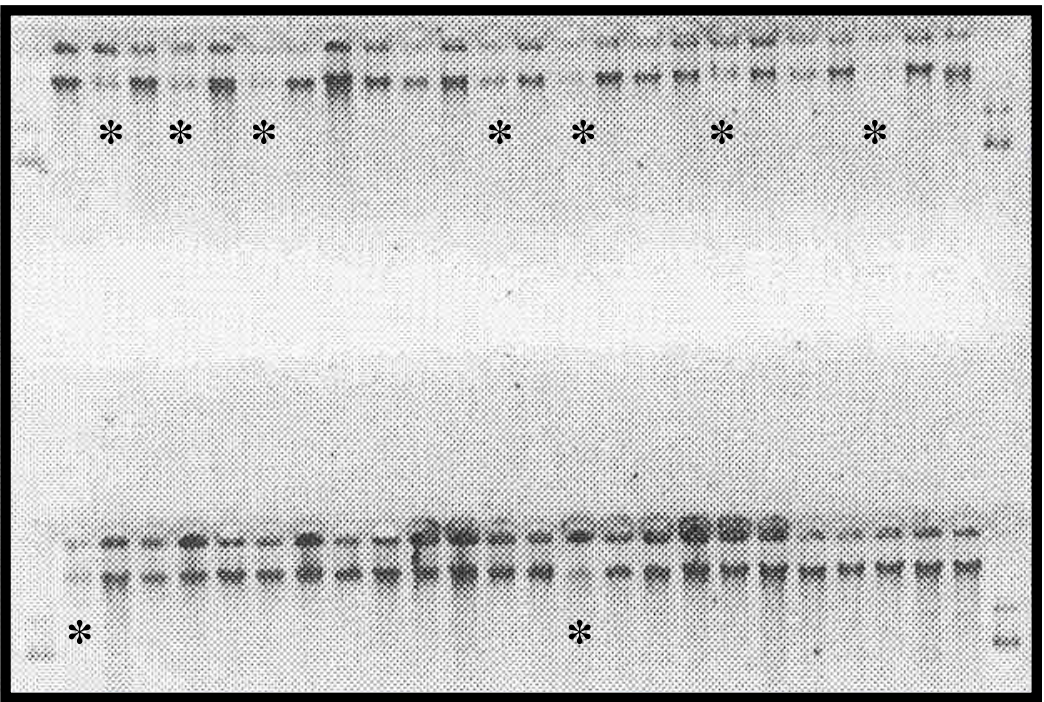

Figura 3 - Gel de agarose 1,0\% contendo DNA dos animais padronizado para concentração de $20 \mathrm{ng} / \mu \mathrm{L}$, de acordo com as leituras do espectrofotômetro. Nas primeiras e últimas canaletas foi aplicado como padrão de concentração o plasmídeo pGEN4Z nas concentrações de 100 e 200 ng, respectivamente

* Amostras que foram novamente diluídas utilizando o dobro de DNA e monitoradas nas amplificações dos marcadores. 
$\mathrm{Na}$ Figura 3 estão indicadas com asteriscos as amostras que, apesar de quantificadas em espectrofotômetro e diluídas para $20 \mathrm{ng} / \mu \mathrm{L}$, estavam com a concentração bem abaixo do estipulado. Para estas amostras o DNA original foi novamente diluído para uma concentração maior (40 ng/ $\mu \mathrm{L}$ ). Estas amostras foram monitoradas durante as amplificações, sendo aplicadas juntamente com outras amostras em agarose e submetidas à eletroforese para cada marcador amplificado, antes de serem genotipadas no seqüenciador.

\subsection{Amplificação por PCR}

Dos 80 marcadores testados 10 marcadores nunca produziram produtos de PCR (LEI194, LEI252, LEI193, ADL314, MCW289, MCW101, LEI198, ADL37, MCW36, GCT05), mesmo após algumas alterações na temperatura de anelamento e concentração de $\mathrm{Mg}^{++}$para melhorar a especificidade dos primers e a atividade e fidelidade da enzima.

$\mathrm{Na}$ otimização das condições de PCR existem várias alterações a serem testadas que demandam tempo, sendo mais interessante utilizar outros iniciadores nestas regiões sempre que possível. Este tipo de problema também foi encontrado por Zhu et al. (2001), que em seus estudos testaram diferentes temperaturas de anelamento e concentrações de $\mathrm{Mg}^{++}$, mas cerca de dois terços dos iniciadores não produziram produtos de PCR; os autores também optaram por abandoná-los e substituí-los.

As quantidades de $\mathrm{MgCl}_{2}$ utilizadas neste estudo foram superiores às recomendadas no site www.genome.iastate.edu. Entretanto, tentativas de redução na quantidade de $\mathrm{Mg}^{++}$, na maioria das vezes, comprometeu o resultado da amplificação. A redução na quantidade de $\mathrm{Mg}^{++}$, com o objetivo de aumentar a especificidade dos iniciadores, surtiu menores efeitos quando comparado com o ajuste da temperatura de anelamento.

Outra possível explicação para alguns iniciadores não produzirem produto de PCR foi o longo tempo de estocagem. Alguns destes iniciadores foram sintetizados em 1998 e os testes deste estudo foram iniciados em 2000. Apesar disso, a maioria 
$(87,5 \%)$ dos iniciadores apresentaram amplificação satisfatória após a otimização das condições de PCR.

As figuras 4, 5, 6 e 7 são imagens de géis de agarose 2,0\%, onde foram aplicados produtos de PCR da fase de otimização das condições de amplificação de alguns iniciadores.

ADL19

ADL101

ADL238

ADL251

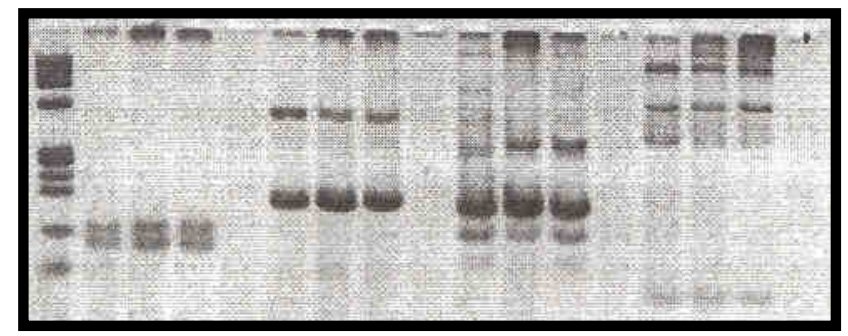

Figura 4 - Gel de agarose 2,0\% com testes das condições de amplificação. Apenas o marcador ADL 19 foi otimizado. Os demais marcadores apresentaram bandas inespecíficas, sendo necessários ajustes nas condições de PCR. Na primeira canaleta foi aplicado o padrão øX174 RF DNA/Hae III

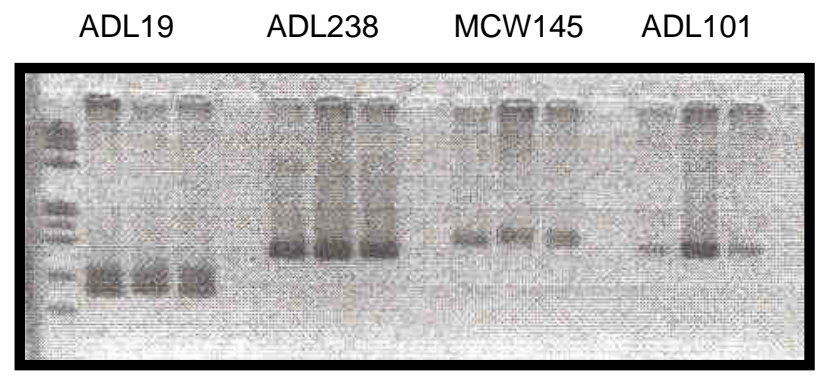

Figura 5 - Gel apresentando testes das condições de amplificação. Todos os marcadores foram otimizados apresentando apenas as bandas nos tamanhos esperados. Na primeira canaleta foi aplicado o padrão $ø$ X174 RF DNA/Hae III 


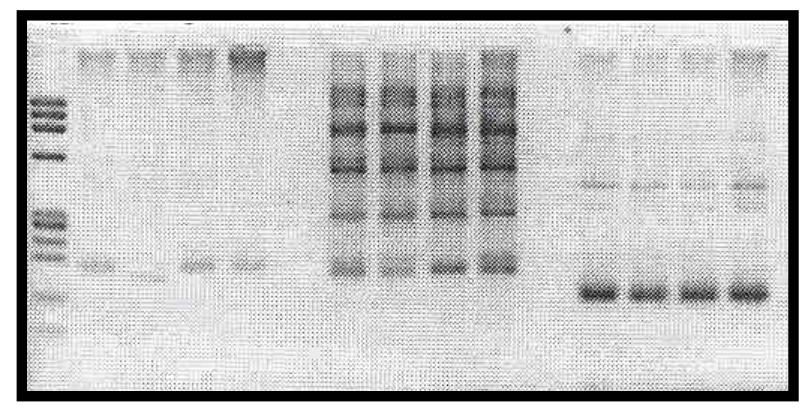

Figura 6 - Gel com testes das condições de amplificação. O marcador HUJ 01 apresentou amplificação específica e os demais marcadores necessitaram de alterações nas condições de amplificação, pois apresentaram bandas inespecíficas. $\mathrm{Na}$ primeira canaleta foi aplicado o padrão øX174 RF DNA/Hae III

ADL234 ABR328

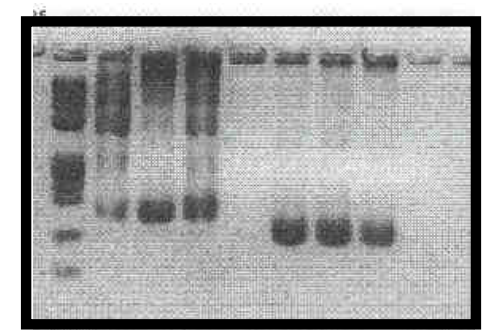

Figura 7 - Gel onde são apresentados o marcador ADL 234 com amplificação não específica e o marcador ABR 328 otimizado (apresentando banda específica de tamanho esperado). Na primeira canaleta foi aplicado o padrão øX174 RF DNA/Hae III

Nas figuras 8, 9, 10, 11 e 12 são apresentados géis onde são testadas várias amostras de cada marcador, tentando com isso evitar falhas na genotipagem, ocasionadas por má qualidade de produto amplificado. Para cada amplificação foi verificado o tamanho do fragmento esperado e a presença de bandas inespecíficas. A identificação de bandas inespecíficas foi importante para que, no momento da montagem das placas de genotipagem, quando foi preparada uma mistura do produto amplificado de 3 a 4 marcadores, se tivesse o cuidado de agrupar as amplificações inespecíficas somente com amplificações de marcadores com outro tipo de fluorescência. Esse cuidado foi importante para não comprometer a genotipagem de nenhum dos marcadores e evitar o descarte das amplificações que apresentassem bandas inespecíficas. 


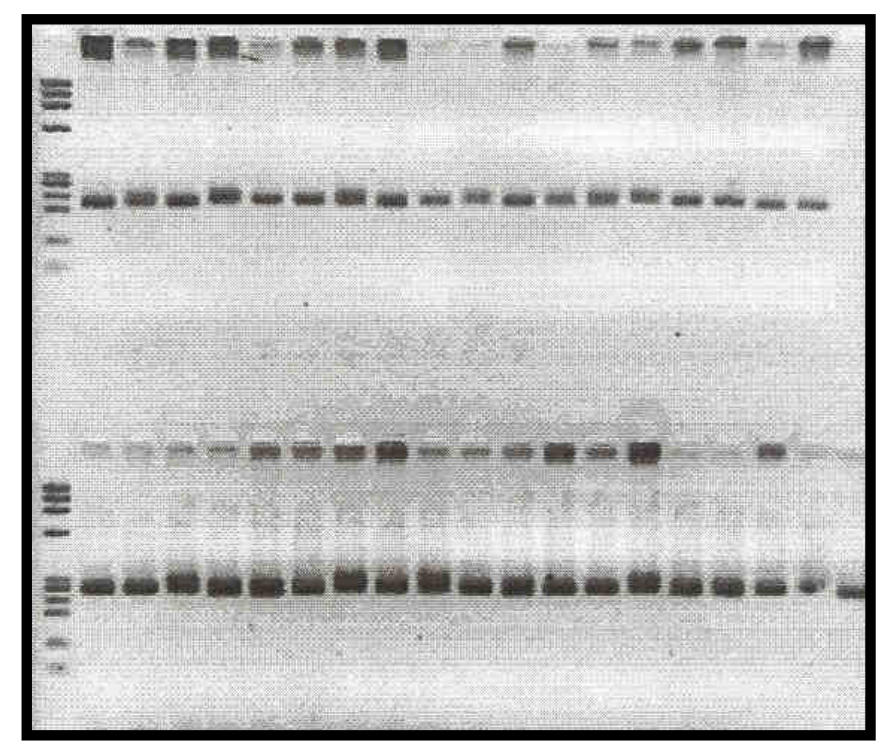

LEI79 - 200 a 234 pb

MCW218 - 258 a $282 \mathrm{pb}$

Figura 8 - Gel de agarose 2,0\% com material amplificado dos marcadores LEI 79 e MCW 218. Na primeira canaleta foi aplicado o padrão øX174 RF DNA/Hae III

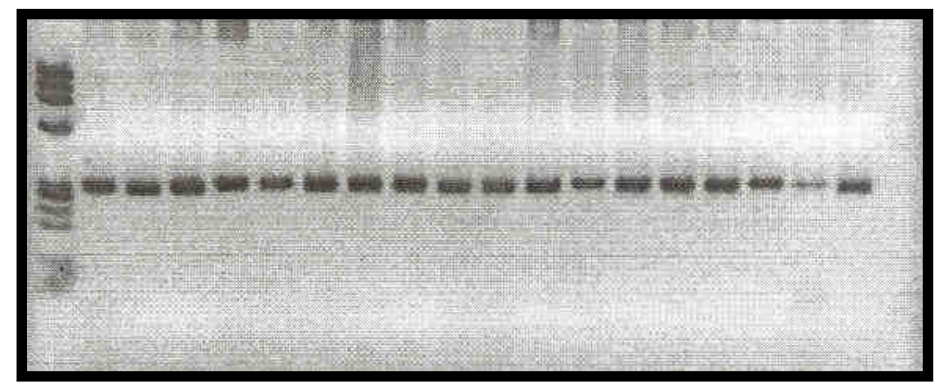

LEI106 - 288 a $300 \mathrm{pb}$

Figura 9 - Gel de agarose 2,0\% com material amplificado do marcador LEI106. Na primeira canaleta foi aplicado o padrão øX174 RF DNA/Hae III

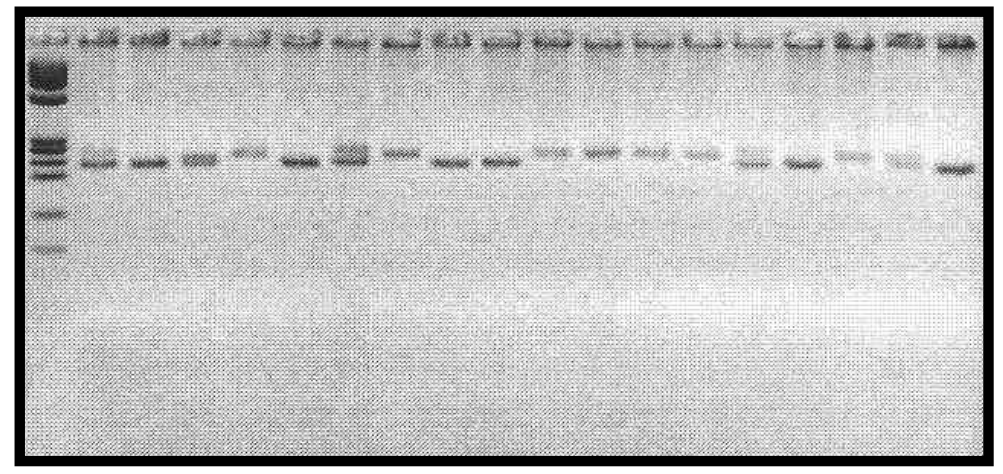

LEI91 - 238 a 264 pb

Figura 10 - Gel de agarose 2,0\% com material amplificado do marcador LEI91. Na primeira canaleta foi aplicado o padrão øX174 RF DNA/Hae III 


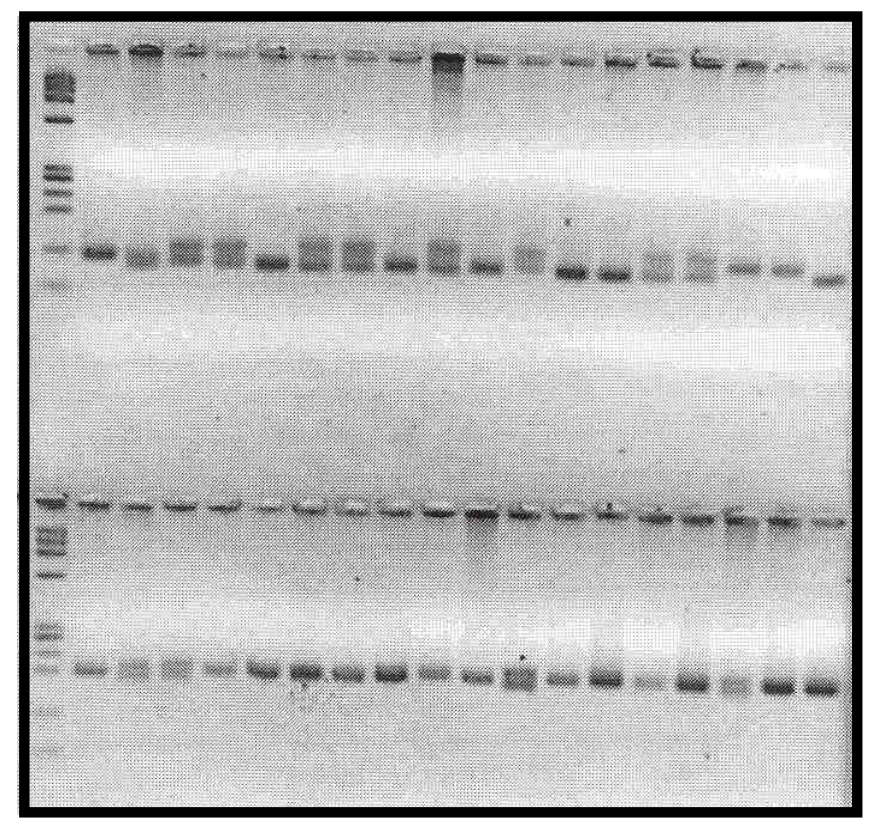

ADL19 - 84 a $124 \mathrm{pb}$

MCW145 - 170 a $210 \mathrm{pb}$

Figura 11 - Gel de agarose 2,0\% com material amplificado dos marcadores ADL19 e MCW145. Na primeira canaleta foi aplicado o padrão øX174 RF DNA/Hae III

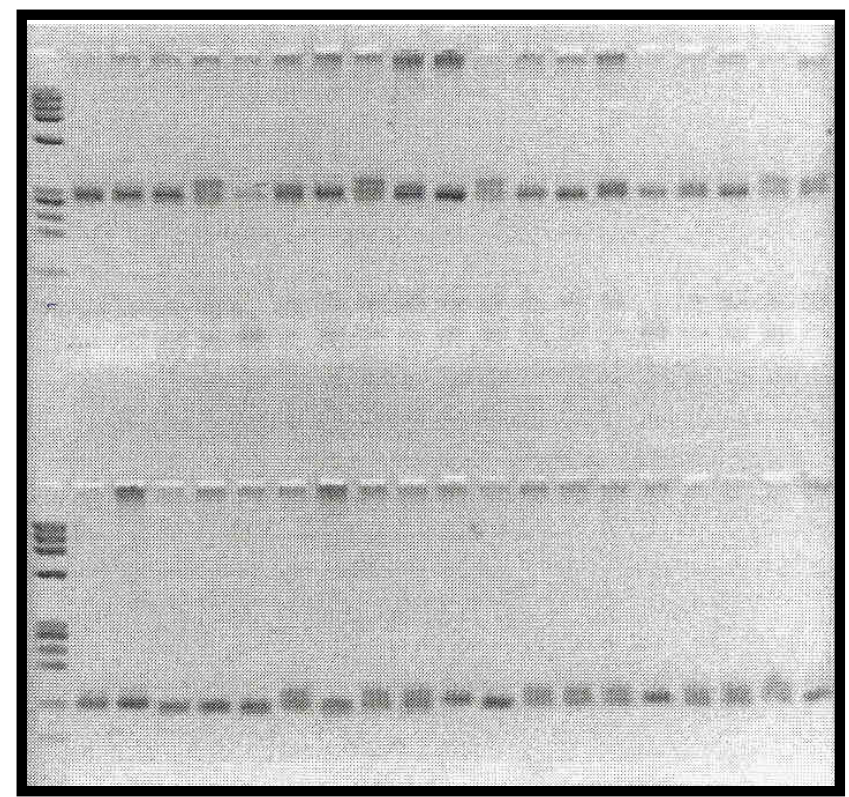

LEI134 - 294 a 300 pb

MCW107 - 90 a $130 \mathrm{pb}$

Figura 12 - Gel de agarose 2,0\% com material amplificado dos marcadores LEI134 e MCW107. Na primeira canaleta foi aplicado o padrão øX174 RF DNA/Hae III 


\subsection{Seleção de marcadores informativos e genotipagem}

Após a otimização das condições de PCR, os marcadores otimizados foram genotipados para os 27 animais F1 com o objetivo de selecionar marcadores informativos. Dos 70 marcadores testados 20 (MCW254, MCW313, MCW177, MCW255, LEl168, MCW318, ADL251, ADL160, MCW112, ROS76, ADL198, MCW23, HUJ003, LEI217, GCT01, LEI31, LEI209, LEI84, HUJ01 e UMA1.125) não foram informativos ou foram informativos em poucas famílias, e três marcadores (UMA1.019, ADL252 e LEI246) foram inconsistentes na genotipagem.

Para a seleção de marcadores informativos foi utilizada a classificação sugerida por Zhu et al. (2001), os marcadores foram considerados informativos quando pelo menos um F1 foi heterozigoto e o outro F1 teve um genótipo diferente para o loco.

Segundo Crooijmans et al. (1996), os marcadores podem ser altamente polimórficos em uma linha e serem monomórficos em outra, o que enfatiza a necessidade de análises preliminares baseadas no polimorfismo dentro das linhas que serão utilizadas em estudos de ligação e associação. Segundo Zhu et al. (2001), em populações não endogâmicas grande parte dos locos não são informativos, o que reduz o poder de detectar QTLs. Nesse caso, a marcadores mais informativos, visando um maior número de famílias que proporcionem informação em determinado loco, pode aumentar este poder.

Zhu et al. (2003), estudando QTLs para resistência a coccidiose em cruzamento não endogâmico entre linhagens de frangos de corte, encontraram diferenças na análise de QTLs dependendo do grau de informação dos marcadores nas famílias utilizadas. Apesar das linhagens utilizadas no estudo serem diferentes para a característica resistência a coccidiose, os indivíduos escolhidos em cada linha poderiam não necessariamente ser diferentes. Não foi realizada genotipagem prévia dos animais e assim alguns marcadores podiam não ser informativos para as famílias. Quando os autores utilizaram 12 famílias na análise, sendo que em 8 delas os marcadores não eram informativos, o LOD para o QTL foi de 1,5. Refazendo a análise com apenas 4 famílias em que os marcadores eram informativos o LOD passou para 3,46 , identificando assim um QTL significativo para contagem de oocistos a $252 \mathrm{cM}$ no cromossomo 1. Os autores concluíram que o poder de detecção de QTLs pode ser 
significativamente aumentado se as famílias não informativas forem removidas da análise. Entretanto, este procedimento pode aumentar o erro tipo I (aceitar como verdadeiro um falso QTL).

Os resultados obtidos no presente estudo indicam que alguns dos marcadores não são informativos para algumas famílias, o que pode reduzir o poder de detecção de QTLs. Nesse caso, foram escolhidos os marcadores informativos no maior número famílias para serem utilizados a genotipagem seletiva, visando um maior poder de detecção de QTLs e maior acurácia no mapa de ligação. Na Figura 13 é apresentada uma imagem da genotipagem realizada no seqüenciador MegaBACE, onde é mostrado o genótipo de um casal parental e um indivíduo F1 heterozigoto. Segundo Cheng et al. (1995), na construção do mapa de ligação e detecção de QTLs é necessária a utilização de marcadores com alta heterozigosidade nos animais F1 e um grande número de marcadores distribuídos em intervalos regulares, de no máximo 20 cM.

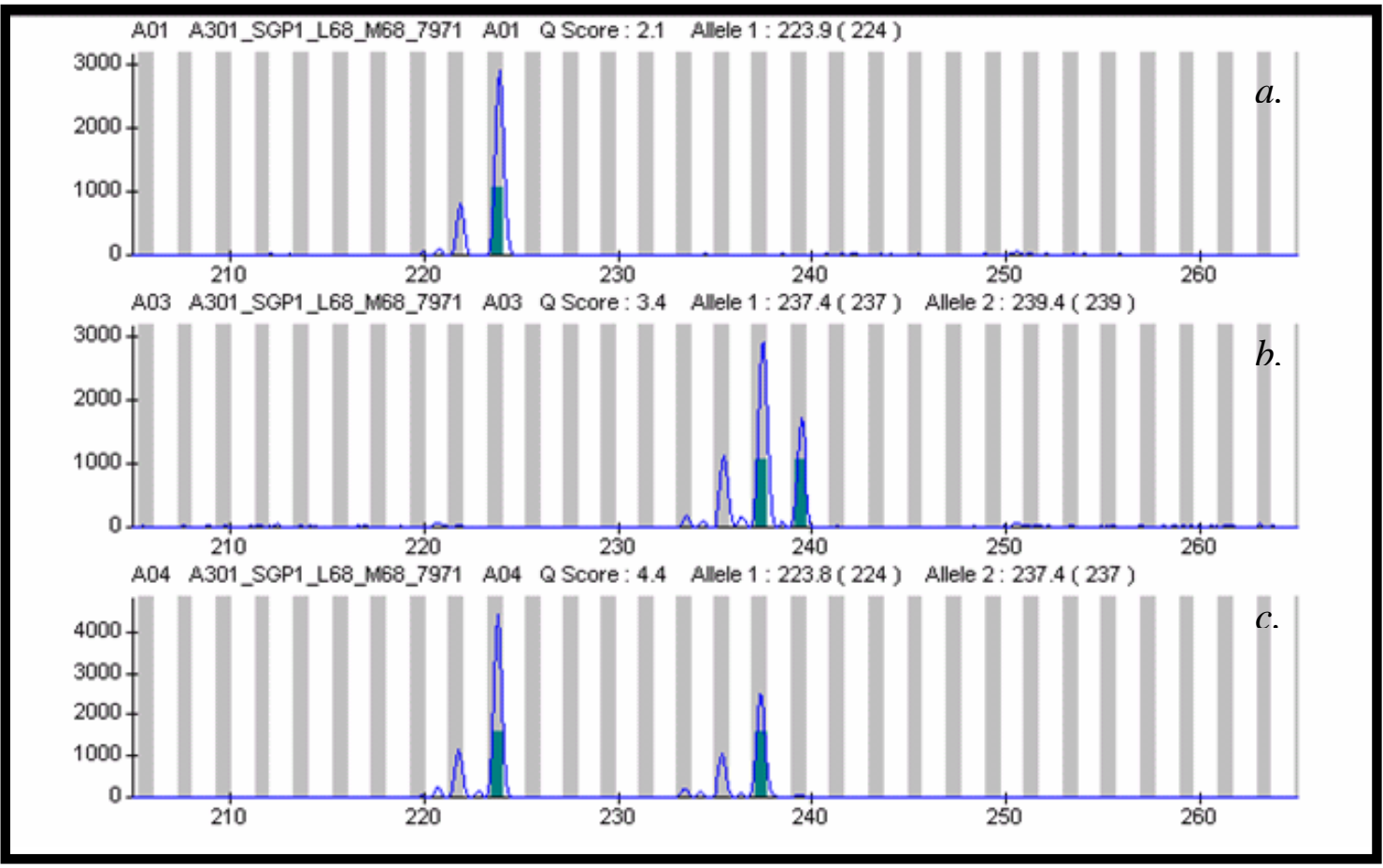

Figura 13 - Imagem da genotipagem realizada no seqüenciador MegaBACE com genótipos de um casal parental (a. genótipo 224/224 e b. 237/239) e de um individuo F1 heterozigoto (c. 224/237) para o marcador LEI68. 


\subsection{Genotipagem Seletiva}

A genotipagem seletiva foi utilizada como medida de redução de custos, pois segundo Darvasi \& Soller (1992), Kirkpatrick et al. (1998), Bovenhuis \& Spelman (2000), a genotipagem seletiva é uma estratégia para reduzir a quantidade de genotipagens, através da genotipagem preliminar de indivíduos dos extremos fenotípicos da população, para a identificação de marcadores que possivelmente estejam associados a QTLs.

\subsubsection{Seleção dos animais}

Os animais da geração F2, totalizando 2.063 indivíduos F2 do cruzamento TC, foram avaliados para 19 características relacionadas a desempenho e qualidade de carcaça. Foram eliminados dados discrepantes "outliers" (observações com mais de 4 desvios-padrão da média) As médias, desvios-padrão e valores mínimos e máximos das 19 características para os 2063 animais F2 do cruzamento TC (Tabela 9).

Foram também descartados 108 animais F2 cujo sangue da mãe F1 não estava disponível, e dados de indivíduos cujo sangue não estava disponível, restando 1860 aves, divididas em 925 fêmeas e 934 machos. E cada grupo teve o peso vivo aos 42 dias de idade (P42) ajustado para o efeito de incubação (P42 AJU). Isto foi feito para evitar o efeito de sexo e efeitos ambientais. Após o ajuste do P42, os animais foram selecionados dentro de cada família de mãe F1 (20 famílias). Este procedimento é recomendado por Hillel (1997) e Muranty et al. (1997). Estes autores afirmam que em populações não endogâmicas, se a seleção de animais para genotipagem seletiva for feita nos extremos da população, muitos animais de algumas famílias e nenhum indivíduo de outras famílias pode ser selecionado, devido ao efeito de família.

Nas Tabelas 10 e 11 são apresentadas as correlações fenotípicas entre P42 e as principais características de desempenho e carcaça.

Darvasi \& Soller (1992), Muranty et al. (1997) e Bovenhuis \& Spelman (2000) afirmaram que, ao se aplicar a estratégia de genotipagem seletiva, pode-se aumentar significativamente o poder de detecção de QTLs para a característica em questão. Entretanto, o benefício da redução de genotipagens diminui com o aumento no número de características que estão sendo estudadas, especialmente se a correlação entre 
elas for baixa. Quando as características não são correlacionadas, os extremos fenotípicos de uma característica e de outra podem ser diferentes, podendo-se ter uma redução no poder estatístico para detectar QTLs. Contudo, o poder de detecção de QTL é levemente reduzido se as características são altamente correlacionadas. No presente estudo, como pode ser observada nas Tabelas 10 e 11 a maioria das características avaliadas é bem correlacionada com o P42. Que foi a característica escolhida para seleção dos animais na genotipagem seletiva, esperando-se com isso que não ocorram, ou que sejam mínimas, as perdas no poder de detecção dos QTLs para as demais características.

A proporção de indivíduos F2 selecionados para a genotipagem seletiva foi de 9\% dos indivíduos F2, totalizando 170 animais (86 fêmeas e 84 machos), sendo 4,5\% de indivíduos mais leves e 4,5\% mais pesados dentro de cada família. As médias e erros-padrão do P42 AJU nos grupos leve e pesado foram: 801,5 \pm 93,8 g e 1328,5 \pm 127,8 g, respectivamente. Segundo Darvasi \& Soller (1992), uma proporção ótima de seleção na genotipagem seletiva para pequenos animais (como aves) pode estar entre 5 e $10 \%$ do total de indivíduos da população.

Tabela 9. Médias, desvios-padrão e valores máximos e mínimos para 19 características avaliadas nos animais F2 do cruzamento TC

\begin{tabular}{lccccc}
\hline \multicolumn{1}{c}{ Variável } & $\mathbf{N}$ & Média & Desvio-padrão & Valor mínimo & Valor máximo \\
\hline PN (g) & 2061 & 44.592 & 4.631 & 29.7 & 59.3 \\
P35 $(\mathrm{g})$ & 2062 & 819.158 & 136.757 & 436 & 1.341 \\
P41 $(\mathrm{g})$ & 2063 & 1043.479 & 183.133 & 407 & 1.698 \\
P42 $(\mathrm{g})$ & 2063 & 1005.710 & 180.542 & 402 & 1.688 \\
C & 2063 & 654.329 & 126.329 & 234 & 1.175 \\
PC (g) & 2062 & 216.474 & 43.880 & 67 & 354 \\
Ppeit (g) & 2061 & 162.276 & 33.882 & 55 & 303 \\
PP (g) & 2061 & 40.747 & 8.683 & 16 & 34 \\
R (g) & 2062 & 192.113 & 38.226 & 75 & 55 \\
GA (g) & 2062 & 17.072 & 7.828 & 0 & 140 \\
PA (g) & 2063 & 83.171 & 14.110 & 31 & 50 \\
Fig (g) & 2060 & 26.963 & 5.052 & 12 & 15 \\
Cor (g) & 2059 & 6.657 & 1.645 & 2 & 48 \\
Mo (g) & 2060 & 25.156 & 4.664 & 13 & 16 \\
Pul (g) & 2059 & 8.222 & 2.246 & 2 & 220 \\
Cl (cm) & 2059 & 156.653 & 15.734 & 104 & 495 \\
GP (g) & 2051 & 226.223 & 65.991 & 4 & 1.176 \\
CR (g) & 2061 & 602.769 & 128.620 & 116 & 7,917 \\
CA & 2031 & 2.816 & 1.819 & 0.832 & \\
\hline
\end{tabular}

Peso ao nascer (PN), peso aos 35 (P35), 41 (P41) e 42 (P42) dias de idade; ganho de peso (GP), consumo de ração (CR) e conversão alimentar (CA) dos 35 aos 41 dias de idade, peso de pulmão (Pul), peso de fígado (Fig), peso de coração (Cor), peso de moela (Mo), comprimento do intestino (Cl), peso da carcaça (C), peso de peito (PPeit), peso de coxas (PC), peso da carcaça residual (R), peso de asas (PA), peso da gordura abdominal (GA), peso de pés (PP). 
Tabela 10. Correlações fenotípicas entre P42 e características de desempenho de 2.063 animais F2 do cruzamento TC

\begin{tabular}{lccccccc}
\hline Variável & P42 & P35 & P41 & GP & CR & CA & Cl \\
\hline P42 & 1 & 0,86 & 0,99 & 0,66 & 0,58 & $-0,09$ & 0,44 \\
P35 & & 1 & 0,86 & 0,38 & 0,47 & 0,01 & 0,47 \\
P41 & & & 1 & 0,86 & 0,59 & $-0,11$ & 0,43 \\
GP & & & & 1 & 0,59 & $-0,32$ & 0,23 \\
CR & & & & & 1 & $-0,04$ & 0,32 \\
CA & & & & & & 1 & $-0,04$ \\
Cl & & & & & & & 1 \\
\hline
\end{tabular}

Peso aos 35 (P35), 41 (P41) e 42 (P42) dias de idade; ganho de peso (GP), consumo de ração (CR) e conversão alimentar (CA) dos 35 aos 41 dias de idade, comprimento do intestino (CI).

Tabela 11. Correlações fenotípicas entre P42 e características de carcaça de 2.063 animais F2 do cruzamento TC

\begin{tabular}{cllllllll}
\hline Variável & P42 & \multicolumn{1}{c}{ PPeit } & \multicolumn{1}{c}{ PC } & C & \multicolumn{1}{c}{ GA } & Cor & Fíg \\
\hline P42 & 1 & 0,79 & 0,87 & 0,84 & 0,61 & 0,48 & 0,68 \\
PPeit & & 1 & 0,83 & 0,95 & 0,53 & 0,51 & 0,59 \\
PC & & & 1 & 0,90 & 0,62 & 0,50 & 0,67 \\
C & & & & 1 & 0,61 & 0,55 & 0,64 \\
GA & & & & & 1 & 0,32 & 0,48 \\
Cor & & & & & & 1 & 0,42 \\
Fíg & & & & & & & 1 \\
\hline
\end{tabular}

Peso aos 42 dias de idade (P42); peso de peito (PPeit), peso de coxas (PC), peso da carcaça residual (R), peso de asas (PA), peso da gordura abdominal (GA), peso de fígado (Fig), peso de coração (Cor).

\subsubsection{Genotipagem:}

Trinta e três marcadores foram utilizados na genotipagem seletiva tentando cobrir todo o cromossomo 1, com o menor espaçamento possível. Em regiões onde havia vários marcadores, optou-se pelos que se apresentaram informativos para um maior número de famílias. Contudo, onde não havia muitos marcadores, utilizou-se os marcadores disponíveis, mesmo quando eles não eram informativos para a maioria das famílias.

Foram utilizados na genotipagem seletiva 33 marcadores com espaçamento médio de 17,3 cM (distâncias segundo os mapas CN, C, E e W), mas que variou de 1 a $38 \mathrm{cM}$, cobrindo $575 \mathrm{cM}$ (92\%) dos $565 \mathrm{cM}$ totais do cromossomo 1. 


\subsubsection{Teste de Qui-quadrado}

Após a genotipagem dos 170 animais para cada um dos 33 marcadores foi realizado o teste de Qui-quadrado, testando se as freqüências alélicas foram iguais entre o grupo de animais leves e pesados para cada um dos marcadores. Esta análise é considerada uma indicação preliminar de ligação entre o marcador e o QTL, conforme sugerido por Kirkpatrick et al. (1998) e Moody et al. (1999).

$\mathrm{Na}$ Tabela 12 são apresentados os marcadores utilizados na genotipagem seletiva com número de famílias em que esses marcadores foram informativos e o resultado da análise do teste de Qui-quadrado, indicando se os marcadores estão ou não associados locos que afetam o P42.

Na Figura 14 é apresentado um gráfico com a transformação $(\log (1 / P))$ dos valores de $\mathrm{P}$, para melhor visualização dos marcadores potencialmente associadas a QTLS.

A partir desta análise preliminar, 12 marcadores (ADL 234, MCW 297, LEI 146, ADL 150, LEI 174, LEI 71, MCW58, LEI 160, LEI 106, LEI 169, LEI 79 e MCW 145) foram significativamente $(P<0,10)$ ligados a QTLs para $P 42$ AJU.

Na Figura 14 é possível identificar 3 regiões no cromossomo 1 em que possivelmente poderão ser encontrados marcadores ligados a QTLs em uma análise mais detalhada. Uma região entre os marcadores ADL 234 (151 cM) e LEl71 (243 cM) (região A), outra em torno do marcador LEl160 a 309 cM (região B) e por último uma região entre os marcadores LEl 169 (400 cM) e MCW145 (455cM) (região C). As distâncias utilizadas na Figura 13 seguem as posições dos marcadores nos mapas CN, W, C, ou E, sendo possível encontrar diferenças nas distâncias entre marcadores no mapa de ligação da população em estudo.

Alguns estudos encontraram QTLs ligados a desempenho e carcaça no cromossomo 1. Van Kaam et al. (1999a e 1999b) encontraram um QTL significativo a $235 \mathrm{cM}$ para consumo de ração de 23 a 48 dias de idade, associado ao marcador MCW58. Encontraram também 3 QTLs sugestivos, um para porcentagem de carcaça a 466 cM próximo ao marcador LEI 79, um para ganho de peso entre 23 e 48 dias de idade e outro para peso corporal aos 48 dias de idade. Os dois últimos na região de 235 a 240 cM, associados aos marcadores LEI71 e MCW58. 
Tabela 12. Marcadores utilizados na genotipagem seletiva, posição segundo o mapa CN,

E C e W, número de famílias informativas e resultado do teste de Qui-quadrado

\begin{tabular}{|c|c|c|c|}
\hline Marcador & Posição (cM) & $\begin{array}{l}\mathrm{N}^{0} \text { de famílias em que o } \\
\text { marcador foi informativo }\end{array}$ & Probabilidade do $\chi^{2}$ \\
\hline MCW248 & 12 & 10 & 0,856 (NS) \\
\hline MCW168 & 24 & 5 & 0,628 (NS) \\
\hline LEI209 & 54 & 8 & 0,449 (NS) \\
\hline GCT06 & 66 & 9 & 0,940 (NS) \\
\hline MCW11 & 91 & 5 & 0,576 (NS) \\
\hline MCW106 & 94 & 9 & 0,653 (NS) \\
\hline ADL19 & 122 & 16 & 0,337 (NS) \\
\hline ADL234 & 151 & 12 & 0,017(Associado) \\
\hline MCW297 & 162 & 14 & 0,022(Associado) \\
\hline LEI146 & 169 & 16 & 0,001 (Associado) \\
\hline LEl174 & 205 & 8 & 0,057(Associado) \\
\hline ADL150 & 209 & 13 & 0,001 (Associado) \\
\hline MCW58 & 241 & 10 & 0,021(Associado) \\
\hline LEI71 & 243 & 13 & 0,002(Associado) \\
\hline LEI101 & 259 & 15 & $0,153(N S)$ \\
\hline MCW218 & 270 & 11 & 0,277 (NS) \\
\hline LEI108 & 300 & 10 & 0,328 (NS) \\
\hline LEI160 & 309 & 16 & 0,002(Associado) \\
\hline LEI88 & 316 & 11 & 0,399 (NS) \\
\hline MCW200 & 330 & 12 & 0,521 (NS) \\
\hline LEI139 & 356 & 11 & 0,143 (NS) \\
\hline LEI91 & 366 & 8 & 0,109 (NS) \\
\hline LEI169 & 400 & 6 & 0,091(Associado) \\
\hline MCW283 & 413 & 14 & $0,502(\mathrm{NS})$ \\
\hline LEI106 & 414 & 10 & 0,007(Associado) \\
\hline LEI107 & 424 & 16 & $0,324(N S)$ \\
\hline LEI79 & 445 & 11 & 0,001(Associado) \\
\hline MCW145 & 455 & 14 & 0,007(Associado) \\
\hline ABR328 & 477 & 6 & 0,205 (NS) \\
\hline ADL238 & 497 & 8 & 0,527 (NS) \\
\hline ADL101 & 500 & 8 & 0,445 (NS) \\
\hline LEI134 & 527 & 5 & 0,451 (NS) \\
\hline MCW107 & 565 & 10 & 0,314 (NS) \\
\hline
\end{tabular}

Marcadores em negrito foram associados a QTLs.

NS - Associação não significativa.

Tatsuda \& Fujinaka (2001) encontraram 1 QTL para peso a 13 e 16 semanas de idade, a 220 cM, entre os marcadores LEI174 e LEI71. Estes autores encontraram somente uma região associada a QTL, isso porque eles utilizaram apenas 10 marcadores cobrindo a metade inicial do cromossomo 1, sendo o marcador LEI 910 último marcador avaliado, localizado a aproximadamente $366 \mathrm{cM}$. Estes autores não 
encontraram QTL na região do marcador LEI160 que foi ligado significativamente a QTL na análise preliminar realizada no presente estudo. Isso pode sugerir que a população desenvolvida por Tatsuda \& Fujinaka (2001) não estava segregando para o QTL ou a ligação QTL x marcador LEI160 seja falsa positiva no presente estudo, pois nenhum QTL foi anteriormente localizado nesta região.

Sewalem et al. (2002) encontraram 5 QTLs significativos a 5\% considerando todo o genoma, em uma população originada do cruzamento aves de corte e de postura. Desses, dois QTLs foram para peso vivo a 3 semanas, um entre os marcadores LEI68 e LEI146, a 169 cM, e outro entre os marcadores ADL183 e ROS25, a $505 \mathrm{cM}$. Outros dois QTLs foram significativos para peso a 6 semanas, um entre os marcadores LEI146 e MCW18, a 184 cM, e outro entre os marcadores ADL183 e ROS25, a $490 \mathrm{cM}$. O quinto QTL para peso a 9 semanas foi identificado entre os marcadores LEI106 e LEI79, a 428 cM. Esses autores ainda identificaram 1 QTL sugestivo para peso a 9 semanas entre os marcadores MCW10 e ADL188, a 88 cM.

Ikeobi et al. (2002) identificaram QTLs para deposição de gordura no cromossomo 1, utilizando a mesma população que Sewalem et al. (2002). Foi encontrado um QTL significativo a $5 \%$ considerando todo o genoma entre os marcadores ADL188 e LEI68, a 150 cM; outro QTL sugestivo para peso da gordura subcutânea ajustado para peso corporal foi identificado entre os marcadores ADL183 e ROS25, a $478 \mathrm{cM}$. 


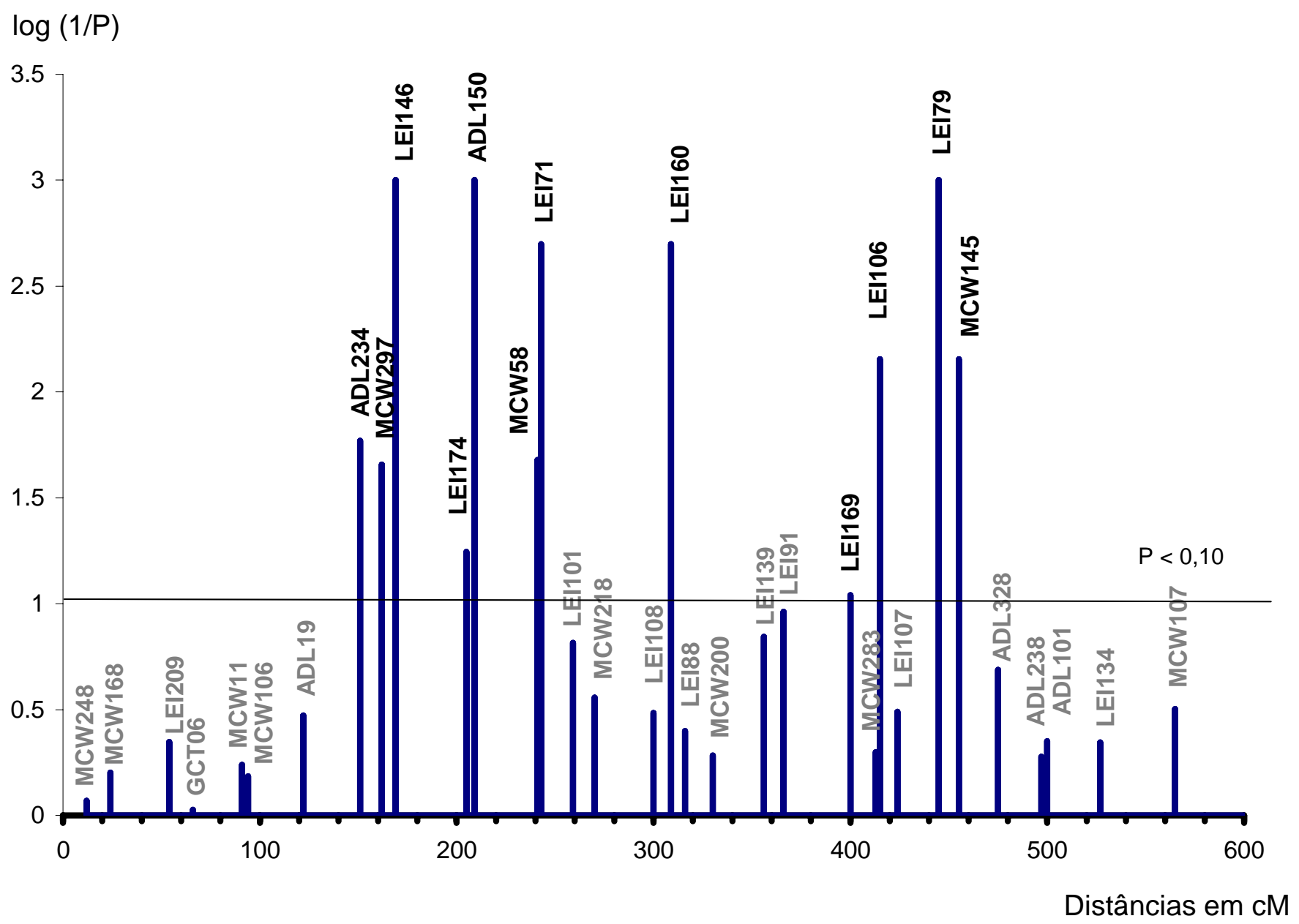

Figura 14 - Representação gráfica de todos os marcadores testados na genotipagem seletiva. Marcadores em preto foram associados $(P<0,10)$ a QTLs. Distâncias segundo CN, W, C e E 
Os resultados apresentados neste estudo preliminar reforçam alguns resultados obtidos nos estudos apresentados acima, pois os marcadores LEI146, LEI174, LEI71 e MCW58 (região A - de 151 a 241 cM) e os marcadores LEI79 e LEI106 (região C - de 398 a 455 cM) já foram associados a QTLs anteriormente em outras populações. Outro fato que reforça a possibilidade de presença de QTLs nessas regiões é que, mesmo avaliando outros marcadores, os autores acima citados encontraram QTLs próximos as regiões encontradas nesta análise preliminar.

Os marcadores identificados como associados a QTLs na genotipagem seletiva foram genotipados para 7 famílias completas, juntamente com 14 marcadores adicionais para a redução do espaçamento entre os marcadores nas regiões associadas.

As famílias utilizadas na genotipagem completa e mapeamento de QTL foram selecionadas a partir dos marcadores associados a QTL na genotipagem seletiva. Foram selecionadas as famílias $7816,7749,7709,7810,7978,7765,7971$, pois apresentaram um maior número de marcadores informativos. No processo de seleção foi dada preferência a famílias aparentadas, que tivessem o macho F1 em comum. Foram selecionados 3 machos (7716 com 2 famílias, 7769 com 3 famílias e 7822 com 2 famílias) para obter um maior número de indivíduos F2 meio-irmãos, para a análise de mapeamento de QTL utilizando delineamento de meio-irmãos paternos.

Na figura 15 é apresentado um gráfico indicando as posições dos 26 marcadores utilizados para genotipar 653 animais F2 e para o mapeamento de QTLs. 


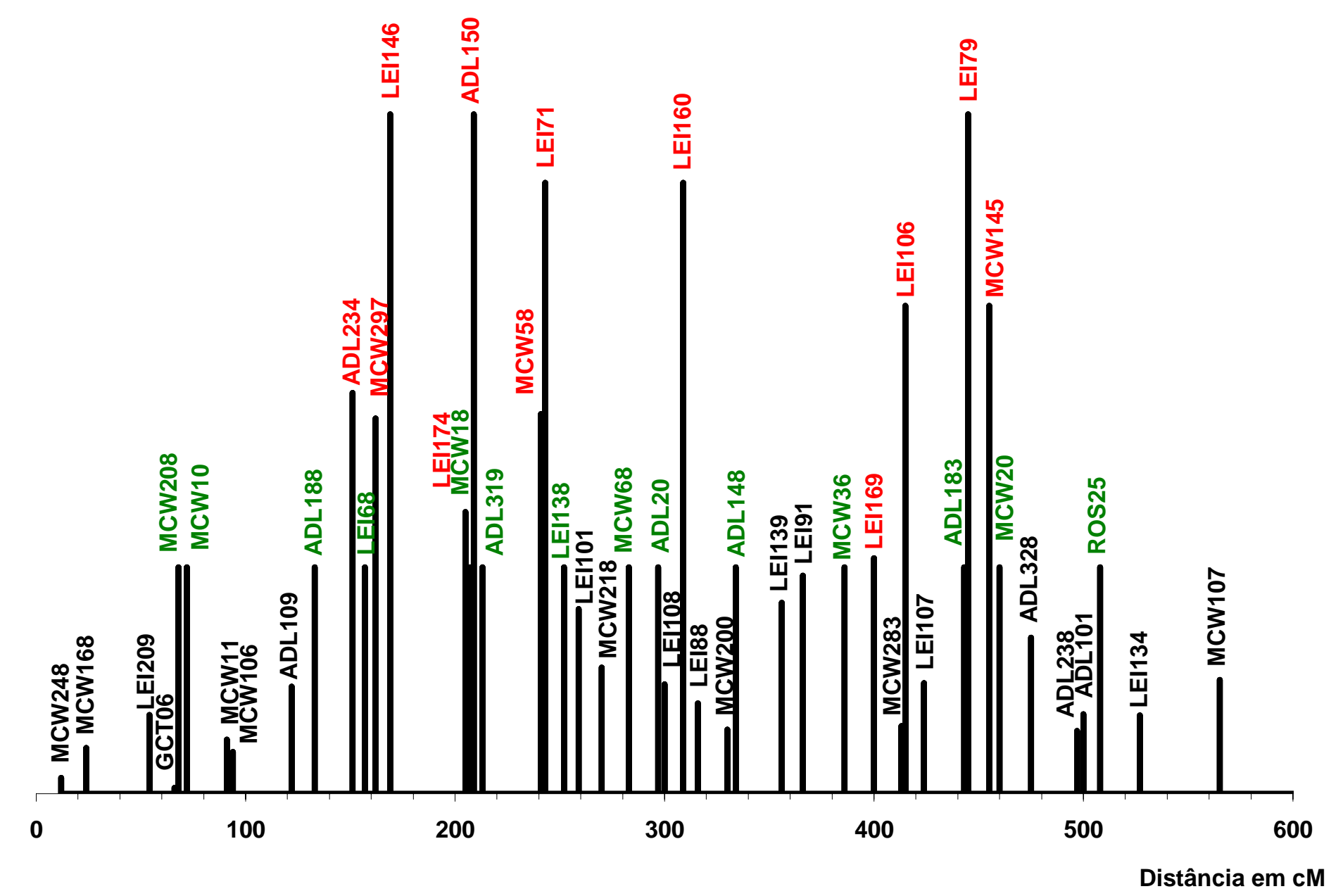

Figura 15 - Representação gráfica das distâncias entre marcadores segundo o os mapas CN, W, C e E. Marcadores em vermelho foram associados a QTLs na genotipagem seletiva e os marcadores flanqueadores estão em verde. Marcadores em vermelho e verde foram genotipados para 653 F2 e utilizados para construção do mapa de ligação e no mapeamento de QTLs 


\subsection{Mapa de ligação}

O mapa de ligação da população foi construído utilizando o programa CRIMAP, a partir dos genótipos de 653 animais F2 para 26 marcadores. Inicialmente foi utilizada a opção TWO POINT do programa onde são apresentadas as frações de recombinações dos marcadores dois a dois. Primeiramente foi utilizado nesta opção um LOD igual a 3, para verificar se havia ligação entre os marcadores. Apenas os marcadores MCW10, MC208 não tiveram suas frações de recombinação calculadas em relação aos demais marcadores. Mas a fração de recombinação entre eles foi 0,03 com um LOD $=100,75$. Como é sabido que estes dois marcadores estão localizados no cromossomo 1 baseado em outros mapas (CN, C, E, W), mas com uma grande distância em relação ao restante dos marcadores utilizados, cerca de $48 \mathrm{cM}$. Foi então reduzido o valor do LOD para 2 e a fração de recombinação para o marcadores MCW208 e ADL188 foi de 0,42 com um LOD igual a 2,91. Logo, todos os marcadores mostraram ligação significativa (LOD > 2), isso indica que a hipótese dos marcadores estarem ligados é 100 vezes mais verossímil (provável) que a de não estarem ligados. Os marcadores MCW10 e MCW208 foram incluídos neste estudo depois que Sewalen et al. (2002) mapearam QTL na região próxima a estes marcadores, como segurança para que não fossem perdidos possíveis QTLs nesta região. Uma vez que na genotipagem seletiva não foi encontrado marcador associado a P42AJU nesta região.

A opção BUILD foi utilizada para ordenar os marcadores. Para iniciar o ordenamento foi utilizado um par de marcadores altamente informativo e com maior valor de LOD, e os demais marcadores foram inseridos um a um. Vinte e quatro marcadores foram inseridos desta maneira. Apenas os marcadores ADL183 e MCW36 não puderam ser inseridos no grupo. Foi preciso dividir os marcadores em subgrupos, nos quais os marcadores ADL183 e MCW36 foram inseridos sem alterar a ordem ou distância entre os demais marcadores. Isso pode ter acontecido pelo fato dos marcadores utilizados não serem completamente informativos, com menor número de meioses informativas, principalmente na região onde estes marcadores estão posicionados (Tabela 13).

A opção CHROMPIC do programa foi utilizada para verificar as fases de ligação de cada marcador ordenado no cromossomo para cada indivíduo. Sempre que foi constatada um dupla recombinação num intervalo de $50 \mathrm{cM}$, os genótipos foram 
conferidos e alguns erros foram encontrados. O mapa foi refeito com pequenas alterações nas distâncias, mas não no ordenamento.

O comprimento total do mapa obtido para a população em estudo (Embrapa) foi de 392 cM. Com uma distância média entre marcadores de 15,68 mas variando de 0,6 a 57,9 cM (distância média para os sexos).

Para a representação gráfica do mapa de ligação foi utilizado o software MapChart - versão 2,1 (Voorrips, 2002). Na Figura 16 são apresentados, para comparação, os mapas de ligação da população em estudo (Embrapa), mapa consenso (CN), Wageningen (W), East Lansing (E) e Compton (C) (http://poultry.mph.msu.edu/). Nestes mapas estão representados apenas os marcadores utilizados neste estudo.

Conforme pode ser observado na Figura 16, o mapa construído teve distâncias entre marcadores semelhantes as do mapa consenso e não houve alteração na ordem dos marcadores. Entretanto, metade (13) dos marcadores utilizados no presente estudo não está no mapa consenso, estes marcadores só foram mapeados nas populações mencionadas acima. Além disso, nenhuma das populações continha todos os marcadores utilizados neste estudo em um único mapa. Houveram pontos onde foram encontradas discrepâncias na ordem dos marcadores. A ordem do marcador MCW208 na população em estudo está invertida em relação ao marcador MCW10 quando comparado com a sua posição na população $W$, única população onde 0 marcador MCW208 foi mapeado. Foi então utilizada a opção FLIPS que executa trocas de ordenamento para cada loco, sendo considerada como ordem correta a de maior log10 da verossimilhança (log10 likelihood) e não houve alteração na ordem obtida anteriormente. Sugerindo que a ordem encontrada no presente estudo seja a correta devido ao número de meioses informativas obtidas. Entretanto, para confirmar esta inversão mais marcadores deverão ser genotipados para reduzir a distância entre os marcadores MCW208 e ADL188.

Os marcadores ADL234 e LEI68 estão mapeados na mesma posição nas três populações (W, E, C). Entretanto, no presente estudo foi obtida uma fração de recombinação de 0,06 entre estes marcadores com um LOD de 132,46 e uma distância calculada pelo programa utilizando a função de mapeamento de Kosambi de 5,9 cM. Como o marcador LEI 68 não está mapeado no mapa consenso e as famílias em que ele foi mapeado apresentam um menor número de meioses informativas. $\mathrm{Na}$ 
população W o número de meioses por marcador para todo genoma variou de $100 \mathrm{a}$ 900 com uma média de 400 em 10 famílias de irmãos completos com uma média de 46 F2 por família. Nas outras populações que geraram mapas de ligação, E (com 52 indivíduos de um cruzamento backcross) e C (com 56 indivíduos de um cruzamento backcross) o número de meioses informativas é ainda menor, variando de 20 a 56 (Schmid et al., 2000). Segundo Groenen et al. (1998) para se obter frações de recombinação para a construção de um mapa genético confiável é preciso um número elevado de meioses informativas, pois distâncias muito pequenas dificultam o ordenamento correto dos marcadores pela dificuldade de se obter recombinações.

No presente estudo o número de meioses informativas para cada marcador variou de 536 a 1.276, com média para os 26 marcadores de 963 (Tabela13).

Tabela13. Marcadores utilizados no mapa de ligação, número de alelos e número de meioses informativas

\begin{tabular}{lccc}
\hline Marcadores & Número de alelos & $\begin{array}{c}N^{0} \text { de meioses } \\
\text { informativas }\end{array}$ & $\begin{array}{c}N^{0} \text { de meioses informativas } \\
\text { (fase conhecida) }\end{array}$ \\
\hline MCW10 & 4 & 809 & 809 \\
MCW208 & 3 & 909 & 421 \\
ADL188 & 3 & 546 & 412 \\
ADL234 & 4 & 803 & 803 \\
LEI68 & 4 & 978 & 978 \\
MCW297 & 4 & 656 & 656 \\
LEI146 & 4 & 1267 & 891 \\
LEI174 & 3 & 536 & 536 \\
MCW18 & 4 & 1155 & 499 \\
ADL150 & 4 & 1248 & 542 \\
ADL319 & 2 & 726 & 444 \\
MCW58 & 3 & 1083 & 595 \\
LEI71 & 5 & 1276 & 770 \\
LEI138 & 2 & 774 & 398 \\
MCW68 & 5 & 995 & 689 \\
ADL20 & 5 & 1142 & 1142 \\
LEI160 & 3 & 1160 & 396 \\
ADL148 & 890 & 382 \\
MCW36 & 4 & 1081 & 263 \\
LEI169 & 3 & 1112 & 0 \\
LEI106 & 2 & 1008 & 620 \\
ADL183 & 3 & 1057 & 738 \\
LEI79 & 4 & 922 & 726 \\
MCW145 & 3 & 1002 & 666 \\
MCW20 & 3 & 1134 & 1134 \\
ROS25 & 4 & 792 & 697 \\
\hline & 4 & &
\end{tabular}


Optou-se por utilizar o mapa construído para a população em estudo nas análises de QTLs porque o número de animais utilizados, logo o número de meioses informativas, foi superior ao utilizado para a construção dos mapas das demais populações, o que aumenta a confiabilidade no mapa obtido. 
Embrapa

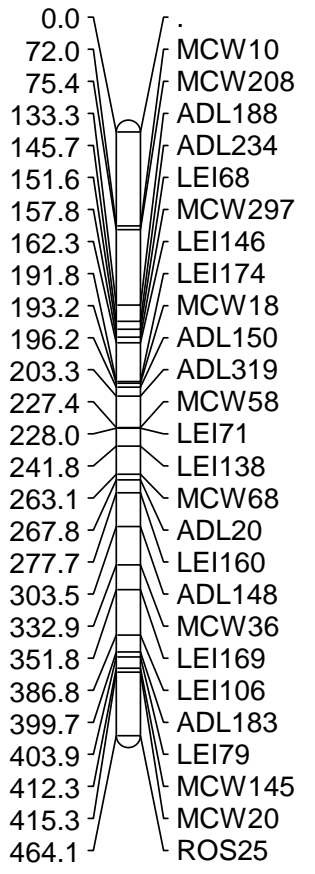

CN

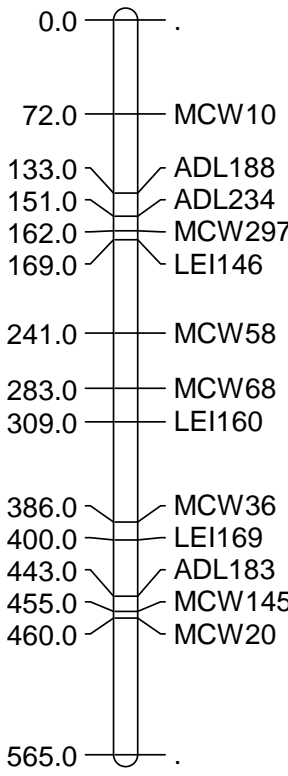

WAU

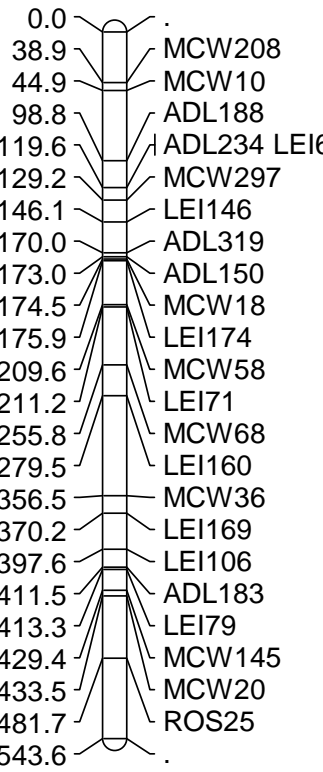

EL

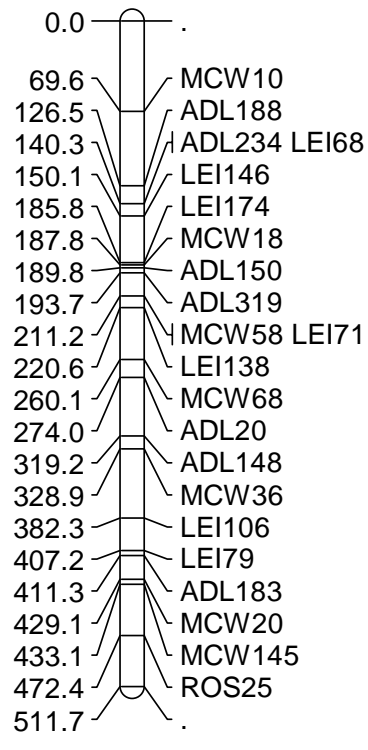

C

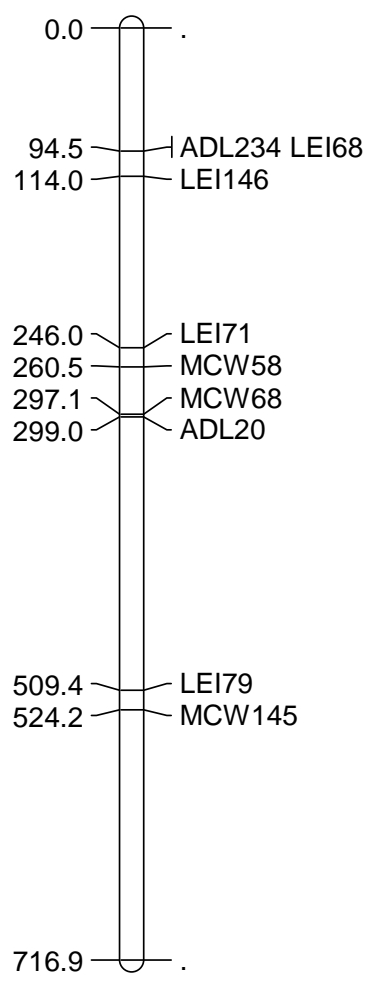

Figura 16 - Mapas de ligação em cM da população em estudo (Embrapa- utilizando função de Kosambi), mapa consenso $(C N)$, de Wageningen (W), de East Lansing (E) e de Compton (C) segundo posições encontradas no site http://poultry.mph.msu.edul. Nos mapas são apresentadas apenas as posições dos marcadores utilizados neste estudo, e as distâncias entre marcadores é dada como uma média entre sexos 


\subsection{Mapeamento de QTLs}

Foram realizadas análises exploratórias dos dados fenotípicos para identificar quais os efeitos fixos (família, sexo, incubação e interações) e covariáveis (PN, P35 e P42) fariam parte do modelo de análise de cada uma das características estudas.

Primeiramente foram eliminadas, em cada variável dentro de família, sexo e incubação observações que eram discrepantes. Optou-se por utilizar \pm 4 desvios-padrão pela grande variabilidade dos dados em estudo, esperada no cruzamento de linhagens divergentes. O número de observações, as médias, desvios-padrão, valor mínimo e máximo para cada variável, para os 653 animais F2, após a eliminação dos "outliers" são apresentados na Tabela 14.

Foi verificado que o efeito de incubações foi significativo para todas as características avaliadas (Tabela 15). Optou-se então por ajustar as características para o efeito de incubação e utilizar os resíduos da análise para o mapeamento de QTLs. Após o ajuste para o efeito de incubação, resíduos foram testados para os efeitos fixos de sexo, família e interação entre sexo e família, bem como para as covariáveis PN, P35 e P42, levando em consideração as particularidades de cada característica. Os resultados são apresentados nas Tabelas 16 e 17. Estes testes foram realizados para que na análise de mapeamento de QTL se utilizasse o modelo adequado para cada característica.

Como pode ser observado nas Tabelas 16 e 17, houve efeito significativo ( $P<$ 0,10) da interação sexo x família somente para as características PP, PA, PPeit e Pul. Os dados para estas características foram ajustados para o efeito da interação e os seus resíduos foram utilizados para o mapeamento de QTLs, já que o QTL EXPRESS, não permite o ajuste para efeitos de interação. 
Tabela 14. Número de observações $(\mathrm{N})$, médias, devios-padrão e valores máximos e mínimos para características de desempenho e caraça para os 653 animais F2 que foram utilizados no mapeamento de QTLS

\begin{tabular}{cccccc}
\hline Característica & $\mathrm{N}$ & Média & $\begin{array}{c}\text { Desvio- } \\
\text { Padrão }\end{array}$ & Mínimo & Máximo \\
\hline PN (g) & 659 & 44,514 & 4,258 & 15,6 & 55,5 \\
P35 (g) & 660 & 803,308 & 137,807 & 306 & 1341 \\
P41 (g) & 660 & 1022,880 & 184,777 & 407 & 1698 \\
P42 (g) & 660 & 987,762 & 182,484 & 402 & 1688 \\
C (g) & 660 & 643,197 & 128,064 & 234 & 1175 \\
PC (g) & 660 & 212,204 & 44,390 & 67 & 407 \\
PPeit (g) & 660 & 161,739 & 34,920 & 55 & 303 \\
R (g) & 660 & 187,044 & 38,394 & 75 & 350 \\
GA (g) & 660 & 16,247 & 7,819 & 0 & 55 \\
PA (g) & 660 & 82,209 & 14,581 & 31 & 140 \\
PP (g) & 659 & 40,105 & 8,781 & 16 & 74 \\
Fíg (g) & 659 & 26,627 & 5,191 & 15 & 49 \\
Cor (g) & 658 & 6,410 & 1,637 & 2 & 12 \\
Mo (g) & 659 & 24,296 & 4,491 & 13 & 39 \\
Pul (g) & 659 & 8,061 & 2,223 & 3 & 16 \\
CI (cm) & 659 & 153,789 & 14,915 & 111 & 204 \\
GP (g) & 655 & 221,942 & 66,046 & 4 & 418 \\
CR (g) & 660 & 602,121 & 135,529 & 218 & 1176 \\
CA & 651 & 2,855 & 0,741 & 1,35 & 7,551 \\
\hline
\end{tabular}

Peso ao nascer (PN), peso aos 35 (P35), 41 (P41) e 42 (P42) dias de idade; ganho de peso (GP), consumo de ração (CR) e conversão alimentar (CA) dos 35 aos 41 dias de idade, peso de pulmão (Pul), peso de fígado (Fig), peso de coração (Cor), peso de moela (Mo), comprimento do intestino (Cl), peso da carcaça (C), peso de peito (PPeit), peso de coxas $(P C)$, peso da carcaça residual (R), peso de asas (PA), peso da gordura abdominal (GA), peso de pés (PP). 
Tabela 15. Efeito de incubação

\begin{tabular}{ccc}
\hline Característica & Valores de F & Valores de P \\
\hline PN & 38,1071 & $<0,0001$ \\
P35 & 3,9033 & $<0,0001$ \\
P41 & 3,8935 & $<0,0001$ \\
P42 & 4,1789 & $<0,0001$ \\
C & 4,9183 & $<0,0001$ \\
PC & 3,3482 & $<0,0001$ \\
PPeit & 6,2042 & $<0,0001$ \\
R & 6,3905 & $<0,0001$ \\
GA & 8,7185 & $<0,0001$ \\
PA & 5,0450 & $<0,0001$ \\
PP & 2,2296 & 0,00386 \\
Fíg & 5,1314 & $<0,0001$ \\
Cor & 13,2539 & $<0,0001$ \\
Mo & 1,7020 & 0,0419 \\
Pul & 2,9195 & 0,000113 \\
Cl & 9,4168 & $<0,0001$ \\
GP & 6,6818 & $<0,0001$ \\
CR & 12,2653 & $<0,0001$ \\
CA & 3,7442 & $<0,0001$ \\
\hline
\end{tabular}

Peso ao nascer (PN), peso aos 35 (P35), 41 (P41) e 42 (P42) dias de idade; ganho de peso (GP), consumo de ração (CR) e conversão alimentar (CA) dos 35 aos 41 dias de idade, peso de pulmão (Pul), peso de fígado (Fig), peso de coração (Cor), peso de moela (Mo), comprimento do intestino (Cl), peso da carcaça (C), peso de peito (PPeit), peso de coxas $(P C)$, peso da carcaça residual $(R)$, peso de asas (PA), peso da gordura abdominal (GA), peso de pés (PP). 
Tabela 16. Efeitos fixos, das covariáveis e da interação sexo x família sobre as características de desempenho e $\mathrm{Cl}$

\begin{tabular}{|c|c|c|c|}
\hline Características & Efeitos & Valores de F & Valores de $\mathrm{P}$ \\
\hline \multirow{3}{*}{ PN } & sexo & 14,8745 & 0,000126 \\
\hline & família & 49,8410 & $<0,0001$ \\
\hline & sexo x família & 1,2737 & 0,267205 \\
\hline \multirow{4}{*}{ P35 } & PN & 0,1897 & 0,663296 \\
\hline & Sexo & 205,6006 & $<0,0001$ \\
\hline & Familia & 11,600 & $<0,0001$ \\
\hline & sexo x família & 0,8186 & 0,555659 \\
\hline \multirow{4}{*}{ P41 } & $\mathrm{PN}$ & 0,2066 & 0,649626 \\
\hline & Sexo & 241,7978 & $<0,0001$ \\
\hline & Familia & 10,6703 & $<0,0001$ \\
\hline & sexo $x$ família & 0,7366 & 0,620252 \\
\hline \multirow{4}{*}{ P42 } & $\mathrm{PN}$ & 0,1832 & 0,668739 \\
\hline & Sexo & 251,666 & $<0,0001$ \\
\hline & Familia & 11,8850 & $<0,0001$ \\
\hline & sexo x família & 0,6813 & 0,664842 \\
\hline \multirow{4}{*}{ GP } & P35 & 176,293 & $<0,0001$ \\
\hline & Sexo & 45,826 & $<0,0001$ \\
\hline & Família & 4,651 & 0,000122 \\
\hline & sexo $x$ família & 0,721 & 0,632 \\
\hline \multirow{4}{*}{$\mathrm{CR}$} & P35 & 160,695 & $<0,0001$ \\
\hline & Sexo & 32,677 & $<0,0001$ \\
\hline & Família & 5,026 & $<0,0001$ \\
\hline & sexo x família & 1,678 & 0.124 \\
\hline \multirow{4}{*}{ CA } & P35 & 10,498 & 0,0013 \\
\hline & Sexo & 6,796 & 0,0094 \\
\hline & Família & 3,507 & 0,00202 \\
\hline & sexo x família & 0,707 & 0,644 \\
\hline \multirow{4}{*}{$\mathrm{Cl}$} & P42 & 220,408 & $<0,0001$ \\
\hline & Sexo & 9,6166 & 0,00201 \\
\hline & Família & 2,851548 & 0,00951 \\
\hline & sexo x família & 0,369 & 0,898 \\
\hline
\end{tabular}

Peso aos 35 (P35), 41 (P41) e 42 (P42) dias de idade; ganho de peso (GP), consumo de ração (CR) e conversão alimentar (CA) dos 35 aos 41 dias de idade, comprimento do intestino (CI). 
Tabela 17. Efeitos fixos, da covariável e da interação sobre as características de carcaça

\begin{tabular}{|c|c|c|c|}
\hline Características* & Efeitos & Valores de F & Valores de P \\
\hline \multirow{4}{*}{ C } & Sexo & 12,8109 & 0,00037 \\
\hline & Família & 3,8088 & 0,000971 \\
\hline & sexo x família & 1,56626 & 0,154391 \\
\hline & P42 & 20373,05 & $<0,0001$ \\
\hline \multirow{4}{*}{ PC } & Sexo & 5,316 & 0,0214 \\
\hline & Família & 10,183 & $<0,0001$ \\
\hline & sexo x família & 0,6606 & 0,682 \\
\hline & P42 & 6037,187 & $<0,0001$ \\
\hline \multirow{4}{*}{ PPeit } & Sexo & 75,855 & $<0,0001$ \\
\hline & Família & 2,191 & 0,04218 \\
\hline & sexo x família & 2,103 & 0,0511 \\
\hline & P42 & 6350,032 & $<0,0001$ \\
\hline \multirow{4}{*}{$\mathrm{R}$} & Sexo & 4,205 & 0,0407 \\
\hline & Família & 2,624 & 0,0160 \\
\hline & sexo x família & 0,8977 & 0,4960 \\
\hline & $\mathrm{P} 42$ & 4787,487 & $<0,0001$ \\
\hline \multirow{4}{*}{ GA } & Sexo & 200,186 & $<0,0001$ \\
\hline & Família & 11,928 & $<0,0001$ \\
\hline & sexo x família & 0,6548 & 0,686315 \\
\hline & P42 & 695,963 & $<0,0001$ \\
\hline \multirow{4}{*}{ PA } & Sexo & 1277,458 & $<0,0001$ \\
\hline & Família & 76,1150 & $<0,0001$ \\
\hline & sexo x família & 4,1783 & 0,000393 \\
\hline & P42 & 4441,189 & $<0,0001$ \\
\hline \multirow{4}{*}{ PP } & Sexo & 593,545 & $<0,0001$ \\
\hline & Família & 35,539 & $<0,0001$ \\
\hline & sexo x família & 1,939 & 0,0724 \\
\hline & P42 & 2070,651 & $<0,0001$ \\
\hline \multirow{4}{*}{ Fíg } & Sexo & 19,835 & $<0,0001$ \\
\hline & Família & 3,911 & 0,000757 \\
\hline & sexo x família & 1,041 & 0,3977 \\
\hline & P42 & 706,131 & $<0,0001$ \\
\hline \multirow{4}{*}{ Cor } & Sexo & 16,547 & $<0,0001$ \\
\hline & Família & 4,361 & 0,00025 \\
\hline & sexo x família & 0,6806 & 0,665 \\
\hline & P42 & 287,667 & $<0,0001$ \\
\hline
\end{tabular}


Tabela 17. Efeitos fixos, da covariável e da interação sobre as características de carcaça

\begin{tabular}{cccc}
\hline Características* & Efeitos & Valores de $F$ & Valores de P \\
\hline \multirow{2}{*}{ Mo } & Sexo & 73,964 & $<0,0001$ \\
& Família & 4,4286 & 0,000212 \\
& sexo x família & 0,2416 & 0,9626 \\
PV42 & 258,0306 & $<0,0001$ \\
& Sexo & 6,660 & 0,01008 \\
& Família & 2,883 & 0,00884 \\
Pul & sexo x família & 1,979 & 0,0665 \\
& PV42 & 301,613 & $<0,0001$ \\
\hline
\end{tabular}

Peso da carcaça (C), peso de peito (PPeit), peso de coxas (PC), peso da carcaça residual (R), peso de asas (PA), peso da gordura abdominal (GA), peso de pés (PP), peso de pulmão (Pul), peso de fígado (Fig), peso de coração (Cor), peso de moela (Mo).

\subsubsection{Mapeamento de QTL - Análise de F2}

Esta análise assume que as linhagens TT e CC estão fixadas para alelos alternativos do QTL. Para cada característica as análises foram realizadas com e sem as covariáveis, sempre que significativas, na tentativa de se identificar genes ou grupo de genes que controlam peso vivo e as demais características, bem como genes que afetam as outras características de interesse independentemente do peso vivo.

Nas Tabelas 18 e 19 são apresentados apenas os QTLs que excederam ligação sugestiva. Detalhes dos efeitos aditivo e de dominância de cada QTL, juntamente com a porcentagem da variância fenotípica explicada pelo QTL, estão nas Tabelas 20 e 21.

Três QTLs foram detectados nesta análise para cada uma das seguintes características, P35, P41, P42 e C (Tabelas 18 e 19), isto sugere que distintos genes ou grupos de genes no cromossomo 1 da galinha estão envolvidos no crescimento global da ave. Alguns dos QTLs mapeados neste estudo não haviam sido registrados na literatura anteriormente, como QTL para PC, PPeit, PA, Cl, Mo, Fig, Pul e Cor.

Não foram detectados QTLs apenas para as características PN, GP e CA. Entretanto, quando P35 e P42 foram incluídos como covariáveis no modelo para características de desempenho e carcaça, respectivamente, apenas QTLs para PAaj, GAaj, PPaj e Claj foram identificados. Estes QTLs foram mapeados em posições diferentes dos QTLs localizados para estas características sem o ajuste. Isto sugere a existência de outros genes responsáveis pela variação fenotípica destas características, independentes dos genes que atuam no crescimento do indivíduo. Para todas as outras 
características pode-se sugerir duas hipóteses em relação aos genes que controlam o crescimento da ave: 1) as características são controladas pelos mesmos genes ou grupo de genes, 2) as características são controladas por diferentes genes mas que estão muito próximos. Estas hipóteses são fortalecidas pelos resultados obtidos por Melo et al. (2004), que avaliaram as correlações genéticas entre P42, PA, PC, PPeit, GA, GP e CR na população F2 desenvolvida pela Embrapa. As correlações genéticas variaram de 0,94 (entre P42 e PPeit e P42 e GP) a 0,53 (entre PA e GA).

Tabela 18. Posição do QTL no cromossomo 1 em relação ao primeiro marcador, marcadores flanqueadores e teste estatístico de QTLs que afetam as características de desempenho e que excederam ligação sugestiva no modelo de F2

\begin{tabular}{|c|c|c|c|}
\hline Característica & Posição (cM)² & Marcadores Flanqueadores & $\mathrm{F}^{1}$ \\
\hline P35 (g) & $\begin{array}{c}81 \\
184 \\
332\end{array}$ & $\begin{array}{l}\text { LEI68-MCW297 } \\
\text { LEI138-MCW68 } \\
\text { LEI79-MCW145 }\end{array}$ & $\begin{array}{c}10,41^{* *} \\
8,15^{\dagger} \\
7,15^{\dagger}\end{array}$ \\
\hline P41 (g) & $\begin{array}{c}81 \\
138 \\
332\end{array}$ & $\begin{array}{l}\text { LEI68-MCW297 } \\
\text { ADL319-MCW58 } \\
\text { LEI79-MCW145 }\end{array}$ & $\begin{array}{l}8,67^{\star} \\
7,46^{\dagger} \\
6,34^{\dagger}\end{array}$ \\
\hline P42 (g) & $\begin{array}{c}81 \\
138 \\
332\end{array}$ & $\begin{array}{l}\text { LEI68-MCW297 } \\
\text { ADL319-MCW58 } \\
\text { LEI79-MCW145 }\end{array}$ & $\begin{array}{l}8,54^{\star} \\
8,04^{\dagger} \\
7,15^{\dagger}\end{array}$ \\
\hline CR (g) & 125 & ADL150-ADL319 & $6,15^{\dagger}$ \\
\hline $\mathrm{Cl}(\mathrm{cm})$ & $\begin{array}{c}83 \\
339\end{array}$ & $\begin{array}{l}\text { LEI68-MCW297 } \\
\text { LEI79-MCW145 }\end{array}$ & $\begin{array}{l}11,12^{\star *} \\
12,92^{* *}\end{array}$ \\
\hline $\mathrm{Claj}^{3}(\mathrm{~cm})$ & $\begin{array}{c}84 \\
373\end{array}$ & $\begin{array}{l}\text { LEI68-MCW297 } \\
\text { MCW20-ROS25 }\end{array}$ & $\begin{array}{l}6,98^{\dagger} \\
9,80^{\star \star *}\end{array}$ \\
\hline
\end{tabular}

${ }^{1}$ Razão de $\mathrm{F}:{ }^{\dagger}$ Ligação sugestiva; * significativo a $\mathrm{P}<0,05$ no genoma, ** significativo a $\mathrm{P}<0,01$ no genoma.

${ }^{2}$ Posição do QTL em relação ao primeiro marcador no cromossomo 1 (MCW10 - 72 cM no mapa consenso).

${ }^{3}$ Análise de QTL incluiu o P42 como covariável no modelo.

Peso aos 35 (P35), 41 (P41) e 42 (P42) dias de idade; ganho de peso (GP), consumo de ração (CR) e conversão alimentar (CA) dos 35 aos 41 dias de idade, comprimento do intestino (Cl). 
Tabela 19. Posição do QTL no cromossomo 1 em relação ao primeiro marcador, marcadores flanqueadores e teste estatístico de QTLs que afetam as características de carcaça e que excederam ligação sugestiva no modelo de $\mathrm{F} 2$

\begin{tabular}{|c|c|c|c|}
\hline Característica & Posição (cM) ${ }^{2}$ & Marcadores Flanqueadores & $\mathrm{F}^{1}$ \\
\hline \multirow{3}{*}{$C(g)$} & 82 & LEI68-MCW297 & $8,65^{\star}$ \\
\hline & 139 & ADL319-MCW58 & $7,49^{\dagger}$ \\
\hline & 332 & LEI79-MCW145 & $5,61^{\dagger}$ \\
\hline$P C(g)$ & 97 & LEI146-LEI174 & $8,06^{\dagger}$ \\
\hline \multirow[t]{2}{*}{ PPeit (g) } & 138 & ADL319-MCW58 & $9,05^{\star}$ \\
\hline & 333 & LEI79-MCW145 & $7,29^{\dagger}$ \\
\hline \multirow[t]{2}{*}{$\mathrm{R}(\mathrm{g})$} & 93 & LEI146-LEI174 & $8,78^{*}$ \\
\hline & 200 & ADL20-LEI160 & $7,20^{\dagger}$ \\
\hline $\mathrm{GA}(\mathrm{g})$ & 196 & ADL20-LEI160 & $6,11^{\dagger}$ \\
\hline \multirow[t]{2}{*}{ GAaj $^{3}(g)$} & 94 & LEI146-LEI174 & $12,18^{\star *}$ \\
\hline & 251 & ADL148-MCW36 & $7,9^{\dagger}$ \\
\hline \multirow[t]{2}{*}{ PA (g) } & 84 & LEI68-MCW297 & $8,54^{*}$ \\
\hline & 334 & LEI79-MCW145 & $7,81^{\dagger}$ \\
\hline PAaj $^{3}(g)$ & 28 & MCW208-ADL188 & $5,23^{\dagger}$ \\
\hline \multirow[t]{2}{*}{$\mathrm{PP}(\mathrm{g})$} & 88 & MCW297-LEI146 & $10,62^{* *}$ \\
\hline & 332 & LEI79-MCW145 & $8,64^{*}$ \\
\hline $\mathrm{PPaj}^{3}(\mathrm{~g})$ & 194 & MCW68-ADL20 & $7,25^{\dagger}$ \\
\hline Mo (g) & 332 & LEI79-MCW145 & $6,72^{\dagger}$ \\
\hline Fig (g) & 86 & MCW297-LEI146 & $7,67^{\dagger}$ \\
\hline \multirow[t]{2}{*}{ Pul (g) } & 53 & MCW208-ADL188 & $8,20^{\dagger}$ \\
\hline & 88 & MCW297-LEI146 & $10,63^{* *}$ \\
\hline \multirow[t]{2}{*}{ Cor $(g)$} & 100 & LEI146-LEI174 & $11,33^{* *}$ \\
\hline & 332 & LEI79-MCW145 & $7,99^{\dagger}$ \\
\hline
\end{tabular}

${ }^{1}$ Razão de $\mathrm{F}:{ }^{\dagger}$ Ligação sugestiva; * significativo a $\mathrm{P}<0,05$ no genoma, ** significativo a $\mathrm{P}<0,01$ no genoma.

${ }^{2}$ Posição do QTL em relação ao primeiro marcador no cromossomo 1 (MCW10- 72 cM no mapa consenso).

${ }^{3}$ Análise de QTL incluiu o P42 como covariável no modelo.

Peso da carcaça (C), peso de peito (PPeit), peso de coxas (PC), peso da carcaça residual (R), peso de asas (PA), peso da gordura abdominal (GA), peso de pés (PP), peso de pulmão (Pul), peso de fígado (Fig), peso de coração (Cor), peso de moela (Mo). 
Tabela 20. Efeito aditivo e de dominância, seus erros-padrão (EP) e a proporção da variância fenotípica explicada pelo QTL para características de desempenho e comprimento de intestino

\begin{tabular}{lcccc}
\hline Característica & $\begin{array}{c}\text { Posição } \\
(\mathrm{cM})^{2}\end{array}$ & $\begin{array}{c}\text { Efeito Aditivo } \\
(\mathrm{EP})\end{array}$ & $\begin{array}{c}\text { Efeito de Dominância } \\
(\mathrm{EP})\end{array}$ & $\begin{array}{c}\text { Variância } \\
\text { Fenotípica (\%) }\end{array}$ \\
\hline P35 (g) & 81 & $29,307(6,657)$ & $7,405(9,464)$ & 2,94 \\
& 184 & $23,499(6,963)$ & $-2,258(11,503)$ & 1,51 \\
& 332 & $26,698(6,342)$ & $-7,348(9,510)$ & 2,56 \\
P41 (g) & 81 & $26,361(8,693)$ & $13,242(12,346)$ & 1,40 \\
& 138 & $31,125(9,486)$ & $-12,689(15,369)$ & 1,46 \\
& 332 & $30,705(8,185)$ & $-6,027(12,145)$ & 1,95 \\
P42 (g) & 81 & $24,568(8,482)$ & $15,194(12,046)$ & 1,35 \\
& 138 & $32,1424(9,256)$ & $-12,992(14,997)$ & 1,66 \\
& 332 & $30,905(7,987)$ & $-7,557(11,850)$ & 2,10 \\
CR (g) & 125 & $18,078(5,863)$ & $-14,869(8,314)$ & 1,63 \\
Cl (cm) & 83 & $3,044(0,719)$ & $-0,299(1,049)$ & 2,51 \\
& 339 & $3,488(0,680)$ & $0,064(1,004)$ & 3,78 \\
Claj $^{3}$ (cm) & 84 & $1,699(0,638)$ & $-0,954(0,918)$ & 0,98 \\
& 373 & $3,866(0,885)$ & $-1,894(1,964)$ & 2,80 \\
\hline
\end{tabular}

${ }^{2}$ Posição do QTL em relação ao primeiro marcador no cromossomo 1 (MCW10- 72 cM no mapa consenso).

${ }^{3}$ Análise de QTL incluiu o P42 como covariável no modelo.

Peso aos 35 (P35), 41 (P41) e 42 (P42) dias de idade; ganho de peso (GP), consumo de ração (CR) e conversão alimentar (CA) dos 35 aos 41 dias de idade, comprimento do intestino (Cl).

Alguns marcadores associados a QTLs nesta análise já foram anteriormente associados a QTLs em outras populações. O Marcador MCW58 foi associado a P41, P42, C e PPeit, e o marcador LEI79 foi associado a P35, P41, P42, C, PA, PPeit, PP, Mo e Cor. Em um cruzamento entre duas linhas fêmeas de frangos de corte, Van Kaam et al. (1999a,b), associaram o marcador MCW58 a peso vivo aos 48 dias de idade, e o marcador LEI 79 com percentagem de carcaça. Sewalen et al. (2002) mapeando QTLs em um cruzamento de linhagens de frangos de corte e postura associaram os marcadores LEI68 e LEI79 com peso vivo a 3 e 9 semanas de idade, respectivamente. No presente estudo, o marcador LEI68 foi associado a P35, P41, P42, C, PA e Cl.

Os marcadores LEI68, LEI79 e MCW58 no presente estudo foram associados a peso vivo e também ao peso de várias partes da carcaça sugerindo que próximo a estes marcadores existam genes ou grupos de genes ligados que controlam o crescimento global da ave. 
Tabela 21. Efeito aditivo e de dominância, seus erros-padrão (EP) e a proporção da variância fenotípica explicada pelo QTL para características de carcaça

\begin{tabular}{|c|c|c|c|c|}
\hline Característica & Posição (cM)² & Efeito Aditivo (EP) & $\begin{array}{c}\text { Efeito de } \\
\text { Dominância (EP) }\end{array}$ & $\begin{array}{c}\text { Variância } \\
\text { Fenotípica (\%) }\end{array}$ \\
\hline \multirow[t]{3}{*}{ C (g) } & 82 & $16,131(6,054)$ & $12,519(8,606)$ & 1,21 \\
\hline & 139 & $23,549(6,546)$ & $-8,861(10,606)$ & 1,79 \\
\hline & 332 & $19,778(5,648)$ & $-5,030(8,379)$ & 1,68 \\
\hline PC (g) & 97 & $8,584(2,210)$ & $3,286(3,473)$ & 2,22 \\
\hline \multirow[t]{2}{*}{ PPeit (g) } & 138 & $7,541(1,752)$ & $-3,348(2,838)$ & 2,73 \\
\hline & 333 & $5,117(1,610)$ & $-2,187(2,408)$ & 1,39 \\
\hline \multirow[t]{2}{*}{$\mathrm{R}(\mathrm{g})$} & 93 & $6,874(1,791)$ & $3,378(2,617)$ & 2,30 \\
\hline & 200 & $4,851(1,706)$ & $-5,125(2,666)$ & 1,45 \\
\hline GA (g) & 196 & $0,978(0,352)$ & $-1,271(0,524)$ & 1,62 \\
\hline \multirow[t]{2}{*}{ GAaj $^{3}(\mathrm{~g})$} & 94 & $-1,344(0,277)$ & $0,318(0,409)$ & 3,44 \\
\hline & 251 & $0,658(0,324)$ & $-0,972(0,572)$ & 0,81 \\
\hline \multirow[t]{2}{*}{ PA (g) } & 84 & $2,509(0,642)$ & $0,941(0,932)$ & 2,28 \\
\hline & 334 & $2,348(0,626)$ & $-0,513(0,943)$ & 1,95 \\
\hline PAaj $^{3}(g)$ & 28 & $0,603(0,357)$ & $-2,353(0,825)$ & 1,35 \\
\hline \multirow[t]{2}{*}{$P P(g)$} & 88 & $1,517(0,346)$ & $0,386(0,492)$ & 2,83 \\
\hline & 332 & $1,216(0,338)$ & $-0,177(0,502)$ & 1,74 \\
\hline $\mathrm{PPaj}^{3}(\mathrm{~g})$ & 194 & $-0,532(0,161)$ & $0,546(0,241)$ & 1,98 \\
\hline Mo (g) & 332 & $0,747(0,206)$ & $-0,191(0,306)$ & 1,8 \\
\hline Fig (g) & 86 & $0,901(0,251)$ & $0,542(0,357)$ & 2,10 \\
\hline \multirow[t]{2}{*}{ Pul (g) } & 53 & $-0,401(0,212)$ & $-1,036(0,365)$ & 1,67 \\
\hline & 88 & $0,723(0,168)$ & $0,611(0,201)$ & 4,04 \\
\hline \multirow[t]{2}{*}{ Cor (g) } & 100 & $0,390(0,084)$ & $0,020(0,138)$ & 3,09 \\
\hline & 332 & $0,208(0,072)$ & $-0,097(0,107)$ & 1,13 \\
\hline
\end{tabular}

${ }^{2}$ Posição do QTL em relação ao primeiro marcador no cromossomo 1 (MCW10- 72 cM no mapa consenso).

${ }^{3}$ Análise de QTL incluiu o P42 como covariável no modelo.

Peso da carcaça (C), peso de peito (PPeit), peso de coxas (PC), peso da carcaça residual (R), peso de asas (PA), peso da gordura abdominal (GA), peso de pés (PP), peso de pulmão (Pul), peso de fígado (Fig), peso de coração (Cor), peso de moela (Mo). 
Jennen et al. (2004) associaram o marcador LEI174 com QTLs para peso da gordura abdominal a 10 semanas de idade. Tatsuda \& Fujinaka (2001) encontraram um QTL ligado ao marcador LEI174 afetando peso corporal as 13 e 16 semanas de idade em um cruzamento entre linhagens de frangos de corte. No presente estudo, este marcador foi associado com o peso da gordura abdominal utilizando P42 como covariável, mas também foi associado com QTLs para PC, PA, R e Cor (Tabela 19), sugerindo que nesta região existem genes envolvidos na deposição de gordura e crescimento.

Três regiões foram associadas à deposição de gordura abdominal (Tabela 19) uma entre os marcadores ADL20 e LEI160, associada com GA e outras duas entre LEI146-LEI174 e ADL148-MCW36 que foram associadas com GAaj. Ikeobi et al. (2002) detectaram QTL para peso da gordura abdominal utilizando peso corporal como covariável entre os marcadores ADL188 e LEI68. Estes marcadores foram incluídos em nosso estudo, porém não foram associados a peso da gordura abdominal, mas estão próximos aos marcadores LEI146 e LEI174, associados com GAaj. Estes resultados indicam ser esta uma região candidata para estudos futuros, pois a gordura abdominal é uma das características de grande interesse para a indústria avícola. Como a gordura é positivamente correlacionada com o peso vivo (Tabela 11), se houver nesta região genes que controlam a deposição de gordura independentemente do crescimento pode ser uma região interessante para estudos de genes candidatos por posição.

A proporção da variância fenotípica total na F2 atribuída a um QTL neste estudo variou de 0,81 a 4,04 (Tabelas 20 e 21). Os efeitos aditivos de cada QTL foram positivos para praticamente todas as características, com exceção dos QTLs para GAaj, PPaj e Pul (Tabelas 21 e 22). Este efeito negativo indica que os alelos provenientes da linhagem $C C$ reduzem os valores fenotípicos destas características. Os QTLs detectados para as características PAaj, R, GA, GAaj, PPaj e Pul apresentaram efeito de dominância significativo com efeito negativo (Tabela 21). Estes efeitos sugerem que os indivíduos que receberam um alelo da linhagem de corte TT e outro da linhagem de postura CC tiveram uma menor média para essas características do que a media dos homozigotos para o QTL.

Interações entre QTL e sexo não foram significativas para nenhuma das características estudadas, sugerindo não haver diferentes QTLs segregando para os sexos. Também não houve evidência de efeito de "impriting" afetando as características 
avaliadas para o cromossomo 1. Entretanto, apesar de ter sido possível mapear vários QTLs utilizando a análise de F2, a pressuposição do modelo foi violada para várias características. Quando foi testada a interação entre QTL e família, esta foi significativa para P35, P41, P42, C, PPeito, GAaj, R, CR, Cl e Cor, com valores de P variando de 0,04 a 0,005. Logo, as linhagens TT e CC não estão fixadas para os QTLs mapeados para estas características. Ao se violar esta pressuposição a análise de F2 pode não ser o melhor modelo de análise para a população em estudo. O presente trabalho é o pioneiro em mostrar a significância deste tipo de interação em aves, isso pode ser devido ao tamanho das famílias de F2 utilizado (em torno de 95 animais), pois segundo Knott et al. (1998) para se testar a interação QTL e família necessita-se de famílias de F2 de tamanho razoável. Talvez por isso Sewalen et al. (2002) e Ikeobi et al. (2002) não encontraram interação entre QTL x família, pois utilizaram famílias de F2 com 14 indivíduos em média.

Segundo De Koning et al. (1999), o modelo de análise F2 ("line-cross") é muito poderoso para detectar QTLs quando os alelos dos QTLs estão fixados nas linhagens. Mas seu poder pode ser reduzido a zero se as freqüências dos alelos compartilhados do QTL forem iguais nas linhagens. Neste caso, somente o modelo de meio-irmãos tem algum poder de detectar QTLs nesse caso. Entretanto, quando o número de alelos compartilhados do QTL nas linhagens é moderado, espera-se que o modelo de análise F2 tenha um poder de detectar QTLs considerável (Alfonso \& Haley, 1998).

$\mathrm{Na}$ tentativa de entender melhor o controle genético das características avaliadas no presente estudo e mapear outros QTLs importantes, optou-se por realizar também a análise de meio-irmãos paternos (paternal half-sibs), uma vez que a estrutura da população permite utilizar os dois modelos genéticos. Segundo De Koning et al. (1999, 2001), a combinação dos dois tipos de análise proporciona uma maior compreensão do número de QTLs influênciando a característica de interresse.

\subsubsection{Mapeamento de QTLs - Análise de Meio-irmãos Paternos}

Os QTLs mapeados utilizando o modelo de meio-irmãos são apresentados nas Tabelas 22 e 23, respectivamente, para características de desempenho e carcaça. A análise de meio-irmãos detectou QTLs para GPaj, CAaj e para Mo.aj, Fig.aj, Pul.aj e Cor.aj. Esses QTLs não tinham sido mapeados na análise de F2. Estes resultados 
confirmam as afirmações de De Koning et al. (2001), de que para estes QTLs a violação da pressuposição de alelos fixados nas linhagens foi tão severa que a abordagem de meio-irmãos foi superior ao modelo F2 para a detecção de QTLs.

Os QTLs detectados na análise de meio-irmãos foram mapeados em diferentes posições dos QTLs detectados na análise de F2. De Koning et al. (1999) afirmam que estas diferenças podem ser explicadas pela natureza do efeito do QTL e pelas pressuposições assumidas em cada modelo. Geralmente, os resultados obtidos mostram pouca correspondência entre os achados no modelo de F2 e de meio-irmãos (De Koning et al. 2001). A análise de F2 é mais apropriada para detectar QTLs que explicam as diferenças fenotípicas entre linhagens, enquanto a análise de meio-irmãos é mais apropriada para detectar QTLs que explicam diferenças dentro de famílias. Em alguns casos, os QTLs identificados por estas duas análises podem ser realmente QTLs diferentes. De Koning et al. (1999) afirmaram que a utilização dos dois modelos proporciona um maior conhecimento do número de QTLs que afetam a característica e o seu modo de ação.

Alguns QTLs mapeados para algumas características na análise de F2 podem não ter sido detectados na análise de meio-irmãos pela natureza dominante do QTL. Segundo De Koning et al. (1999), o efeito de dominância contribui pouco para o efeito de substituição do alelo que é estimado na análise de meio-irmãos. Isso pode ter ocorrido no presente estudo para os QTLs que afetam PAaj a 28 cM, GA a 251cM e PPaj a 194 cM mapeados na análise de F2 que não foram mapeados na análise de meio-irmãos. Esses QTLs apresentaram efeito de dominância (Tabela 21), podendo ser esta a justificativa de não terem sido detectados na análise de meio-irmãos.

A única característica para a qual não foi mapeado QTL foi PN. Na análise de F2 também não foi detectado QTL para PN. Isso sugere que não existem genes no cromossomo 1 que controlem o desenvolvimento dos pintinhos ao redor do nascimento, ou podem existir genes, mas, com efeito pequeno sobre o peso ao nascer e que não seja possível detectar com o tamanho das populações normalmente utilizadas. Pois não há relatos na literatura de QTLs para peso ao nascer, apenas Kerje et al. (2003) encontraram QTL para peso corporal aos 8 dias de idade entre os marcadores MCW10 e ADL19 num cruzamento entre uma linhagem White Leghorn e uma raça selvagem (Red Jungle Fowl). 
Tabela 22. Posição do QTL no cromossomo 1 em relação ao primeiro marcador, marcadores flanqueadores, teste estatístico de QTLs que afetam as características de desempenho e comprimento de intestino $(\mathrm{Cl})$ que excederam ligação sugestiva no modelo de meio-irmãos e porcentagem da variância fenotípica explicada pelos QTLs.

\begin{tabular}{|c|c|c|c|c|}
\hline Característica & $\begin{array}{l}\text { Posição } \\
(\mathrm{cM})^{2}\end{array}$ & $\begin{array}{c}\text { Marcadores } \\
\text { flanqueadores }\end{array}$ & $\mathrm{F}^{1}$ & Variância fenotípica (\%) \\
\hline P35 (g) & $\begin{array}{l}109 \\
294\end{array}$ & $\begin{array}{l}\text { LEI146-LEI174 } \\
\text { LEI169-LEI106 }\end{array}$ & $\begin{array}{c}11,84^{\star \star} \\
8,1^{\star \star}\end{array}$ & $\begin{array}{l}5,07 \\
1,51\end{array}$ \\
\hline P41 (g) & $\begin{array}{c}75 \\
125\end{array}$ & $\begin{array}{l}\text { ADL234-LEI68 } \\
\text { ADL150-ADL319 }\end{array}$ & $\begin{array}{c}7,12^{*} \\
11,27^{\star *}\end{array}$ & $\begin{array}{l}0,78 \\
3,56\end{array}$ \\
\hline P42 (g) & $\begin{array}{c}76 \\
125\end{array}$ & $\begin{array}{l}\text { ADL234-LEI68 } \\
\text { ADL150-ADL319 }\end{array}$ & $\begin{array}{l}7,38^{\star *} \\
11,75^{\star *}\end{array}$ & $\begin{array}{l}0,91 \\
3,51\end{array}$ \\
\hline GP (g) & 141 & ADL319-MCW58 & $5,1^{\dagger}$ & 1,93 \\
\hline $\mathrm{GPaj}^{3}(\mathrm{~g})$ & 283 & LEI169-LEI106 & $4,58^{\dagger}$ & 1,69 \\
\hline CR (g) & 123 & MCW18-ADL150 & $6,95^{\star}$ & 2,78 \\
\hline CA & 296 & LEI169-LEI106 & $4,7^{\dagger}$ & 1,73 \\
\hline CAaj $^{3}$ & 295 & LEI169-LEI106 & $5,5^{\dagger}$ & 2,10 \\
\hline $\mathrm{Cl}(\mathrm{cm})$ & $\begin{array}{l}125 \\
366\end{array}$ & $\begin{array}{l}\text { ADL150-ADL319 } \\
\text { MCW20-ROS25 }\end{array}$ & $\begin{array}{l}8,8^{\star \star} \\
7,6^{\star \star}\end{array}$ & $\begin{array}{c}4,0 \\
2,44\end{array}$ \\
\hline $\mathrm{Claj}^{3}(\mathrm{~cm})$ & 369 & MCW20-ROS25 & $4,39^{\dagger}$ & 1,60 \\
\hline
\end{tabular}

${ }^{1}$ Razão de $\mathrm{F}:{ }^{\dagger}$ Ligação sugestiva; * significativo a $\mathrm{P}<0,05$ no genoma, ** significativo a $\mathrm{P}<0,01$ no genoma.

${ }^{2}$ Posição do QTL em relação ao primeiro marcador no cromossomo 1 (MCW10- 72 cM no mapa consenso).

${ }^{3}$ Análise de QTL incluiu o P35 como covariável no modelo, para Cl foi utilizado o P42 como covariável. Peso aos 35 (P35), 41 (P41) e 42 (P42) dias de idade; ganho de peso (GP), consumo de ração (CR) e conversão alimentar (CA) dos 35 aos 41 dias de idade, comprimento do intestino $(\mathrm{Cl})$. 
Tabela 23. Posição do QTL no cromossomo 1 em relação ao primeiro marcador, marcadores flanqueadores, teste estatístico de QTLs que afetam as características de carcaça que excederam ligação sugestiva no modelo de meio-irmãos e porcentagem da variância fenotípica explicada pelos QTLs.

\begin{tabular}{|c|c|c|c|c|}
\hline Característica & Posição (cM) ${ }^{2}$ & $\begin{array}{c}\text { Marcadores } \\
\text { flanqueadores }\end{array}$ & $\mathrm{F}^{1}$ & $\begin{array}{c}\text { Variância } \\
\text { fenotípica (\%) }\end{array}$ \\
\hline C (g) & $\begin{array}{l}137 \\
170\end{array}$ & $\begin{array}{l}\text { ADL319-MCW58 } \\
\text { LEI138-MCW68 }\end{array}$ & $\begin{array}{c}10,87^{* *} \\
7,01^{*}\end{array}$ & $\begin{array}{l}4,60 \\
0,93\end{array}$ \\
\hline PA (g) & $\begin{array}{l}124 \\
365\end{array}$ & $\begin{array}{l}\text { MCW18-ADL150 } \\
\text { MCW20-ROS25 }\end{array}$ & $\begin{array}{l}8,31^{\star *} \\
6,57^{*}\end{array}$ & $\begin{array}{l}3,51 \\
1,78\end{array}$ \\
\hline PAaj $^{3}(g)$ & $\begin{array}{l}171 \\
372\end{array}$ & $\begin{array}{l}\text { LEI138-MCW68 } \\
\text { MCW20-ROS25 }\end{array}$ & $\begin{array}{l}5,47^{\dagger} \\
7,83^{\star *}\end{array}$ & $\begin{array}{l}0,94 \\
2,72\end{array}$ \\
\hline$P C(g)$ & $\begin{array}{l}124 \\
291\end{array}$ & $\begin{array}{l}\text { MCW18-ADL150 } \\
\text { LEI169-LEI106 }\end{array}$ & $\begin{array}{c}10,06^{\star *} \\
6,75^{\star}\end{array}$ & $\begin{array}{l}4,17 \\
1,11\end{array}$ \\
\hline PPeit (g) & $\begin{array}{l}126 \\
172\end{array}$ & $\begin{array}{l}\text { ADL150-ADL319 } \\
\text { LEI138-MCW68 }\end{array}$ & $\begin{array}{l}10,52^{\star *} \\
6,97^{\star}\end{array}$ & $\begin{array}{l}4,36 \\
1,11\end{array}$ \\
\hline $\mathrm{R}(\mathrm{g})$ & $\begin{array}{c}74 \\
124\end{array}$ & $\begin{array}{l}\text { ADL234-LEI68 } \\
\text { MCW18-ADL150 }\end{array}$ & $\begin{array}{c}7,27^{*} \\
10,21^{\star *}\end{array}$ & $\begin{array}{l}1,51 \\
3,31\end{array}$ \\
\hline GA (g) & 175 & LEI138-MCW68 & $4,23^{\dagger}$ & 1,52 \\
\hline GAaj $^{3}(\mathrm{~g})$ & 388 & MCW20-ROS25 & $5,31^{\dagger}$ & 2,03 \\
\hline$P P(g)$ & $\begin{array}{l}124 \\
370\end{array}$ & $\begin{array}{l}\text { MCW18-ADL150 } \\
\text { MCW20-ROS25 }\end{array}$ & $\begin{array}{l}8,75^{\star \star} \\
6,67^{\star}\end{array}$ & $\begin{array}{l}3,78 \\
1,63\end{array}$ \\
\hline $\mathrm{PPaj}^{3}(\mathrm{~g})$ & 380 & MCW20-ROS25 & $5,32^{\dagger}$ & 2,03 \\
\hline Mo (g) & $\begin{array}{c}85 \\
370\end{array}$ & $\begin{array}{l}\text { MCW297-LEI146 } \\
\text { MCW20-ROS25 }\end{array}$ & $\begin{array}{l}5,61^{\dagger} \\
7,62^{\star \star}\end{array}$ & $\begin{array}{l}1,20 \\
3,11\end{array}$ \\
\hline Mo.aj ${ }^{3}(g)$ & $\begin{array}{l}165 \\
373\end{array}$ & $\begin{array}{l}\text { LEI71-LEI138 } \\
\text { MCW20-ROS25 }\end{array}$ & $\begin{array}{l}4,9^{\dagger} \\
6,6^{*}\end{array}$ & $\begin{array}{l}1,02 \\
2,38\end{array}$ \\
\hline Fig (g) & $\begin{array}{c}89 \\
128\end{array}$ & $\begin{array}{l}\text { MCW297-LEI146 } \\
\text { ADL150-ADL319 }\end{array}$ & $\begin{array}{c}7,2^{\star} \\
11,75^{\star \star}\end{array}$ & $\begin{array}{c}0,75 \\
3,0\end{array}$ \\
\hline Fig.aj ${ }^{3}(g)$ & 170 & LEI138-MCW68 & $6,44^{*}$ & 2,17 \\
\hline Pul (g) & $\begin{array}{c}68 \\
100\end{array}$ & $\begin{array}{l}\text { ADL188-ADL234 } \\
\text { LEI146-LEI174 }\end{array}$ & $\begin{array}{l}7,78^{\star *} \\
11,94^{\star *}\end{array}$ & $\begin{array}{l}1,15 \\
5,26\end{array}$ \\
\hline Pul.aj ${ }^{3}(g)$ & 93 & LEI146-LEI174 & $4,86^{\dagger}$ & 1,82 \\
\hline Cor (g) & 107 & LEI146-LEI174 & $10,31^{* *}$ & 4,28 \\
\hline Cor.aj ${ }^{3}(g)$ & 101 & LEI146-LEI174 & $4,6^{\dagger}$ & 1,69 \\
\hline
\end{tabular}

${ }^{1}$ Posição do QTL em relação ao primeiro marcador no cromossomo 1 (MCW10- 72 cM no mapa consenso).

${ }^{2}$ Razão de F: ${ }^{\dagger}$ Ligação sugestiva; * significativo a $\mathrm{P}<0,05$ no genoma, ** significativo a $\mathrm{P}<0,01$ no genoma.

${ }^{3}$ Análise de QTL incluiu o P42 como covariável no modelo. 
A análise de meio-irmãos foi realizada primeiramente utilizando as três famílias de meio-irmãos paternos em conjunto. Segundo De Koning et al. (2001), a análise de meio-irmãos é realizada dentro de cada família, entretanto, os resíduos são estabelecidos entre famílias para cálculo do teste estatístico (estatística F) e as evidências de um QTL são apresentadas de uma forma conjunta para todas as famílias. Nesta análise conjunta foi verificado que para várias características apenas uma família estava segregando para o QTL. Para outras características como, por exemplo, P35, P42 e GA as famílias estavam segregando para diferentes QTLs. Optou-se então por realizar a análise dentro de cada família individualmente, mesmo correndo-se o risco de perda do poder de detectar QTLs pela redução do número de indivíduos utilizados na análise (família 1 = 186 F2, família 2= 289 F2 e família 3=174 F2). Os efeitos de substituição do alelo dos QTLs foram apresentados apenas para as famílias individualmente (Tabelas 24 e 25). Os efeitos de substituição do alelo dos QTLs mapeados variaram de $-83,336$ a 130,864, o que indica que a presença de um alelo do QTL pode aumentar ou reduzir a média da característica. Por exemplo, o QTL para P42, mapeado a $124 \mathrm{cM}$ na família 1, tem um efeito que representa um aumento de $130 \mathrm{~g}$ na média da família para esta característica na presença de um alelo.

Nas análises de meio-irmãos conjunta e individual as posições dos QTLs mapeados são muito semelhantes para a maioria das características. Pequenas diferenças na posição, segundo De Koning et al. (1999), podem ser parcialmente explicadas pelos níveis de informação dos marcadores nas diferentes famílias.

Outro fato que pode ser observado quando foi realizada a análise individual de cada família é o que ocorreu, por exemplo, para GAaj (Tabela 25). Foram mapeados QTLs em diferentes posições para cada uma das famílias. Esses QTLs têm também efeito de substituição do alelo de sinal contrário em cada família (família 1: -1,448 g; família 2: -2,144 g e família 3: 2,654 g) o que na análise conjunta podem originar desvios na posição mais provável do QTL.

Na Figura 17 é apresentado o resultado do mapeamento de QTL em cada uma das famílias para P42. Este é outro exemplo em que diferentes QTLs estão segregando nas famílias. 
Tabela 24. Posições cromossômicas, estimativas do efeito de substituição do alelo, porcentagem da variância fenotípica explicada pelo QTL (V.F.) e intervalo de confiança (I.C.), dos QTLs para as características de desempenho e $\mathrm{Cl}$ que excederam o nível de ligação sugestiva em cada família de meio-irmãos Nos subtítulos (em itálico) são apresentadas as posições e a significância dos QTLs mapeados nas análises das famílias de meio-irmãos em conjunto

\begin{tabular}{|c|c|c|c|c|c|c|}
\hline Família & $\begin{array}{c}\text { Posição }^{2} \\
\text { (cM) }\end{array}$ & $\begin{array}{c}\text { Marcadores } \\
\text { flanqueadores }\end{array}$ & $\mathrm{F}^{1}$ & $\begin{array}{c}\text { Efeito de } \\
\text { substituição (EP) }\end{array}$ & $\begin{array}{l}\text { V. F. } \\
(\%)\end{array}$ & $\begin{array}{l}\text { I.C. } \\
\text { (cM) }\end{array}$ \\
\hline \multicolumn{7}{|c|}{$P 35-109^{* *}$ e $294^{* *} c M$} \\
\hline \multirow[t]{2}{*}{1} & 80 & LEI68-MCW297 & $6,89^{\dagger}$ & $41,24(15,71)$ & 3,24 & \\
\hline & 126 & ADL150-ADL319 & $24,18^{\star \star}$ & $83,42(16,98)$ & 11,62 & $72-131$ \\
\hline 2 & 73 & ADL188-ADL234 & $7,49^{\dagger}$ & $-36,88(13,48)$ & 2,2 & $16-271$ \\
\hline 3 & 292 & LEI169-LEI106 & $11,9^{\dagger}$ & $-83,34(24,16)$ & 6,13 & $22-364$ \\
\hline \multicolumn{7}{|c|}{$P 41-75^{\star \star}$ e $125^{\star \star} c M$} \\
\hline 1 & 124 & MCW18-ADL150 & $37,45^{\star *}$ & $130,86(21,39)$ & 17,07 & $107-138$ \\
\hline 2 & 73 & & $6,2^{\mathrm{NS}}$ & & & \\
\hline 3 & 296 & LEI169-LEI106 & $6,46^{\dagger}$ & $-76,68(30,17)$ & 3,17 & $4-371$ \\
\hline \multicolumn{7}{|c|}{$P 42-76^{\star \star}$ e $125^{\star \star} c M$} \\
\hline 1 & 124 & MCW18-ADL150 & $38,78^{* *}$ & $130,31(20,93)$ & 17,6 & $105-137$ \\
\hline 2 & 74 & & $6,36^{\mathrm{NS}}$ & & & - \\
\hline 3 & 292 & LEI169-LEI106 & $7,57^{\dagger}$ & $-82,12(29,85)$ & 3,78 & $3-376$ \\
\hline \multicolumn{7}{|c|}{$G P-141^{\dagger} c M$} \\
\hline 1 & 141 & ADL319-MCW58 & $14,22^{*}$ & $37,48(9,94)$ & 6,95 & $124-319$ \\
\hline 2 & 274 & & $0,99^{\mathrm{N} S}$ & , & - & - \\
\hline 3 & 332 & LEI79-MCW145 & $1,51^{\mathrm{NS}}$ & - & - & - \\
\hline \multicolumn{7}{|c|}{$G P a j^{3}-283^{\dagger} c M$} \\
\hline 1 & 301 & LEI169-LEI106 & $7,30^{\dagger}$ & $-24,16(8,94)$ & 3,54 & $70-336$ \\
\hline 2 & 264 & 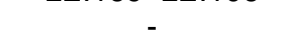 & $2,04^{\text {NS }}$ & - & - & - \\
\hline 3 & 280 & - & $4,80^{\mathrm{NS}}$ & - & - & - \\
\hline \multicolumn{7}{|c|}{$C R-123^{*} C M$} \\
\hline 1 & 137 & ADL319-MCW58 & $22,47^{\star \star}$ & $82,43(17,39)$ & 10,82 & $111-150$ \\
\hline 2 & 171 & - & $2,18^{\mathrm{NS}}$ & - & - & - \\
\hline 3 & 0 & - & $3,41^{\mathrm{NS}}$ & - & - & - \\
\hline \multicolumn{7}{|c|}{$C A-295^{\dagger} \mathrm{cM}$} \\
\hline 1 & 309 & LEI106-ADL183 & $7,74^{\dagger}$ & $0,39(0,14)$ & 3,67 & $51-383$ \\
\hline 2 & 165 & & $1,07^{\text {NS }}$ & - & 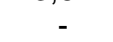 & - \\
\hline 3 & 283 & & $5,66^{\mathrm{NS}}$ & & - & - \\
\hline \multicolumn{7}{|c|}{ CAaj $^{3}-295^{\dagger} \mathrm{CM}$} \\
\hline 1 & 317 & LEI106-ADL183 & $8,27^{\dagger}$ & $0,38(0,13)$ & 3,98 & $65-333$ \\
\hline 2 & 169 & - & $2,17^{\mathrm{NS}}$ & - & - & - \\
\hline 3 & 284 & - & $5,68^{\mathrm{NS}}$ & - & - & - \\
\hline \multicolumn{7}{|c|}{$C l-125^{\star \star}$ e $366^{\star *} c M$} \\
\hline 1 & 127 & ADL150-ADL319 & $32,69 * *$ & $\begin{array}{l}9,79(1,71) \\
337(1,55)\end{array}$ & $\begin{array}{c}15,18 \\
104\end{array}$ & $110-344$ \\
\hline 2 & $\begin{array}{l}332 \\
86\end{array}$ & $\begin{array}{c}\text { LEI/Y-IVICVILS } \\
-\end{array}$ & $5,8^{\mathrm{NS}}$ & J, & - & - \\
\hline \multirow{2}{*}{\multicolumn{7}{|c|}{$\mathrm{Claj}^{3}-369^{\dagger} \mathrm{cM}$}} \\
\hline & & & & & & \\
\hline 1 & 140 & ADL319-MCW58 & $9,79^{\dagger}$ & $5,75(1,84)$ & 4,76 & $124-392$ \\
\hline 2 & 340 & - & $3,23^{\mathrm{NS}}$ & & & - \\
\hline 3 & 0 & MCW10-MCW208 & $10,1^{\dagger}$ & $-5,70(1,79)$ & 5,20 & $0-379$ \\
\hline
\end{tabular}


Tabela 25. Posições cromossômicas, estimativas do efeito de substituição do alelo, porcentagem da variância fenotípica explicada pelo QTL (V.F.) e intervalo de confiança (I.C.), dos QTLs para as características de carcaça que excederam o nível de ligação sugestiva em cada família de meio-irmãos. Nos subtítulos (em itálico) são apresentadas as posições e a significância dos QTLs mapeados nas análises das famílias de meio-irmãos em conjunto

\begin{tabular}{|c|c|c|c|c|c|c|}
\hline Famila & Posição² & $\begin{array}{c}\text { Marcadores } \\
\text { flanqueadores }\end{array}$ & $\mathrm{F}^{1}$ & $\begin{array}{c}\text { Efeito de } \\
\text { substituição (EP) }\end{array}$ & V. F. (\%) & I.C. \\
\hline \multicolumn{7}{|c|}{$C-137^{* *}$ e $170^{*} c M$} \\
\hline 1 & 124 & MCW18-ADL150 & $35,71^{\star *}$ & $88,41(14,79)$ & 16,40 & $106-136$ \\
\hline 2 & 177 & - & $7,01^{\mathrm{NS}}$ & & - & - \\
\hline 3 & 288 & LEI169-LEI106 & $7,72^{\dagger}$ & $-57,87(20,82)$ & 3,87 & $15-372$ \\
\hline \multicolumn{7}{|c|}{$P A-124^{\star *}$ e $365^{*} c M$} \\
\hline 1 & 124 & MCW18-ADL150 & $26,97^{\star \star}$ & $8,46(1,63)$ & 12,80 & $98-137$ \\
\hline 2 & 86 & - & $5,11^{\text {NS }}$ & & - & - \\
\hline 3 & 367 & MCW20-ROS25 & $12,66^{\dagger}$ & $-7,98(2,24)$ & 6,53 & $90-386$ \\
\hline \multicolumn{7}{|c|}{$P A a j^{3}-171^{\dagger}$ e $372^{* *} c M$} \\
\hline 1 & 133 & (nog & $5,07^{\mathrm{NS}}$ & Giv & - & - \\
\hline 2 & 294 & - & $6,05^{\text {NS }}$ & - & - & - \\
\hline 3 & 374 & MCW20 - ROS25 & $17,49^{\star *}$ & $-4,01(0,96)$ & 9,04 & $90-385$ \\
\hline \multicolumn{7}{|c|}{$P C-124^{\star *}$ e $291^{*} c M$} \\
\hline 1 & 124 & MCW18-ADL150 & $33,1^{\star *}$ & $29,67(5,16)$ & 15,35 & $106-136$ \\
\hline 2 & 179 & & $4,87^{\text {NS }}$ & & - & \\
\hline 3 & 292 & LEI169-LEI106 & $9,77^{\dagger}$ & $-22,63(7,24)$ & 4,99 & $36-363$ \\
\hline \multicolumn{7}{|c|}{ PPeit $-126^{* *}$ e $172^{*} c M$} \\
\hline 1 & 123 & MCW18-ADL150 & $36,53^{\star \star}$ & $24,33(4,02)$ & 16.74 & $107-135$ \\
\hline 2 & 178 & LEI138-MCW68 & $8,24^{\dagger}$ & $-10,59(3,69)$ & 2,53 & $22-305$ \\
\hline 3 & 276 & - & $5,78^{\mathrm{NS}}$ & - & - & - \\
\hline \multicolumn{7}{|c|}{$R-74^{*}$ e $124^{* *} c M$} \\
\hline 1 & 124 & MCW18-ADL150 & $35,09^{* *}$ & $26,21(4,42)$ & 16,15 & $105-139$ \\
\hline 2 & 74 & ADL234-LEI68 & $10,42^{\dagger}$ & $-11,61(3,60)$ & 3,27 & $28-261$ \\
\hline 3 & 292 & - & $3,91^{\mathrm{NS}}$ & $\begin{array}{c}1+, 0 \pm(0,0) \\
-\end{array}$ & - & -2 \\
\hline \multicolumn{7}{|c|}{$G A-175^{\dagger} \mathrm{cM}$} \\
\hline 1 & 105 & LEI146-LEI174 & $14,75^{\star}$ & $3,42(0,88)$ & 7,46 & \\
\hline & 392 & MCW20-ROS25 & $9,64^{\dagger}$ & $-1,59(0,77)$ & 1,83 & $80-392$ \\
\hline 2 & 177 & LEI138-MCW68 & $10,2^{\dagger}$ & $-3,00(0,94)$ & 3,19 & $73-340$ \\
\hline 3 & 0 & - & $2,33^{\mathrm{NS}}$ & - & - & - \\
\hline \multicolumn{7}{|c|}{$G A a j^{3}-388^{\dagger} c M$} \\
\hline 1 & 392 & MCW20-ROS25 & $6,7^{\dagger}$ & $-1,45(0,56)$ & 3,14 & $0-392$ \\
\hline 2 & 249 & ADL148-MCW36 & $7,71^{\dagger}$ & $-2,14(0,77)$ & 2,36 & $90-340$ \\
\hline 3 & 386 & MCW20-ROS25 & $11,05^{\dagger}$ & $2,65(0,80)$ & 5,71 & $74-392$ \\
\hline \multicolumn{7}{|c|}{$P P-124^{* *}$ e $370^{*} \mathrm{cM}$} \\
\hline 1 & 124 & MCW18-ADL150 & $29,81^{* *}$ & $4,76(0,87)$ & 14,0 & $105-128$ \\
\hline 2 & 86 & - & $6,66^{\mathrm{NS}}$ & - & - & - \\
\hline 3 & 370 & MCW20-ROS25 & $10,61^{\dagger}$ & $-4,20(1,29)$ & 5,44 & $91-390$ \\
\hline \multicolumn{7}{|c|}{$P P a j^{3}-380^{\dagger} c M$} \\
\hline 1 & 206 & - & $3,77^{\mathrm{NS}}$ & - & - & - \\
\hline 2 & 176 & - & $6,66^{\mathrm{NS}}$ & - & - & - \\
\hline 3 & 382 & MCW20-ROS25 & $10,8^{\dagger}$ & $-1,96(0,59)$ & 5,57 & $0-392$ \\
\hline
\end{tabular}


Tabela 25. Posições cromossômicas, estimativas do efeito de substituição do alelo, porcentagem da variância fenotípica explicada pelo QTL (V.F.) e intervalo de confiança (I.C.), dos QTLs para as características de carcaça que excederam o nível de ligação sugestiva em cada família de meio-irmãos Nos subtítulos (em itálico) são apresentadas as posições e a significância dos QTLs mapeados nas análises das famílias de meio-irmãos em conjunto

\begin{tabular}{|c|c|c|c|c|c|c|}
\hline Famila & Posição $^{2}$ & $\begin{array}{l}\text { Marcadores } \\
\text { flanqueadores }\end{array}$ & $\mathrm{F}^{1}$ & $\begin{array}{c}\text { Efeito de } \\
\text { substituição (EP) }\end{array}$ & V.F. (\%) & I.C. \\
\hline \multicolumn{7}{|c|}{$M o-85^{\dagger}$ e $370^{* *} c M$} \\
\hline $\begin{array}{l}1 \\
2\end{array}$ & $\begin{array}{c}264 \\
86\end{array}$ & MCW36-LEI169 & $\begin{array}{c}6,7^{\dagger} \\
4,57^{\mathrm{NS}}\end{array}$ & $\begin{array}{c}-1,41(0,54) \\
-\end{array}$ & 3,12 & $\begin{array}{c}79-332 \\
-\end{array}$ \\
\hline 3 & 370 & MCW20-ROS25 & $21,69 * \star$ & $-3,45(0,74)$ & 11,02 & $45-386$ \\
\hline \multicolumn{7}{|c|}{ Mo. $a j^{3}-165^{\dagger}$ e $373^{*} c M$} \\
\hline 1 & 274 & - & $3,82^{\text {NS }}$ & - & - & - \\
\hline 2 & 164 & - & $6,66^{\mathrm{NS}}$ & - & - & - \\
\hline 3 & 372 & MCW20-ROS25 & $17,62^{\star \star}$ & $-2,79(0,67)$ & 9,10 & $57-391$ \\
\hline \multicolumn{7}{|c|}{ Fig $-89^{*}$ e $128^{\star *} c M$} \\
\hline 1 & 114 & LEI146-LEl174 & $36,08^{\star \star}$ & $4,33(0,72)$ & 16,54 & $104-134$ \\
\hline 2 & 28 & - & $4,15^{\mathrm{NS}}$ & - & - & - \\
\hline 3 & 361 & - & $6,31^{\mathrm{NS}}$ & - & - & - \\
\hline \multicolumn{7}{|c|}{ Fig. $a j^{3}-170^{*} c M$} \\
\hline 1 & 110 & - & $4,82^{\mathrm{NS}}$ & - & - & - \\
\hline 2 & 170 & LEI138-MCW68 & $15,27^{*}$ & $1,48(0,38)$ & 4,88 & $130-250$ \\
\hline 3 & 196 & - & $2,71^{\mathrm{NS}}$ & - & - & - \\
\hline \multicolumn{7}{|c|}{ Pul $-68^{* *}$ e $100^{* *} \mathrm{cM}$} \\
\hline 1 & 66 & ADL188-ADL234 & $24,28^{\star \star}$ & $-1,20(0,38)$ & 4,76 & $94-115$ \\
\hline 2 & $\begin{array}{c}101 \\
86\end{array}$ & LEI146-LEI174 & $\begin{array}{l}37,82^{\star *} \\
6,47^{\mathrm{NS}}\end{array}$ & $2,74(0,41)$ & 20,17 & - \\
\hline 3 & 294 & - & $4,13^{\mathrm{NS}}$ & - & - & - \\
\hline \multicolumn{7}{|c|}{ Pul.aj ${ }^{3}-93^{\dagger} c M$} \\
\hline 1 & 97 & LEI146-LEI174 & $13,91^{*}$ & $1,04(0,28)$ & 6,83 & $95-115$ \\
\hline 2 & 86 & - & $2,94^{\mathrm{NS}}$ & - & - & - \\
\hline 3 & 206 & - & $2,32^{\mathrm{NS}}$ & - & - & - \\
\hline \multicolumn{7}{|c|}{ Cor $-107^{* *} \mathrm{cM}$} \\
\hline 1 & 115 & LEI146-LEI174 & $18,69^{* *}$ & $1,02(0,24)$ & 9,09 & $99-332$ \\
\hline 2 & 32 & & $3,95^{\mathrm{NS}}$ & - & - & - \\
\hline 3 & 96 & LEI146-LEI174 & $11,61^{\dagger}$ & $-0,72(0,21)$ & 5,97 & $33-360$ \\
\hline \multicolumn{7}{|c|}{ Cor.aj ${ }^{3}-101^{\dagger} c M$} \\
\hline 1 & 311 & - & $2,85^{\mathrm{NS}}$ & - & - & - \\
\hline 2 & 379 & - & $2,48^{N S}$ & - & - & - \\
\hline 3 & 99 & LEI146-LEI174 & $10,92^{\dagger}$ & $-0,61(0,19)$ & 5,64 & $37-279$ \\
\hline
\end{tabular}




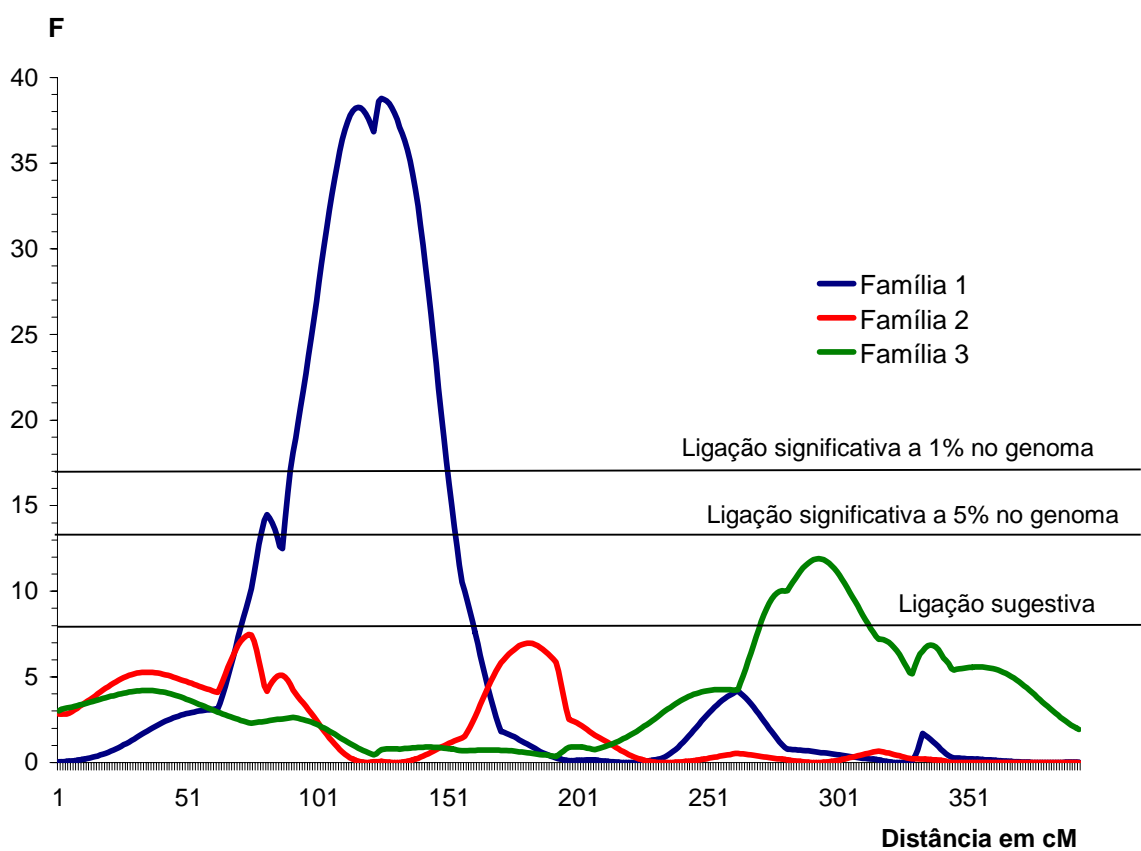

Figura 17 - Distribuição dos valores do teste estatístico no cromossomo 1 da análise de QTL para P42 utilizando o modelo de meio-irmãos (análise de cada família individualmente). As posições são dadas segundo o mapa construído no presente estudo e o nível de significância é dado considerando todo o genoma

Um QTL para P42 foi mapeado a $124 \mathrm{cM}$ na família 1. Nesta mesma família foram mapeados QTLs para C, PA, PC, PPeit, R, PP (Tabela 25) praticamente na mesma posição. De Koning et al. (2003) afirmaram que se um mesmo QTL está afetando várias características, é esperado que as mesmas famílias estejam segregando para este QTL quando associado a diferentes características. Na Figura 18 estão representados QTLs para algumas características mapeados na mesma região para a família 1. O que sugere que este seja um mesmo QTL controlando parte da variabilidade destas características.

Na Figura 18 é possível observar que há um QTL sugestivo na família 1 para CA que está posicionado em uma região distinta a 309 cM (Tabela 24), o que indica esta região como candidata para estudos futuros para identificar genes que influenciem CA, que é uma característica de grande interesse para indústria avícola. 


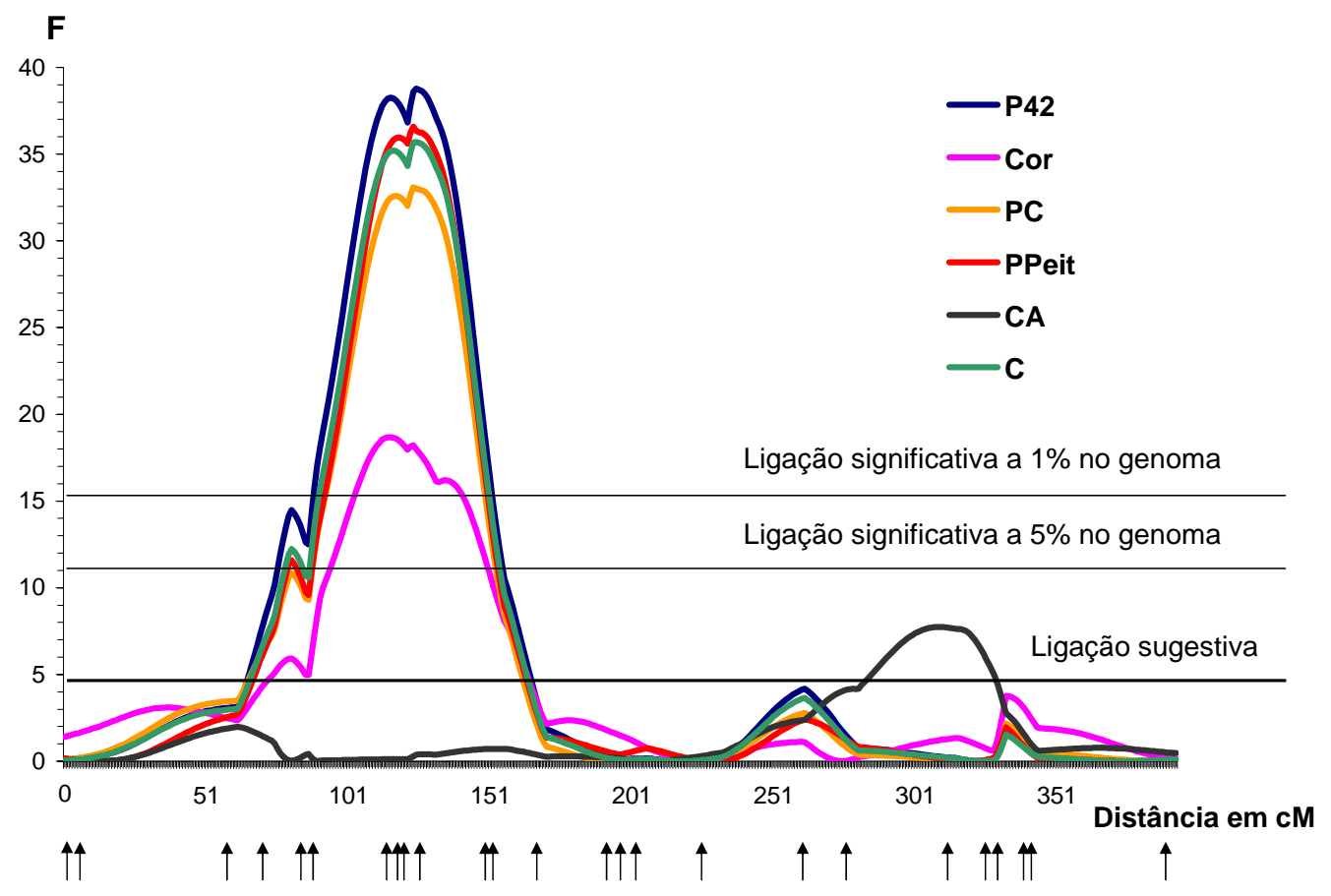

Figura 18 - Valores do teste estatístico da análise de QTLs no cromossomo 1 utilizando o modelo de meio-irmãos (Família1) para P42, C, PC, PPeit, Cor e CA . As posições são dadas segundo o mapa construído no presente estudo e o nível de significância é dado considerando todo o genoma. As setas indicam as posições dos marcadores

Alguns marcadores já associados anteriormente em outras populações foram associados a QTLs no presente estudo. Os marcadores LEI 68, ADL188, MCW18 e LEI 106 foram associados a peso corporal a 3, 6 e 9 semanas por Sewalen et al. (2002) em um cruzamento de linhagens de corte e postura. No presente estudo esses marcadores foram associados a peso corporal, mas também ao peso de partes da carcaça, o que sugere que nesta região estejam situados genes que controlam o crescimento global da ave, ou genes que controlam as diferentes características, mas que estejam muito próximos (ligados).

Van Kaam et al (1999a) associaram o marcador MCW58 a peso corporal aos 48 dias de idade, a ganho de peso e consumo de ração. Neste estudo este marcador foi associado a GP, CR e Cl.

Os marcadores LEI174 e ROS25 foram associados à GA e GAaj. Respectivamente, no presente estudo. Ikeobi et al. (2002) associaram o ROS 25 a peso 
da gordura subcutânea e Jennen et al. (2004) o LEI174 ao peso da gordura abdominal as 10 semanas de idade. Isso indica que nas regiões próximas aos marcadores LEI174 e ROS25 existem genes que influenciam a deposição de gordura.

\subsection{Intervalo de Confiança}

Os intervalos de confiança foram calculados para todos os QTLs mapeados no modelo F2. Esses dados não são apresentados porque as análises realizadas utilizando a opção "Bootstrap with resampling" do programa QTL EXPRESS, para calcular o IC empírico (95\%) da posição do QTL, incluíram praticamente todo o segmento estudado. A Figura 19 apresenta o gráfico das 10.000 iterações realizadas para P42, pode-se observar que há três regiões que sugerem a posição de um provável QTL, que são semelhantes às posições dos 3 QTLs mapeados para peso corporal (Figura 20). O programa, entretanto, só fornece o intervalo total de confiança de $79 \mathrm{cM}$ a $340 \mathrm{cM}$. Como a interação QTL x famílias foi significativa na análise de F2, optou-se por calcular os intervalos de confiança dos QTLs para cada família (Tabelas 24 e 25) que, conforme discutido anteriormente, podem não estar segregando para o QTL ou segregando para diferentes QTLs. Na Figura 21 são apresentados os gráficos de iterações para o cálculo do intervalo de confiança dos QTL para P42 nas duas famílias em que foram mapeados.

Mesmo os intervalos de confiança sendo calculados para cada família, estes ainda se mostraram extensos para algumas características nas famílias. Uma possível explicação para isso é que para alguns destes intervalos de confiança o QTL foi apenas sugestivo, talvez não sendo possível com o tamanho da população utilizada (famílias contendo 186, 289 e 170 animais) detectar com maior precisão a posição de QTLs de menor efeito (Tabelas 24 e 25). Em outras palavras, o menor número de indivíduos

utilizados nestas análises pode ter reduzido o poder de teste. Este fato pode ser observado na Figura 21. O QTL mapeado na família 1 (a) tem um IC menor (de 105 a $137 \mathrm{cM}$ do que o QTL mapeado na família 3 (b), de 3 a $376 \mathrm{cM}$. Se observarmos na Tabela 24 o QTL mapeado na família 1 explica 17,07\% da variância fenotípica total, já o mapeado na família 3 explica somente $3,78 \%$. 


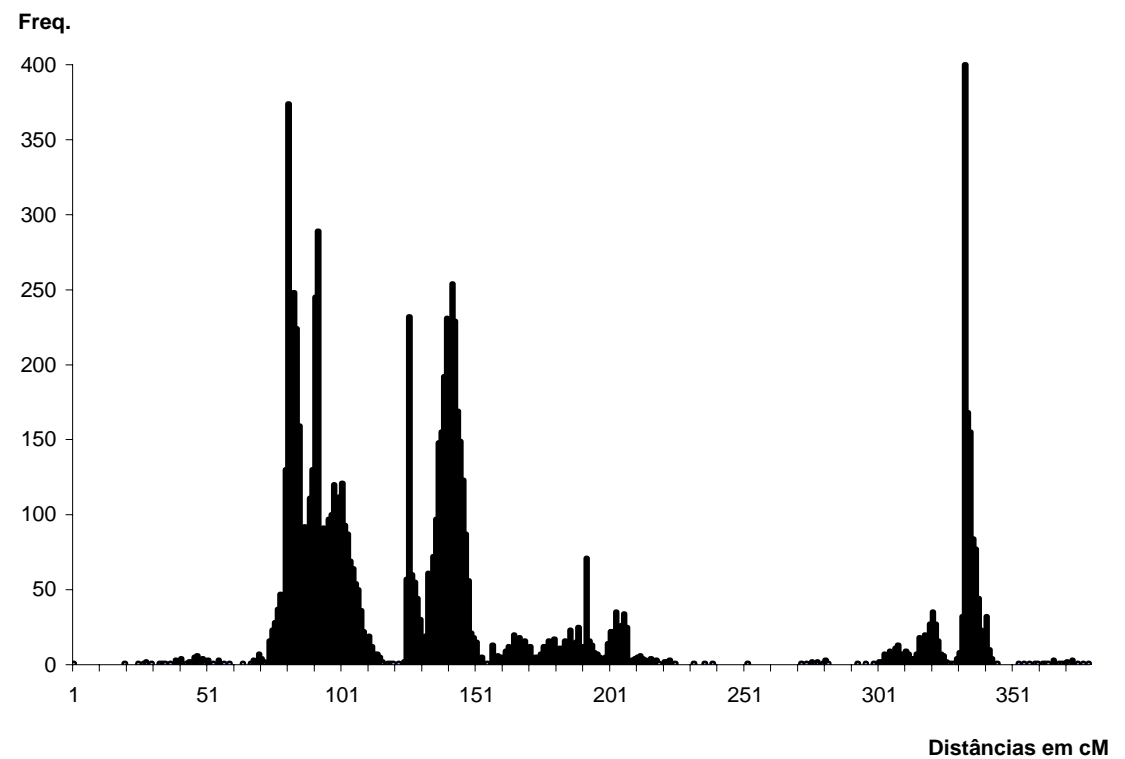

Figura 19 - Resultado da análise bootstrap com reamostragem para a determinação do intervalo de confiança para os QTLs para P42 mapeados no cromossomo 1

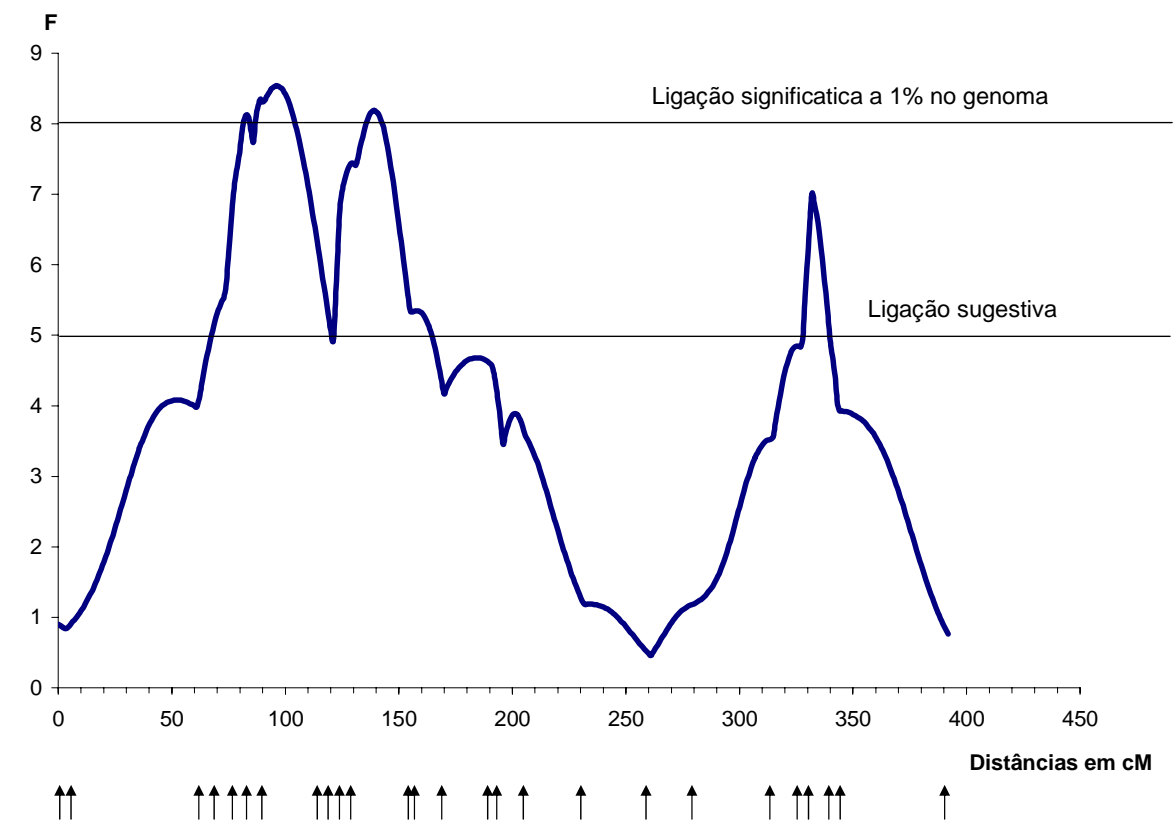

Figura 20 - Valores do teste estatístico da análise de QTLs para P42 no cromossomo 1 utilizando o modelo genético de F2 (7 famílias de irmão completos). As posições segundo o mapa construído e o nível de significância é dado considerando todo o genoma. As setas indicam as posições dos marcadores 


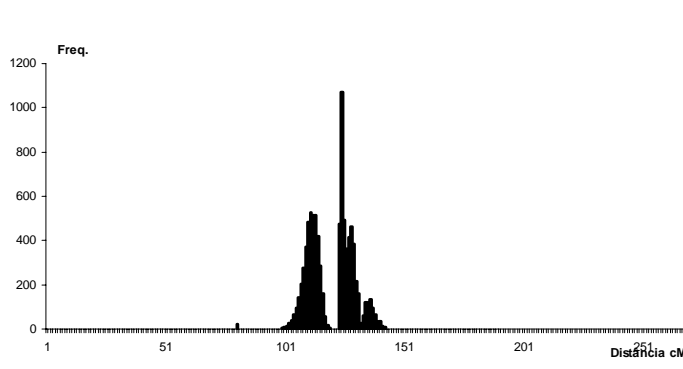

a)

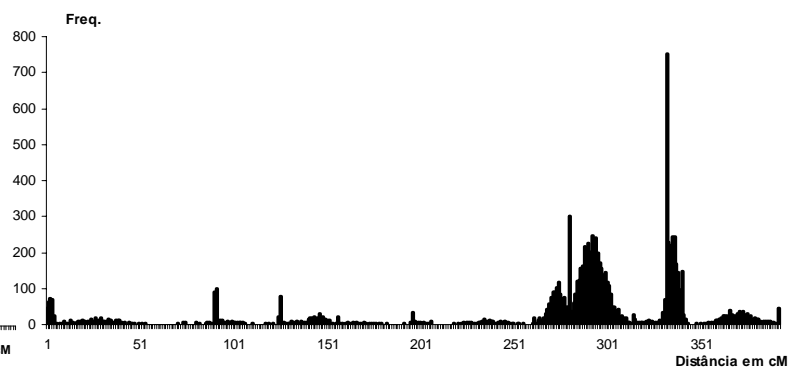

b)

Figura 21 - Resultado da análise bootstrap com reamostragem para a determinação do intervalo de confiança para os QTLs para P42 mapeados no cromossomo 1. a) Família 1 (macho 7716), b) Família 3 (macho 7822)

\subsection{Comparação dos QTLs mapeados com a genotipagem seletiva}

Na Figura 22 é apresentado o gráfico dos marcadores utilizados na genotipagem seletiva e os marcadores flanqueadores. As setas representam todos os QTLS mapeados no presente estudo. É possível observar que a maioria dos QTLs mapeados na análises F2 (setas em vermelho) e meio-irmãos (setas em preto) se concentraram nas regiões em que os marcadores foram associados na genotipagem seletiva.

Entre os marcadores utilizados como flanqueadores, os marcadores MCW208, MCW10 e ROS25 foram inseridos por segurança, na tentativa de não se perder QTLs, pois nestas regiões não haviam sido associados marcadores com P42 AJU na genotipagem seletiva, mas, Sewalen et al. (2002) e Ikeobi et al. (2002) encontraram QTLs nestas regiões. Conforme pode ser observado nas Tabelas 18 e 19, na análise de F2 foram encontrados QTLs associados a estes marcadores para CI, PAaj e GAaj e para Pul. Na análise de meio-irmãos (Tabelas 24 e 25) QTLs para Cl, Claj, PA, PAaj, GA, GAaj, PP, PPaj, Mo e Mo.aj, foram detectados nas regiões próximas a estes marcadores, evidenciando que a genotipagem seletiva não identificou regiões que continham QTLs para características com menor correlação com P42. 


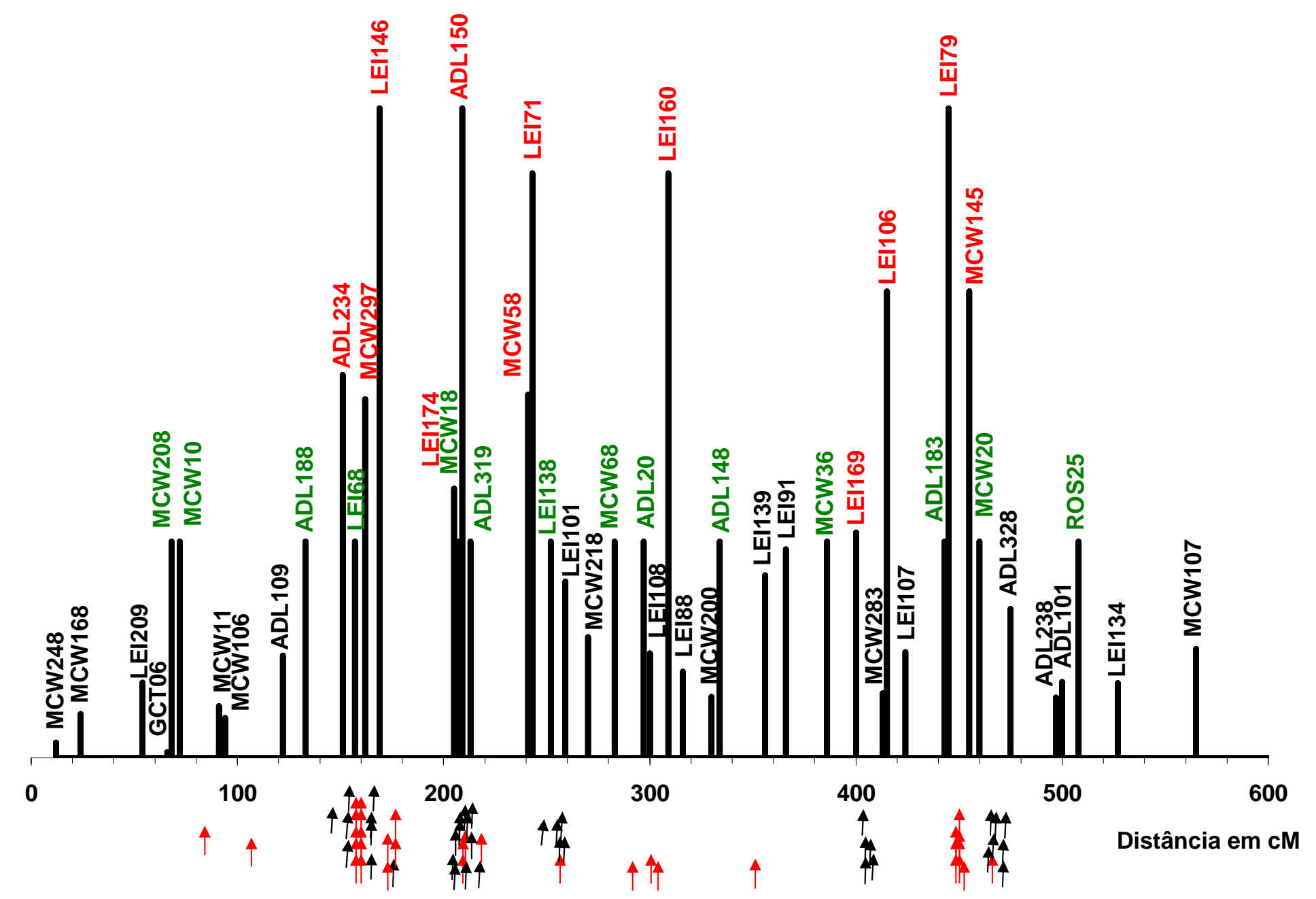

Figura 22 - Esquema onde são apresentados os marcadores utilizados no mapeamento de QTLs (em vermelho e verde). As setas indicam todos os QTLs mapeados na análise de F2 (em vermelho) e os QTLs mapeados na análise de meioirmãos (em preto). Distâncias em cM segundo mapas CN, W, C e E 


\subsection{Considerações finais e implicações}

Apesar do mapeamento de QTL necessitar de uma maior precisão para chegar ao gene (mutação) que está causando a variabilidade fenotípica, alguns marcadores associados neste estudo já foram identificados em diferentes populações, como estando associados a QTLs. Conforme apresentado na Figura 22, é possível visualizar duas regiões distintas onde se concentram a grande maioria dos QTLs mapeados no presente estudo: uma primeira região entre 120 e 220 cM, segundo as distâncias dos mapas CN, W, C ou E, e a segunda região entre 400 e 500 cM. Possivelmente existam genes nestas regiões que controlam as características de peso vivo e peso de partes, que são correlacionadas entre si, podendo ser apenas dois genes ou dois grupos de genes distintos que estejam causando o efeito dos QTLs para essas características.

Uma suposição pode ser levantada quanto aos genes IGF-1 (Insulin growth factor -1) e GH (Growth hormone) que estão situados no cromossomo 1 (http://poultry.mph.msu.edu/). O gene IGF-1 foi mapeado a $172 \mathrm{cM}$ segundo o mapa da população E. O gene $G H$ ainda não foi mapeado, entretanto, segundo o mapa citogenético, estes dois genes estão posicionados em braços opostos do cromossomo 1. Esse fato fortalece a hipótese do $G H$ estar próximo à segunda região, onde grande número de QTLs relacionados a peso corporal e peso de partes foram mapeados.

Os QTLs mapeados para CA e GA merecem ser ressaltados pela importância dessas características para a indústria avícola. A conversão alimentar é uma medida que representa animais mais eficientes, que aproveitam melhor 0 alimento, transformando-o em carne ou ovos. Este ponto é importante para a indústria avícola, pois os gastos com ração representam a maior parte dos custos de produção na avicultura. A seleção direta para CA é dificultada pelo fato da necessidade de avaliação do consumo individual de um grande número de animais. A redução da gordura abdominal, que está associada com a redução no teor de gordura na carcaça, é uma exigência do mercado consumidor nos dias de hoje. Como a gordura abdominal é positivamente correlacionada com peso corporal, a seleção para aumento da taxa de crescimento tem sido acompanhada pelo aumento da gordura abdominal, o que tem dificultado a melhoria dessa característica. Neste estudo, foram mapeados QTLs para estas características mesmo depois delas terem sido ajustadas para peso corporal, o que indica que parte da variância fenotípica destas características é controlada por 
genes distintos daqueles que controlam o crescimento. Como as características CA e GA são difíceis de serem selecionadas pelos métodos tradicionais, as regiões associadas a QTLs devem ser investigadas mais detalhadamente com o objetivo de identificar os genes que influenciam estas características, visando a posterior utilização dessa informação na seleção assistida por marcadores.

Embora genes que influenciam diretamente a deposição de gordura não tenham ainda sido mapeados no cromossomo 1 da galinha, Schmid et al. (2000) demonstraram regiões desse cromossomo que apresentam alta sintenia com partes dos cromossomos 12 e 22 de humanos em que foram identificados alguns genes que participam de vias intermediárias do metabolismo de gordura em outras espécies. Estes, por sua vez, podem ser considerados como potenciais genes candidatos para explicar diferenças fenotípicas na deposição de gordura observada entre indivíduos. São eles: PPARA (peroxisome proliferative actived receptor- $\alpha$ ), IGF-I (insulin-like growth factor), HMGIC (high mobility group I-C), LDHB (lactate dehydrogenase B) e GAPDH (glyceraldehyde-3-phosphate dehydrogenase).

Estudos utilizando métodos estatísticos mais precisos como análises multicaracteres têm sido propostos por Jiang e Zeng (1995), Weller (1996), Knott \& Haley (2000) e Korol et al. (2001). Este tipo de análise poderia fornecer maior conhecimento sobre a natureza das correlações genéticas entre as características aqui apresentadas. Entretanto, segundo Schrooten e Bovenhuis (2002), a aplicação desta metodologia ainda não é prática comum, pois apresenta dificuldades computacionais principalmente para populações não endogâmicas e quando o número de características analisadas for grande.

QTLs mapeados para algumas características (PPeit, PC, PA, Cl, Mo, Pul, Fig, Cor) neste estudo não foram até o momento descritos na literatura. Estas características foram analisadas com e sem a covariável peso vivo incluída no modelo para melhor entender parte do controle genético exercido sobre estas características. Quando a covariável foi incluída no modelo foram mapeados QTLs apenas para as características Claj, PAaj, PPaj, Mo.aj, Pul.aj e Cor.aj, o que sugere que nestas regiões existam genes que tem efeito sobre o desenvolvimento destas características independente dos genes que influenciam o peso vivo. Os QTLs mapeados no cromossomo 1 para características PPeit e PC parecem conter os mesmos genes ou grupo de genes que influenciam o peso corporal. 
Os QTLs mapeados para Cor.aj e Pul.aj sugerem a presença de genes que influenciam o desenvolvimento do coração e pulmão, independente do peso vivo. A identificação destes genes poderia auxiliar na redução de problemas metabólicos como a ocorrência de ascite, que causa grande perda econômica na avicultura. Estudos mais detalhados das regiões onde foram mapeados esses QTLs permitirão identificar os genes que estão influenciando estas características, entender melhor seu controle genético e, dessa forma, utilizar estas informações de maneira eficiente em programas de melhoramento animal.

Outro resultado importante deste estudo é que mesmo se tratando de linhagens divergentes (corte e postura), selecionadas para características distintas, muitas delas correlacionadas negativamente, os alelos dos QTLs não estão fixados nas linhagens. A existência de variabilidade nestes locos dentro de linhagens, mesmo após várias gerações de seleção, confirma a importância de se estudar QTLs para o melhoramento genético animal. 


\section{CONCLUSÕES}

1. O mapa de ligação do cromossomo 1, construído para a população estudada, apresentou o mesmo ordenamento de marcadores do mapa consenso, mas com pequenas discrepâncias em relação aos mapas $\mathrm{E}, \mathrm{C}$ e W.

2. Foram mapeados QTLs no cromossomo 1 que não haviam sido descritos na literatura anteriormente, como peso de partes (peito, coxas e sobrecoxas, asas, pés), peso de órgãos (fígado, moela, pulmão e coração) e comprimento de intestino. Foram também mapeados QTLs em regiões já descritas em outras populações para peso vivo, ganho de peso, consumo de ração e peso da gordura abdominal.

3. As linhagens TT e CC não estão fixadas para alelos alternativos dos QTLs mapeados no cromossomo 1 da galinha.

4. Os QTLs mais importantes mapeados neste estudo são os para conversão alimentar e peso da gordura abdominal ajustados para peso corporal. Estas características são de grande importância para a industria avícola, porém difíceis de serem melhoradas por métodos tradicionais de seleção.

5. Marcadores já associados a QTLs em outras populações foram confirmadna nn presente estudo, sugerindo estas regiões como candidatas a estudos futur identificação de genes e mutações causais. 
ANEXOS 


\section{ANEXO A - Medotologia Hillel et al. (1989). Para extração de DNA de sangue de aves}

1. Colocar $50 \mu \mathrm{L}(200 \mu \mathrm{L})$ de sangue em tubos falcon de $15 \mathrm{~mL}$.

2. Adicionar a cada alíquota $3 \mathrm{~mL}(4 \mathrm{~mL})$ de THE (10 mM Tris, $100 \mathrm{mM}$ EDTA), homogeneizar por inversão do tubo algumas vezes, adicionar $10 \mu \mathrm{L}$ de proteinase $\mathrm{K}(20 \mathrm{mg} / \mathrm{mL})$ e $30 \mu \mathrm{L}(40 \mu \mathrm{L})$ de SDS 20\%. Incubar em shaker a 55 ${ }^{\circ} \mathrm{C}$ por 12 horas.

3. Adicionar $3 \mathrm{~mL}(4 \mathrm{~mL}$ ) de $\mathrm{PCl}$ (fenol :clorofórmio :isoamil, 25:24:1). Misturar bem e colocar em banho-maria a $55^{\circ} \mathrm{C}$ por 10 minutos. Remover os tubos do banho e misturar novamente.

4. Centrifugar os tubos a $2500 \mathrm{rpm}$ por 10 minutos.

5. Com o auxilio de uma pipetadora, transferir a fase aquosa para um novo tubo e extrair novamente com $3 \mathrm{~mL}(4 \mathrm{~mL})$ de $\mathrm{PCl}$.

6. Centrifugar os tubos a $2500 \mathrm{rpm}$ por 10 minutos.

7. Com o auxílio de uma pipetadora, transferir a fase aquosa para um novo tubo e extrair com $3 \mathrm{~mL}(4 \mathrm{~mL})$ de $\mathrm{Cl}(24: 1)$.

8. Centrifugar os tubos a 2500 rpm por minuto.

9. Com o auxílio de uma pipetadora transferir a fase aquosa para um novo tubo.

10. Adicionar $0,3 \mathrm{~mL}(0,4 \mathrm{~mL})$ de $\mathrm{NaCl} 5 \mathrm{M}$.

11. Adicionar $6 \mathrm{~mL}(8 \mathrm{~mL}$ ) de Álcool 95\% (deverá aparecer a nuvem de DNA neste momento).

12. Centrifugar os tubos à 3500 rpm por 10 minutos e descartar o sobrenadante.

13. Adicionar $5 \mathrm{~mL}$ de etanol $70 \%$ e agitar.

14. Centrifugar os tubos à 3500 rpm por 5 minutos e descartar o sobrenadante.

15. Secar os tubos a temperatura ambiente ou $37^{\circ} \mathrm{C}$ (se secar demais não irá ressuspender).

16. Adicionar $3 \mathrm{~mL}$ de TE aos peletes de DNA. Colocar os peletes para ressuspender "overnight" em um shaker.

17. Ler em espectofotômetro e testar a integridade do DNA em gel de agarose $0,8 \%$. 


\section{ANEXO B - Método modificado de Hillel, para extração de DNA de sangue de aves}

1. Descongelar a amostra de sangue a $37^{\circ} \mathrm{C}$;

2. Adicionar $200 \mu \mathrm{L}$ de SSC $1 \mathrm{X}$ em $20 \mu \mathrm{L}$ de sangue;

3. Centrifugar por 2 minutos a $12.000 \mathrm{rpm}$;

4. Descartar o sobrenadante;

5. Ressuspender as células em $200 \mu \mathrm{L}$ de SSC 1X;

6. Centrifugar por 2 minutos a $12.000 \mathrm{rpm}$;

7. Descartar o sobrenadante;

8. Acrescentar $500 \mu \mathrm{L}$ de acetato de sódio; agitar levemente até dissolver o precipitado;

9. Adicionar $50 \mu \mathrm{L}$ de SDS 10\%; misturar cuidadosamente por inversão;

10. Adicionar $500 \mu \mathrm{L}$ de fenol clorofórmio (na capela); misturar bem até homogeneizar;

11. Centrifugar por 10 minutos a $12.000 \mathrm{rpm}$;

12. Recuperar o sobrenadante e transferi-lo para outro eppendorf;

13. Adicionar $1 \mathrm{~mL}$ de etanol absoluto; misturar por inversão; deixar precipitar a -20 ${ }^{\circ} \mathrm{C}$ durante 1,5 horas;

14. Centrifugar por 2 minutos a $12.000 \mathrm{rpm}$;

15. Descartar o etanol absoluto;

16. Lavar o precipitado com $500 \mu \mathrm{L}$ de etanol $70 \%$;

17. Centrifugar por 2 minutos a $12.000 \mathrm{rpm}$;

18. Descartar o etanol 70\%;

19. Colocar o precipitado em estufa a $37^{\circ} \mathrm{C}$ por meia hora;

20. Ressuspender o precipitado em $300 \mu \mathrm{L}$ de TE. 


\section{ANEXo C - EXTRAÇÃO DE DNA de SANGUe de AVES POR DNAZOIB (Reagente para lise com solução detergente de guanidina)}
1) Aliquotar $15 \mu \mathrm{L}$ de sangue em EDTA;
2) Adicionar $1 \mathrm{~mL}$ de DNAzol;
3) Agitar manualmente;
4) Dividir em 2 eppendorfs;
5) Adicionar mais $500 \mu \mathrm{L}$ de DNAzol nos tubos;
6) Dividir novamente em 2 tubos;
7) Adicionar $500 \mu \mathrm{L}$ de etanol absoluto;
8) Inverter os tubos várias vezes para misturar bem;
9) "Pescar" o DNA com uma pipeta;

10) Lavar duas vezes com $1 \mathrm{ml}$ de ETANOL 95\%;

11) Centrifugar a $3000 \mathrm{rpm}$ por 10 minutos;

12) Decartar o sobrenadante e secar os tubos a $37^{\circ} \mathrm{C}$ por meia hora;

13) Ressuspender com $300 \mu \mathrm{L}$ de água milliQ;

\section{ANEXO D - EXTRAÇÃO DE DNA DE AVES POR DNAzol® (Reagente para lise com solução detergente de guanidina)}

1) Aliquotar $15 \mu \mathrm{L}$ de sangue coletado em EDTA;

2) Adicionar $1 \mathrm{~mL}$ de DNAzol;

3) Agitar manualmente;

4) Dividir em dois tubos (500 $\mu \mathrm{L}$ em cada um);

5) Adicionar $500 \mu \mathrm{L}$ de etanol absoluto;

6) "Pescar" o DNA com o Auxílio de uma pipeta;

7) Lavar com $1 \mathrm{~mL}$ de etanol 95\%;

8) Centrifugar por 10 minutos a $1000 \mathrm{~g}$;

9) Repetir os passos 7 e 8;

10) Ressuspender o pelete com $300 \mu \mathrm{L}$ de água. 


\section{ANEXO E - EXTRAÇÃO DE DNA UTILIZANDO PROTEINASE K:}

1. Aliquotar $20 \mu \mathrm{L}$ de sangue;

2. Adicionar 1,0 mL de tampão de lise de células vermelhas;

3. Centrifugar por 1 minuto a $13000 \mathrm{rpm}$. Descartar o sobrenadante e repetir os passos 1 e 2;

4. Lavar o pelete com $0,5 \mathrm{~mL}$ de água destilada;

5. Centrifugar 1 minuto, 13000 rpm; descartar o sobrenadante;

6. Ressuspender o pelete em $80 \mu \mathrm{L}$ do tampão de proteinase-K (5x), $7 \mu \mathrm{L}$ de proteinase-K (20mg/mL), $10 \mu \mathrm{L}$ de SDS $20 \%$ e $283 \mu \mathrm{L}$ de água destilada;

7. Incubar por 1 hora a $55^{\circ} \mathrm{C}$;

8. Adicionar $120 \mu \mathrm{L} \mathrm{NaCl} 5 \mathrm{M}$ e agitar no "vortex" por 15 segundos. Centrifugar a 13000 rpm por 5 minutos;

9. Transferir o sobrenadante para um novo tubo e adicionar $1 \mathrm{~mL}$ de etanol absoluto. Homogenenizar e centrifugar por 5 minutos a 13000 rpm;

10. Lavar com etanol 70\%; centrifugar a 13000 rpm por 3 minutos;

11. Descartar o sobrenadante, secar o pelete 15 minutos à temperatura ambiente; ressuspender em água.

\section{Tampão de proteinase-K}

- $\quad 0,375 \mathrm{M} \mathrm{NaCl}$

0,12 M EDTA $(\mathrm{pH} 8,0)$ 


\section{REFERÊNCIAS BIBLIOGRÁFICAS}

ANDERSSON, L.; GEORGES, M. Domestic-animal genomics: deciphering the genetics of complex traits. Nature Reviews Genetics, v.5, p.202-212, 2004.

ALFONSO, L. e HALEY, C.S. Power of different F2 schemes for QTL detection in livestock. Animal Science, v.66, p.1-8, 1998.

ARÚS, P.; MORENO-GONZÁLEZ, J. Plant breeding: principles and prospects. Ed. M.D. Hayward, N.O. Bosemark and I. Romagosa, London, 1993. 250p

ASSOCIAÇÃO BRASILEIRA DOS EXPORTADORES DE FRANGO. Estatísticas www.abef.com.br (21 abr. 2003).

BETERCHINI, A.G. Mitos e verdades sobre ovos de consumo. In: CONFERÊNCIA APINCO 2003 DE CIENCIA E TECNOLOGIA AVÍCOLAS, Campinas, 2003. Anais. Campinas: FACTA, 2003. p. 19-26.

BOVENHUIS, H.; SPELMAN, R. J. Selective genotyping to detect trait loci for multiple traits in outbred populations. Journal of Dairy Science, v.83, p.173-180, 2000.

BURT, D.W. Applications of biotechnology in the poultry industry. World's Poultry Science Journal, v.58, n.1, p.5-13, 2002.

CHENG, H.H.; LEVIN, I.; VALLEJO, R.L.; KHATIB, H.; DODGSON, J.B.; CRITTENDEN, L.B.; HILLEL,J. Development of a genetic map of the chicken with markers of high utility. Poultry Science, v.74, p.1855-1874, 1995. 
CHURCHILL, G.A.; DOERGE, R.W. Empirical threshold values for quantitative trait mapping. Genetics, v.138, p.963-971, 1994.

COELHO, A.S.G.; SILVA, H.D. Construção de mapas genéticos e mapeamento de QTLs. Piracicaba: ESALQ, 2002. 66p.

CROOIJMANS, R.P.M.A.; GROEN, A.B.F.; VAN KAMPEN, A.J.A.; VAN DER BEEK, S.; VANDER POEL, J.J.; GROENEN, M.A.M. Microsatellite polymorphism in commercial broiler and layer lines estimated using pooled blood samples. Poultry Science, v.75, p.904-909, 1996.

CROOIJMANS, R. Gene hunting: molecular analysis of the chicken genome. Wageningen, 2000. 150p Thesis (Ph.D.) - Wageningen University.

DARVASI, A.; SOLLER, M. Selective genotyping for determination of linkage between a marker locus and quantitative trait locus. Theoretical and Applied Genetics, v.85, p.353-359, 1992.

DEKKERS, J.C.M; HOSPITAL, F. The use of molecular genetics in the improvement of agricultural populations. Nature Reviews Genetics, v.3, p.22-32, 2002.

DE KONING, D.J.; HARLIZIUS, B.; RATTINK, A.P.; GROENEN, M.A.M.; BRASCAMP, E.W.; VAN ARENDONK, J.A.M. Detection and characterization of quantitative trait loci for meat quality traits in pigs. Journal of Animal Science, v.79, p.2812-2819, 2001.

DE KONONIG, D. J.; WINDSOR, D.; HOCKING, P.M.; BURT, D. W.; LAW, A.; HALEY, C. S.; MORRIS, A.; VINCENT, J.; GRIFFIN, H. Quantitative trait locus detection in commercial broiler lines using candidate regions. Journal of Animal Science, v.81, p.1158-1165, 2003. 
DE KONING, D.J.; JANSS, L.L.G.; RATTINK, A.P.; VAN OERS, P.A.M.; VRIES, B.J. de; GROENEN, M.A.M.; VAN DER POEL, J.J.; GROOT, P.N. de; BRASCAMP, E.W.; VAN ARENDONK, J.A.M. Detection of quantitative trait loci for backfat thickness and intramuscular fat content in pigs (Sus scrofa). Genetics, v.152, p.1679-1690, 1999

FALCONER, D.S.; MACKAY, T.F.C. Introduction to quantitative genetics. Harlow: Longman Group, 1996. 464p.

FERREIRA, M.E.; GRATTAPAGLIA, D. Introdução ao uso de marcadores moleculares em análise genética. 3.ed. Brasília: Embrapa,CENARGEN, 1998. $220 p$.

GREEN, P.; FALLS, K.; CROOKS, S. CRI-MAP VERSION 2.4. St. Louis: University School of Medicine, 1990.

GROENEN, M.A.M.; CROOIJMANS, R.P.M.A.; VEENENDAAL, A.; CHENG, H.H.; SIWEK, M.; VAN DER POEL, J.J. A comprehensive microsatellite linkage map of the chicken genome. Genomics, v.49, p.265-274, 1998.

GROENEN, M.A.M.; CHENG, H.H.; BUMSTEAD, N.; BENKEL, B.F.; BRILES, W.E.; BURKE, T.; BURT, D.W.; CRITTENDEN, L.B.; DODGSON, J.; HILLEL, J.; LAMONT, S.; PONCE DE LEON, A.; SOLLER, M.; TAKAHASHI, H.; VIGNAL, A. A consensus linkage map of the chicken genome. Genome Research, v.10, p.137$147,2000$.

HALEY, C.S.; KNOTT, S.A. A simple regression method for mapping quantitative trait loci in line crosses using flanking markers, Heredity, v.69, p.315-324, 1992.

HALEY, C.S.; KNOTT, S.A.; ELSEN, J.M. Mapping quantitative trait loci in crosses between outbred lines using least squares, Genetics, v.136, p.1195-1207, 1994. 
HAMOEN, F.F.A.; VAN KAAM, J.B.C.H.M.; GROENEN, M.A.M.; VEREIJKEN, A.L.J. e BOVENHUIS, H. Detection of genes on the Z-chromosome affecting growth and feathering in broilers. Poultry Science, v.80, p.527-534, 2001.

HILLEL, J. Map-based quantitative trait locus identification. Poultry Science, v.76, p.1115-1120, 1997.

HILLEL, J.; PLOTZY, Y.; HABERFELD, U.; LAVI, U.; CAHANER,A.; JEFFREYS, A.J. DNA fingerprints of poultry. Animal Genetics, v.20, p.145-155, 1989.

IKEOBI, C.O.N.; WOOLLIAMS, J.A.; MORRICE, D.R.; LAW, A.; WINDSOR, D.; BURT, D.W.; HOCKING, P.M. Quantitative trait loci affecting fatness in the chicken. Animal Genetics, v.33, p428-435, 2002.

JENNEN, D. G. J.; VEREIJKEN, A. L. J.; BOVENHUIS, H.; CROOIJMANS, R.P.M.A.; VEENENDAAL, A.; VAN DER POEL, J. J.; GROENEN, M.A.M. Detection and localization of quantitative trait loci affecting fatness in broilers. Poultry Science, v.83, p.295-301, 2004.

JIANG, C.; ZENG, Z.B. Multiple trait analysis of genetic mapping for quantitative trait loci. Genetics, v.140, p.1111-1127, 1995.

KAISER, M.G.; DEEB, N.; LAMONT, S.J. Microsatellite markers linked to Salmonella enterica serovarar enteridis vaccine response in young F1 broiler-cross chicks. Poultry Science, v.81, p.193-201, 2002.

KERJE, S.; CARLBORG, Ö.; JACOBSSON, L.; SCHÜTZ, K.; HARTMANN, C.; JENSEN, P. ANDERSSON, L. The twofold difference in adult size between the red junglefowl and White Legorn chickens is largely explained a limited number of QTLs. Animal Genetics, v.34, p.264-274, 2003. 
KNOTT, S.A.; ELSEN, J.M.; HALEY, C.S. Methods for multiple-marker mapping of quantitative trait loci in half-sib populations. Theoretical and Applied Genetics, v.93, p71-80, 1996.

KNOTT, S.A.; HALEY, C.S. Multitrait least squares for quantitative trait loci detection. Genetics, v.156, p.899-911, 2000.

KIRKPATRICK, B. W.; MENGELT, A.; SCHULMAN, N.; MARTIN, I.C.A. Identification of quantitative trait loci for prolificacy and growth in mice. Mammalian Genome, v.9, p.97-102, 1998.

KOROL, A.B.; RONIN, Y.I.; NEVO, E.; HAYES, P. Enhanced efficiency of quantitative trait loci mapping analysis based on multivariate complexes of quantitative traits. Genetics, v.157, p.1789-1803, 2001.

KNOTT, S.A.; MARKLUND, L.; HALEY, C.A.S.; ANDERSSON, K.; DAVIES, W.; ELLEGREN, H.; FREDHOLM, M.; HANSSON, I.; HOYHEIM, B.; LUNDSTROM, K.; MOLLER, M.; ANDERSSON, L. Multiple marker of quantitative trait loci in a cross between outbred wild boar and large white pigs. Genetics, v.149, p.1069-1080, 1998.

LANDER, E. S.; BOTSTEIN, D.; Mapping mendelian factors underlying quantitative traits using RFLP linkage maps. Genetics, v.121, p.185-199, 1989.

LANDER, E.; KRUGLYAK, L. Genetic dissection of complex traits: guidelines for interpreting and reporting linkage results. Nature Genetics, v.11, p.241-247, 1995.

LEDUR, M.C.; ZANELLA, E.L.; SCHMIDT, G.S.; JAENISCH, F.R.F.; SAATKAMP, M.G.; BASSI, L.J.; COUTINHO, L.L. Peso e características de carcaça em linhagens utilizadas no desenvolvimento de populações referência para detecção de QTL em aves. Revista Brasileira de Ciência Avícola, supl. 2, p.73, 2000. 
LEDUR, M.C.; BERTANI, G.R.; NONES, K. Genômica nos programas de melhoramento genético Avícola. In: CONFERÊNCIA APINCO 2003 DE CIENCIA E TECNOLOGIA AVÍCOLAS, Campinas, 2003. Anais. Campinas: FACTA, 2003. p.87105.

LIU, B.H. Statistical genomics: linkage, mapping, and QTL analysis. Boca Raton: CRC Press, 1998. 611p.

LYNCH, M.; WALSH, B. Genetics and analysis of quantitative traits. Sunderland: Sinauer Associates, 1998. 980p.

MARIANI, P.; BARROW, P.A.; CHENG, H.H.; GROENEN, M.M.; NEGRINI, R.; BUMSTEAD, N. Localization to chicken chromosome 5 of a novel locus determining salmonellosis resistance. Immunogenetics, v.53, n.9, p.786-791, 2001.

McELROY, J.P.; HARRY, D.E.; DEKKERS, J.C.M.; LAMONT, S.J. Molecular markers associated with growth and carcass traits in meat-type chickens (compact disc). In: WORLD CONGRESS ON GENETICS APPLIED TO LIVESTOCK PRODUCTION, 7., Montpellier, 2002. Abstracts. Montpellier: s.ed., 2002.

MELO, C.M.R.; NONES, K.; LEDUR, M.C.; ZANELLA, E.L.; MOURA, A.S.M.; COUTINHO, L.L. Parâmetros genéticos e fenontípicos de caracters de desempenho e carcaça em um cruzamento experimental de linhagens de aves de corte e postura. In: 41a REUNIÃO ANUAL DA SOCIEDADE BRASILEIRA DE ZOOTECNIA, Campo Grande, 2004. Resumos. Campo Grande: SBZ, 2004.

MOODY, D.E.; POMP, D.; NIELSEN, M. K.; VAN VLECK, L.D. Identification of quantitative trait loci influencing traits related to energy balance in selection and inbred lines of mice. Genetics, v.152, p.699-711, 1999.

MURANTY, H.; GOFFINET, B.; SANTI, F. Multitrait and multipopulation QTL search using selective genotyping. Genetic Research of Cambridge, v.70, p.259-265, 1997. 
OHNO, Y.; TANASE, H.; NABIKA, T.; OTSUKA, K.; SASAKI, T.; SUZAWA, T.; MORII, T.; YAMORI, Y.; SARUTA, T. Selective genotyping with epistatic can be utilized form major quantitative trait locus mapping in hypertension in Rats. Genetics, v.155, p.785-792, 2000.

PRIMMER, C.R.; RAUDSEPP, T.; CHOWDHARY, B.P. Low frequency of microsatellites in the avian genome, Genome Research, v.7, p.471-482, 1997.

RABIE T.; CROOIJMANS, R.; VEREIJKEN, A.; ALBERS, G.; VEENENDAAL, T.; DIJKHOF.R.; VAN DER POEL, J.; BOVENHUIS, H.; GROENEN, M. Fine mapping of quantitative trait loci (QTL) affecting susceptibility to ascites in chicken. In: INTERNATIONAL CONFERENCE ON ANIMAL GENETICS, 28., Gottingen, 2002. Proceedings. Gottingen: s.ed., 2002. p.189.

SAS INSTITUTE. SASISTAT 2001: user's guide: statistics version 8.2; compact disc. Cary, 2001.

SCHMID, M.; NANDA, I.; GUTTENBACH, M.; STEINLEIN, C.; HOEHN, H.; SCHARTL, M.; HAAF, T.; WEIGEND, S.; FRIES, R.; BUERSTEDDE, J-M.; WIMMERS, K.; BURT, D.W.; SMITH, J.; A'HARA, S.; LAW, A.; GRIFFIN, D.K.; BUMSTEAD, N.; KAUFMAN, J.; THOMPSON, P.A.; BURKE, T.A; GROENEN, M.A.M.; CROOIJMANS, R.P.M.A.; VIGNAL, A.; FILLON, V.; MORRISON, M.; PITEL, F.; TIXIER-BOICHARD, M.; LADJALI-MOHAMMEDI, K.; HILLEL, J.; MAKI-TANILA, A.; CHENG, H.H.; DELANY, M.E.; BURNSIDE, J.; MIZUNO, S. First report on chicken genes and chromosomes 2000. Cytogenetics and Cell Genetics, v.90, p.169-218, 2000.

SCHROOTEN, C.; BOVENHUIS, H. Detection of pleiotropic effects of quantitative trait loci in outbred populations using regression analysis. Journal of Dairy Science, v.85, p.3503-3513, 2002. 
SEATON, G.; HALEY, C.S.; KNOTT, S.A.; KEARSEY, M.; VISSCHER, P.M. QTL Express: mapping quantitative trait loci in simple and complex pedigrees. Bioinformatics, v,18, n.2, p.339-340, 2002.

SEATON, G. QTL express. http : //qtl.cap.ed.ac.uk/ (20 abr. 2004)

SEWALEM, A.; MORRICE, D. M.; LAW, A.; WINDSOR, D.; HALEY, C. S.; IKEOBI, C. O. N.; BURT, D. W.; HOCKING, P. M. Mapping of quantitative trait loci for body weight at three, six and nine weeks of age in a broiler layer cross. Poultry Science, v.81, p.1775-1781, 2002.

SMITH, J.; BRULEY, C.K.; PATON, I.R.; DUNN, I.; JONES, C.T.; WINDSOR, D.; MORRICE, D.R.; LAW, A.S.; MASABANDA, J.; SAZANOV, D.; WADDINGTON, D.; FRIES, R.; BURT, D.W. Differences in gene density on chicken macrochromosomes and microchromosomes. Animal Genetics, v.31, p.96-103, 2000.

TATSUDA, K.; FUJINAKA, K.; Genetic mapping of the QTL affecting body weight in chickens using a F2 family. British Poultry Science, v.42, p.333-337, 2001.

TUISKULA-HAAVISTO, M.; HONKATUKIA, M.; KONING, D.J.; SCHULMAN, N.F.; MÄKI-TANILA, A. Mapping of quantitative trait loci affecting quality and production traits in eggs layers, Poultry Science, v.81, p.919-927, 2002.

VALLEJO, R.L.; BACON, L.D.; LIU, H.C.; WITTER, R.L.; GROENEN, M.A.M.; HILLEL, J.; CHENG, H.H. Genetic mapping of quantitative trait loci affecting susceptibility to marek's disease virus induced tumors in F2 intercross chickens, Genetics, v.148, p.349-360, 1998.

VAN DER BEEK.; VAN ARENDONK, J.A.M.; GROEN, A.F. Power of two and threegeneration QTL, mapping experiments in an outbred population containing full-sib or half-sib families. Theoretical and Applied Genetics, v.91, p.1115-1124, 1995. 
VAN KAAM, J.B.C.H.M.; VAN ARENDONK, J.A.M.; GROENEN, M.A.M.; BOVENHUIS, H.; VEREIJKEN, A.L.J.; CROOIJMANS, R.P.M.A.; VAN DER POEL, J.J.; VEENENDAAL, A. Whole genome scan for quantitative trait loci affecting body weight in chickens using a three generation design. Livestock Production Science, v.54, p.133-150, 1998.

VAN KAAM, J.B.C.H.M.; GROENEN, M.A.M.; BOVENHUIS, H.; VEENENDAAL, A.; VEREIJKEN, A.L.J.; VAN ARENDONK, J.A.M. Whole genome scan in chickens for quantitative trait loci affecting growth and feed efficiency. Poultry Science, v.78, p.15-23, 1999a.

VAN KAAM, J.B.C.H.M.; GROENEN, M.A.M.; BOVENHUIS, H.; VEENENDAAL, A.; VEREIJKEN, A.L.J.; VAN ARENDONK, J.A.M. Whole genome scan in chickens for quantitative trait loci affecting carcass traits. Poultry Science, v.78, p.1091-1099, 1999b.

VISSCHER, P.M.; THOMPSON, R.; HALEY, C.S. Confidence intervals in QTL mapping by bootstrapping. Genetics, v.143, p.1013-1020, 1996.

VOORRIPS, E.R. MapChart: software for the graphical presentation of linkage maps and QTLs. The Journal of Heredity, v.93, p.1-2, 2002.

WALLING, G.A.; ARCHIBALD, A.L.; CATTERMOLE, J.A.; DOWNING, A.C.; FINLAYSON, H.A.; NICHOLSON, D.; VISSCHER, P.M.; WALKER, C.A.; HALEY, C.S. Mapping of quantitative trait loci on porcine chromosome 4. Animal Genetics, v.29, p.415-424, 1998.

WEIR, B.S. Genetic data analysis II. Sunderland: Sinauer Associates, 1996. 445p.

WELLER, J.I.; WIGGANS, G.R.; VANRADEN, P.M.; RON,M. Application of a canonical transformation to detection of quantitative trait loci with the aid of genetic markers in a multi-trait experiment. Theoretical and Applied Genetics,.v.92, p.998-1002, 1996. 
YONASH, N; BACON, L.D.; WITTER, R.L.; CHENG, H.H. High resolution mapping and identification of new quantitative trait loci (QTL) affecting susceptibility to Marek's disease. Animal Genetics, v.30, p.126-135, 1999.

YONASH, N.; CHENG, H.H.; HILLEL, J.;HELLER, D.E.; CAHANER, A. DNA microsatellites linked to quantitative trait loci affecting antibody response and survival rate in meat-type chickens. Poultry Science, v.80, p.22-28, 2001.

YUNIS, R.; HELLER, E.D.; HILLEL, J.; CAHANER, A. Microsatellite markers associated with quantitative trait loci controlling antibody response to Escherichia coli and Salmonella enteritidis in young broilers. Animal Genetics, v.33, p.407-414, 2002.

ZHU, J.J.; LILLEHOJ, H.S.; CHENG, H.H.; POLLOCK, D.; SADJADI, M. e EMARA, M.G. Screening for highly heterozygous chickens in outbred commercial broiler lines to increase detection power for mapping quantitative trait loci. Poultry Science, v.80, p.6-12, 2001.

ZHU, J.J.; LILLEHOJ, H.S.; ALLEN, P.C.; VAN TASSEL, C.P.; SONSTEGARD, T.S.; CHENG, H.H.; POLLOCK, D.; SADJADI, M.; MIN, W.; EMARA, M.G. Mapping quantitative trait loci associated whit resistance to coccidiosis and growth. Poultry Science, v.82, p.9-16, 2003. 